Prepared in cooperation with the National Park Service

\title{
Hydrology and Geomorphology of the Taiya River Near the West Creek Tributary, Southeast Alaska
}

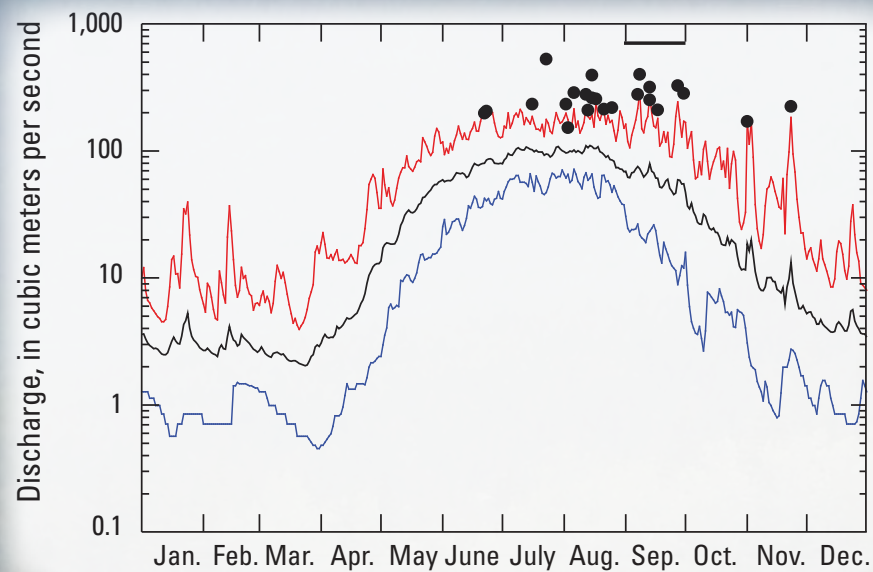

Scientific Investigations Report 2020-5059

U.S. Department of the Interior

U.S. Geological Survey 
Cover:

Background image: Midriver view of the Taiya River downstream from the Dyea Road bridge and upstream from the historical Dyea downtown area, looking downstream, Alaska (photograph by Janet Curran, U.S. Geological Survey, August 30, 2017).

Inset images, left to right: Hydrograph showing maximum, mean, and minimum daily discharge and peak discharge for period of record for U.S. Geological Survey streamgage on Taiya River, Alaska; relative elevation model of Taiya River main stem valley bottom for 2003 conditions, Alaska. 


\section{Hydrology and Geomorphology of the Taiya River Near the West Creek Tributary, Southeast Alaska}

By Janet H. Curran

Prepared in cooperation with the National Park Service

Scientific Investigations Report 2020-5059 


\title{
U.S. Department of the Interior DAVID BERNHARDT, Secretary
}

\author{
U.S. Geological Survey \\ James F. Reilly II, Director
}

U.S. Geological Survey, Reston, Virginia: 2020

For more information on the USGS - the Federal source for science about the Earth, its natural and living resources, natural hazards, and the environment-visit https://www.usgs.gov or call 1-888-ASK-USGS.

For an overview of USGS information products, including maps, imagery, and publications, visit https://store.usgs.gov.

Any use of trade, firm, or product names is for descriptive purposes only and does not imply endorsement by the U.S. Government.

Although this information product, for the most part, is in the public domain, it also may contain copyrighted materials as noted in the text. Permission to reproduce copyrighted items must be secured from the copyright owner.

Suggested citation:

Curran, J.H., 2020, Hydrology and geomorphology of the Taiya River near the West Creek Tributary, southeast Alaska: U.S. Geological Survey Scientific Investigations Report 2020-5059, 57 p., https://doi.org/10.3133/sir20205059.

Associated data for this publication:

Curran, J.H., 2020, Geomorphic surface and channel boundaries for the lower 7.5 kilometers of the Taiya River Valley, southeast Alaska, 2018: U.S. Geological Survey data release, https://doi.org/10.5066/P9XP1SE7.

ISSN 2328-0328 


\section{Acknowledgments}

The staff of the National Park Service graciously facilitated field access and provided access to geospatial data. Jami Belt of the National Park Service provided significant project coordination and field assistance. Rob Schenkert of the U.S. Geological Survey (USGS) and Devon Burton of the National Park Service (NPS) assisted with field activities. This project benefitted from discussions with Jami Belt, Karl Gurcke, Dave Schirokauer, and Paul Burger of the NPS and Robin Beebee, Jim O'Connor, and Louis Sass of the USGS. Joel Cusick of the NPS assisted with geospatial data acquisition. Karl Gurcke facilitated access to historical photographs and reports from the archives of the Klondike Gold Rush National Historical Park.

\section{Contents}

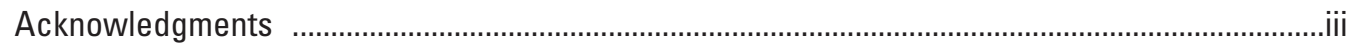

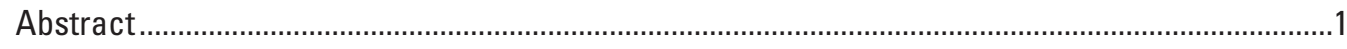

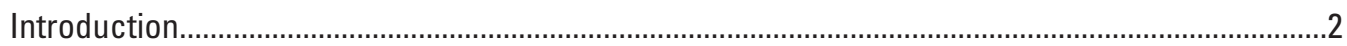

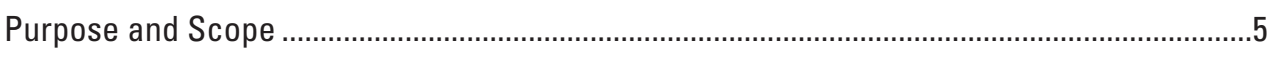

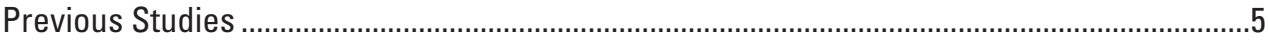

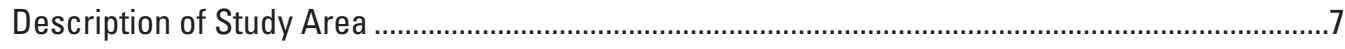

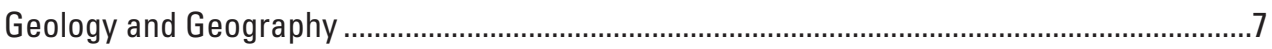

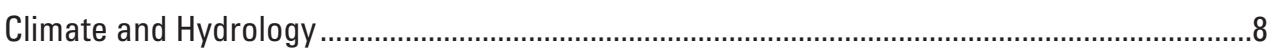

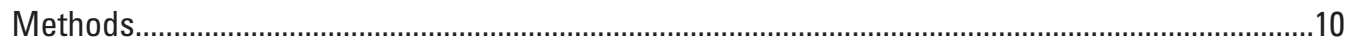

Streamflow Data and Flood History Compilation....................................................................10

Discrete Suspended Sediment Data Collection .....................................................................11

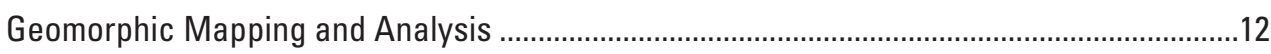

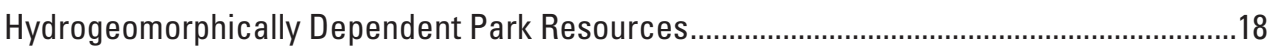

Surface-Water Hydrology and Suspended Sediment ...............................................................18

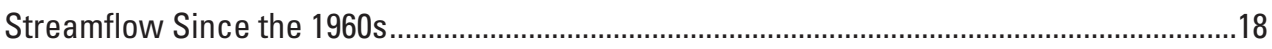

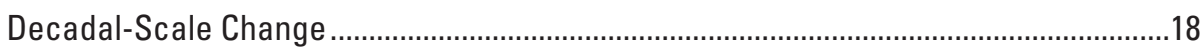

Comparisons Between West Creek and Taiya River Discharge ......................................20

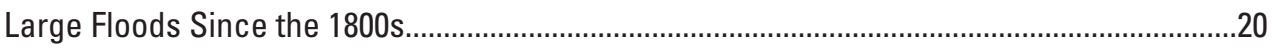

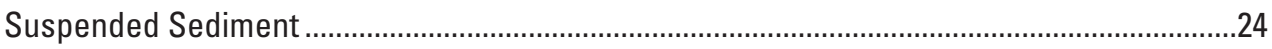

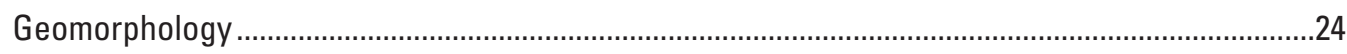

Valley and Main Stem Channel Geomorphology .............................................................28

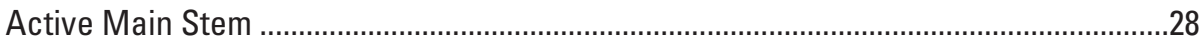

Abandoned Fluvial Surfaces ............................................................................................

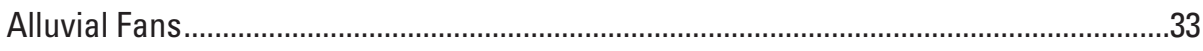

Emergent Tidal Flats ...........................................................................................

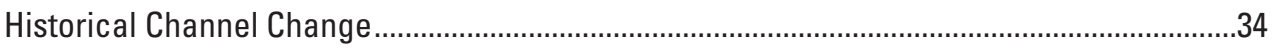

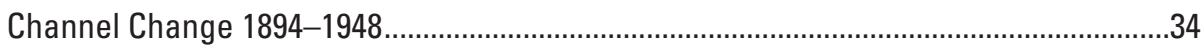

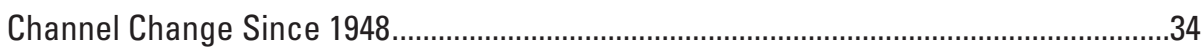

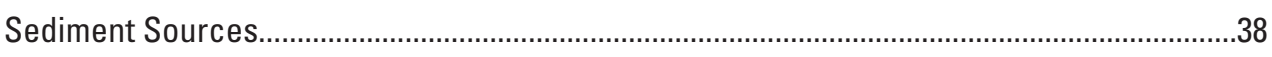

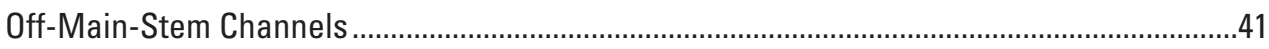


Selected Hydrogeomorphically Dependent Resources ................................................................46

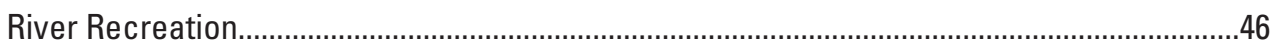

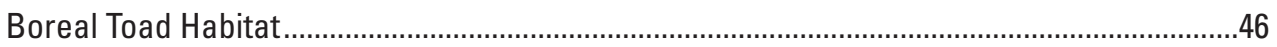

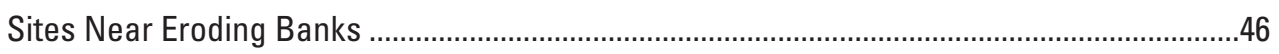

Hydrogeomorphic Implications for Taiya River Resources ............................................................48

Evolution of Valley Bottom Surfaces and Channels...........................................................48

Streamflow and Sediment Timing and Seasonality ..............................................................50

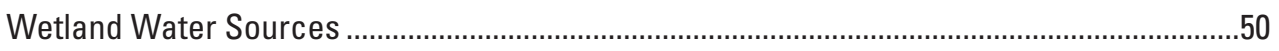

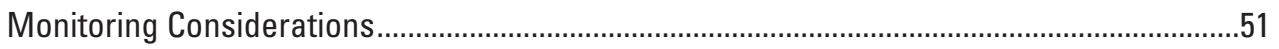

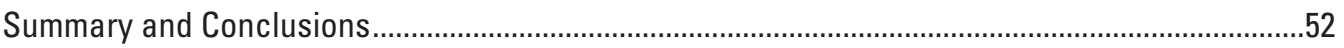

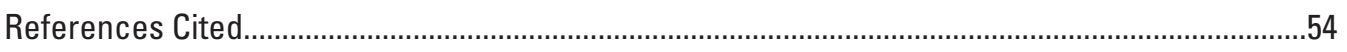

Appendix 1. Geographic Information System Digital Files ........................................................57

\section{Figures}

1. Taiya River Basin and Lynn Canal, southeast Alaska, and Taiya River Basin and West Creek subbasin drainage basins, Klondike Gold Rush National Historical Park, mapping area, and selected streamgages, southeast Alaska.................................

2. Main stem Taiya River valley bottom and mapping area, Alaska ........................................6

3. Elevation and locations of features within the most developed part of the main stem Taiya River valley bottom, Alaska.

4. Dates for periods of daily discharge and peak discharge record, and dates of suspended sediment sampling, through water year 2019 at U.S. Geological Survey streamgages at West Creek and the Taiya River, Alaska.

5. Hydrographs showing maximum, mean, and minimum daily discharge and peak discharge during the period of record for U.S. Geological Survey streamgages on West Creek and Taiya River, Alaska..

6. Examples of geospatial products used for geomorphic mapping and an example completed geomorphic map for a section of the mapping area in the Taiya River valley, Alaska.

7. Mean annual discharge for each year through water year 2017 at U.S. Geological Survey streamgages at West Creek and Taiya River, Alaska

8. Mean daily discharge for the Taiya River at U.S. Geological Survey streamgage 15056210, Alaska, water years 1970-77 and water years 2004-17

9. Normalized mean daily discharge for West Creek at U.S. Geological Survey streamgage 15056200 and the Taiya River at USGS streamgage 15056210, Alaska, for the common period of record, water years 1970-77

10. Orthophotograph and oblique aerial photographs showing 2002 West Creek glacial lake outburst flood setting and effects

11. Historical aerial photograph looking south down the Taiya River, Alaska main stem taken in 1894 by J.J. McArthur for an international boundary survey.

12. Discrete suspended sediment concentration in relation to measured discharge at U.S. Geological Survey streamgages West Creek and Taiya River, Alaska, during periods of record.

13. Discrete suspended sediment concentration by month and day of sampling for U.S. Geological Survey streamgages West Creek and Taiya River Alaska, during periods of record. 
14. Relative elevation model of the Taiya River main stem valley bottom showing height above the water surface of Taiya River and Nourse River, Alaska, for 2003 conditions.

15. Combined geomorphic map showing geomorphic surfaces by formative process and off-main-stem channels of the lower 7.5 kilometers of the Taiya River valley bottom, Alaska...

16. Stream longitudinal profile for the Taiya River and major tributaries within the Taiya River main stem valley, Alaska, from 2003 lidar data and active Taiya River channel and valley bottom widths within the mapping area .

17. Geomorphic map of the lower 7.5 kilometers of the Taiya River valley bottom, Alaska, showing geomorphic surfaces by formative process and relative age. .31

18. Photographs of West Creek and Taiya River features, Alaska .......................................32

19. Photographs from Klondike Gold Rush National Historical Park photo station $\mathrm{CH}-14$ looking west toward West Creek from AB Mountain above the Taiya River valley, Alaska

20. Changes to the active main stem of the Taiya River between 1948 and 2018 near the Dyea townsite, Alaska.

21. Aerial photographs showing changes to the confluence of West Creek and the Taiya River, Alaska, 1948-2014. A, 1948, black and white

22. Changes to slough entrance conditions and constraints on slough flow path at valley kilometers 6.0-7.5, Taiya River, Alaska

23. Incision inferred from changes in stage for a given discharge at U.S. Geological Survey streamgage at Taiya River, Alaska

24. Off-main-stem channels in the lower 7.5 kilometers of the Taiya River valley bottom, Alaska, and amphibian monitoring sites maintained by the National Park Service.

25. Photographs of examples of off-main-stem channels in the Taiya River valley bottom, Alaska . .45

26. Photograph showing large woody debris in mid-channel, Taiya River, Alaska ..............47

27. Photographs showing a boreal toad adult and metamorphs in wetlands formed in abandoned sloughs of the Taiya River, Alaska

28. Mean monthly discharge during April, May, and June, 2012-16, in relation to mean monthly temperature for the Taiya River at U.S. Geological Survey streamgage 15056210, Alaska. 


\section{Tables}

1. Basin characteristics for drainage basins at USGS streamgages at West Creek (15056200) and the Taiya River (15056210), Alaska

2. Data sources used for mapping and interpretation of geomorphic features in the Taiya River Basin, Alaska

3. Descriptions of geomorphic surfaces mapped for the lower 7.5 kilometers of the Taiya River valley bottom, Alaska

4. Definitions of attributes for off-main-stem channels mapped for the lower 7.5 kilometers of the Taiya River valley bottom, Alaska

5. Differences in mean monthly and mean annual discharge between water years 1970-77 and water years 2004-17 for the Taiya River, Alaska, at U.S. Geological Survey streamgage 15056210

6. Attributes of off-main-stem channels in the lower 7.5 kilometers of the Taiya River valley bottom, Alaska

\section{Conversion Factors}

International System of Units to U.S. customary units

\begin{tabular}{|c|c|c|}
\hline Multiply & By & To obtain \\
\hline \multicolumn{3}{|c|}{ Length } \\
\hline millimeter $(\mathrm{mm})$ & 0.03937 & inch (in.) \\
\hline meter $(\mathrm{m})$ & 3.281 & foot $(\mathrm{ft})$ \\
\hline kilometer $(\mathrm{km})$ & 0.6214 & mile (mi) \\
\hline \multicolumn{3}{|c|}{ Area } \\
\hline square kilometer $\left(\mathrm{km}^{2}\right)$ & 247.1 & acre \\
\hline square kilometer $\left(\mathrm{km}^{2}\right)$ & 0.3861 & square mile $\left(\mathrm{mi}^{2}\right)$ \\
\hline \multicolumn{3}{|c|}{ Volume } \\
\hline liter $(\mathrm{L})$ & 33.81402 & ounce, fluid (fl. oz) \\
\hline liter $(\mathrm{L})$ & 2.113 & pint (pt) \\
\hline liter (L) & 1.057 & quart (qt) \\
\hline liter (L) & 0.2642 & gallon (gal) \\
\hline cubic meter $\left(\mathrm{m}^{3}\right)$ & 264.2 & gallon (gal) \\
\hline cubic meter $\left(\mathrm{m}^{3}\right)$ & 0.0002642 & million gallons (Mgal) \\
\hline liter (L) & 61.02 & cubic inch $\left(\mathrm{in}^{3}\right)$ \\
\hline cubic meter $\left(\mathrm{m}^{3}\right)$ & 35.31 & cubic foot $\left(\mathrm{ft}^{3}\right)$ \\
\hline cubic meter $\left(\mathrm{m}^{3}\right)$ & 1.308 & cubic yard $\left(\mathrm{yd}^{3}\right)$ \\
\hline cubic meter $\left(\mathrm{m}^{3}\right)$ & 0.0008107 & acre-foot (acre-ft) \\
\hline \multicolumn{3}{|c|}{ Flow rate } \\
\hline cubic meter per second $\left(\mathrm{m}^{3} / \mathrm{s}\right)$ & 70.07 & acre-foot per day (acre-ft/d) \\
\hline meter per year $(\mathrm{m} / \mathrm{yr})$ & 3.281 & foot per year ft/yr) \\
\hline cubic meter per second $\left(\mathrm{m}^{3} / \mathrm{s}\right)$ & 35.31 & cubic foot per second $\left(\mathrm{ft}^{3} / \mathrm{s}\right)$ \\
\hline cubic meter per second $\left(\mathrm{m}^{3} / \mathrm{s}\right)$ & 22.83 & million gallons per day $(\mathrm{Mgal} / \mathrm{d})$ \\
\hline millimeter per year $(\mathrm{mm} / \mathrm{yr})$ & 0.03937 & inch per year (in/yr) \\
\hline
\end{tabular}


Temperature in degrees Celsius $\left({ }^{\circ} \mathrm{C}\right)$ may be converted to degrees Fahrenheit $\left({ }^{\circ} \mathrm{F}\right)$ as follows:

$$
{ }^{\circ} \mathrm{F}=\left(1.8 \times{ }^{\circ} \mathrm{C}\right)+32 \text {. }
$$

\section{Datums}

Vertical coordinate information is referenced to the North American Vertical Datum of 1988 (NAVD 88).

Horizontal coordinate information is referenced to the North American Datum of 1983 (NAD 83).

Elevation, as used in this report, refers to distance above the vertical datum.

\section{Supplemental Information}

Concentrations of chemical constituents in water are given in either milligrams per liter (mg/L) or micrograms per liter $(\mu \mathrm{g} / \mathrm{L})$.

\section{Abbreviations}

GIS Geographic Information System

IfSAR interferometric synthetic aperture radar

lidar light detection and ranging

NPS National Park Service

NTU nephelometric turbidity units

NWIS National Water Information System

KLGO Klondike Gold Rush National Historical Park

REM relative elevation model

USGS U.S. Geological Survey

VK valley kilometer

WY water year 
This page intentionally left blank. 


\title{
Hydrology and Geomorphology of the Taiya River Near the West Creek Tributary, Southeast Alaska
}

\author{
By Janet H. Curran
}

\section{Abstract}

The Taiya River flows through the Chilkoot Trail Unit of Klondike Gold Rush National Historical Park in southeast Alaska, which was founded to preserve cultural and historical resources and further understanding of natural processes active in the surrounding coastal-to-subarctic basin. Riverine processes exert an important influence on ecologically important boreal toad (Anaxryus boreas boreas), salmon [chum salmon (Oncorhynchus keta), pink salmon (O. gorbushca), and coho salmon (O. kisutch)], and eulachon (Thaleichthys pacificus) habitats, erosion of the historic ghost town of Dyea and other cultural and historical artifacts, and recreational opportunities in the lower 7.5 kilometers $(\mathrm{km})$ of the Taiya River valley bottom. Recurrent consideration of hydroelectric development in West Creek upstream of the park since the 1980s has included proposals for damming and diverting West Creek, which could alter the delivery of water and sediment to this section of the Taiya River. To improve understanding of the hydrologic dependence of park resources for the purposes of guiding effective monitoring and conservation, this study, conducted by the U.S. Geological Survey in cooperation with the National Park Service, used a review of hydrologic data, collection of discrete suspended sediment data, geomorphic mapping, and analysis of historical aerial and ground photographs in a reconnaissance of formative geomorphic processes and hydrologic conditions in the lower $7.5 \mathrm{~km}$ of the Taiya River valley bottom.

Streamflow and suspended sediment data collected at the U.S. Geological Survey streamgages on the Taiya River and West Creek, combined with historical data, document conditions consistent with streams draining strongly glacierized basins in Alaska. Suspended sediment concentrations from samples collected concurrently over six varying flow levels during 2017-18 ranged from 6 to 284 milligrams per liter (mg/L) for the Taiya River and 13 to $162 \mathrm{mg} / \mathrm{L}$ for West Creek, which are similar to or slightly higher than historical values. For the common period of record (1970-77), correlation of daily mean discharge between the two streams was strongest (Pearson's $r=0.97$ ) during the prolonged May-October high-flow season and weakest $(r=0.90)$ during the November-April low-flow season, when West Creek daily mean discharge was proportionally higher. For the Taiya River, streamflow data compared between the available periods of record (1970-77 and 2004-17) showed no decadalscale patterns in mean annual discharge but did show a shift toward an earlier spring snowmelt pulse. Notable flooding in the Taiya River Basin includes glacial lake outburst floods from the Nourse River valley prior to and during the 1897-98 Gold Rush, a 2002 glacial lake outburst flood from the West Creek valley, and a 1967 rainfall-generated flood.

Geomorphic mapping identified four categories of surfaces in the valley bottom - active main stem, abandoned main stem, alluvial fans, and emergent tidal surfaces. Using the maps, main-stem surfaces were subdivided into age categories to identify channel migration patterns from prior to 1940 s to 2018. The valley bottom is dominated by active or abandoned channels of the Taiya River except at the extensive low-angle West Creek fan. The active main stem presently supports a mostly single-thread channel with bars and a few sloughs, but the channel actively moved and sometimes was braided within multiple, wider unvegetated corridors in 1894 and earlier. An inventory of 29 off-main-stem channels identified for the study indicates that abandoned main stem channels provide local topographic lows that can intercept groundwater or sustain tributary flow, facilitating the formation of most nonestuarine wetlands in the valley and sustaining important boreal toad breeding habitat.

Within the active main stem corridor, the channel has episodically built and reworked meanders and bars, eroding more than one-half of the historic Dyea townsite, in response to glacially controlled delivery of water and sediment, flooding, inputs from West Creek, local features including large woody debris and beaver dams, and rapid uplift from isostatic rebound. West Creek has constructed a large, persistent fan, provoked kilometer-scale Taiya River channel change near the confluence, constructively added to high-season streamflow that affects Taiya River channel migration capacity, disproportionately contributed early-season streamflow, and possibly contributed to groundwater levels in the valley bottom. The progressive narrowing and stability of the main stem corridor, possibly a result of reduction in the magnitude or frequency of glacial lake outburst floods or glacial sediment delivery to streams, indicates less active future reworking of abandoned main-stem surfaces or regeneration of wetland features. The 
fluvial history of the Taiya River valley bottom collectively indicates continued channel change within a limited corridor, relative stability in wetland locations but uncertainty in stability of groundwater supply to them, and channel incision and extension in response to uplift.

\section{Introduction}

The Taiya River drains a 481-square-kilometer $\left(\mathrm{km}^{2}\right)$ basin that extends from glacier-rich 2,500-meter peaks in the Coast Mountains of southeastern Alaska to sea level at the head of Taiya Inlet, about 3 kilometers $(\mathrm{km})$ northeast of Skagway, Alaska (fig. 1). The main stem Taiya River parallels the historic Chilkoot Trail in a $1 \mathrm{~km}$-wide, relatively flat-bottomed, steep-sided valley for about $14 \mathrm{~km}$ upstream from the river's estuarine mouth. Much of the Taiya River and its valley bottom lie within the Chilkoot Trail Unit of Klondike Gold Rush National Historical Park, referred to by the National Park Service (NPS) acronym KLGO (fig. 1B). The Chilkoot Trail Unit includes NPS, municipal, State, and private lands. All but a small reach of West Creek, a major tributary that drains 23 percent of the Taiya River Basin and enters the valley bottom $4.5 \mathrm{~km}$ upstream from the mouth, lies outside KLGO boundaries and is managed by the Municipality of Skagway.

For effective development of management strategies that consider the natural processes of the Taiya River valley and the potential changes with land use or climate variability, NPS expressed a need for information regarding river hydrology (Bernatz and others, 2011). Mixed land ownership of the Taiya River Basin presents a need for NPS to consider the effects of land management by others on a major stream in a national park. Hydroelectric proponents have twice proposed damming and diverting West Creek for a hydroelectric facility, once in the 1980s (R.W. Beck and Associates, Inc., 1982) and again in a proposal (Alaska Power Company, 2014) withdrawn in 2017. Other uses considered for the West Creek basin have included recreational, residential, logging, mining, and municipal activities (Municipality of Skagway, 2014). The limited nonmountainous land available near Skagway coupled with the accessibility, geography, and less-restrictive land ownership status of the West Creek valley indicates that future proposals for land-use changes are likely. The hydrogeomorphic effects on the Taiya River and KLGO resources from potential hydrologic changes to West Creek are not well understood.

The Chilkoot Trail and former townsite of Dyea, made famous during the late 1800s Gold Rush, are a National Historic Landmark that provide well-known KLGO historical, recreational, and cultural resources in the Taiya River valley. The KLGO foundation statement acknowledges these resources but also focuses on fostering "an understanding of the physical and biological processes and associated unique flora and fauna" of the northern Lynn Canal, a fjord that cuts deeply into the Coast Mountains (fig. $1 A$ ) and forces the convergence of subarctic, alpine, coastal, and boreal ecosystems over a short distance. Taiya Inlet, at the mouth of the Taiya River, forms the northernmost and most inland of several inlets at the head of Lynn Canal. The species and habitats of the Taiya River valley are thus of inherent importance to the NPS, charged with conservation of cultural and historical resources and the natural setting within which they occur (Bernatz and others, 2011).

The Taiya River valley bottom is largely filled with active and abandoned channels, alluvial fans, and estuarine surfaces. Estuarine intertidal areas, wetlands, and clearwater side channels (valley bottom channels conveying nonturbid tributary flow or groundwater discharge to the main stem) in the valley bottom provide habitats for ecologically or economically important species including the boreal toad (Anaxryus boreas boreas), three species of Pacific salmon [chum salmon (Oncorhynchus keta), pink salmon (O. gorbushca), and coho salmon (O. kisutch)], and eulachon (Thaleichthys pacificus) (Arimitsu and others, 2003; Hood and others, 2006). Cultural resources along Taiya River banks include archeological sites and culturally significant artifacts, and modern uses of the river include recreational activities, such as rafting. The Taiya River is listed on the Nationwide Rivers Inventory (NRI), a compilation of free-flowing rivers possessing features deemed as outstandingly remarkable natural or cultural values (National Park Service, 2017), making the stream eligible for designation as a Wild and Scenic River. The historical significance of the Taiya River and its ecological importance as a corridor motivated this listing, which mandates that Federal agencies seek to avoid impacts that would adversely affect those values.

To address current management needs and guide planning, NPS sought to understand the dependence of existing biological, cultural, and recreational resources of the Taiya River valley on hydrologic and geomorphic conditions. As part of the Natural Resources Preservation Program, a U.S. Geological Survey (USGS) -NPS science partnership, the USGS, in cooperation with NPS, conducted a reconnaissance study of important hydrologic and geomorphic processes in the lower $7.5 \mathrm{~km}$ of the Taiya River valley bottom, encompassing the West Creek confluence. 


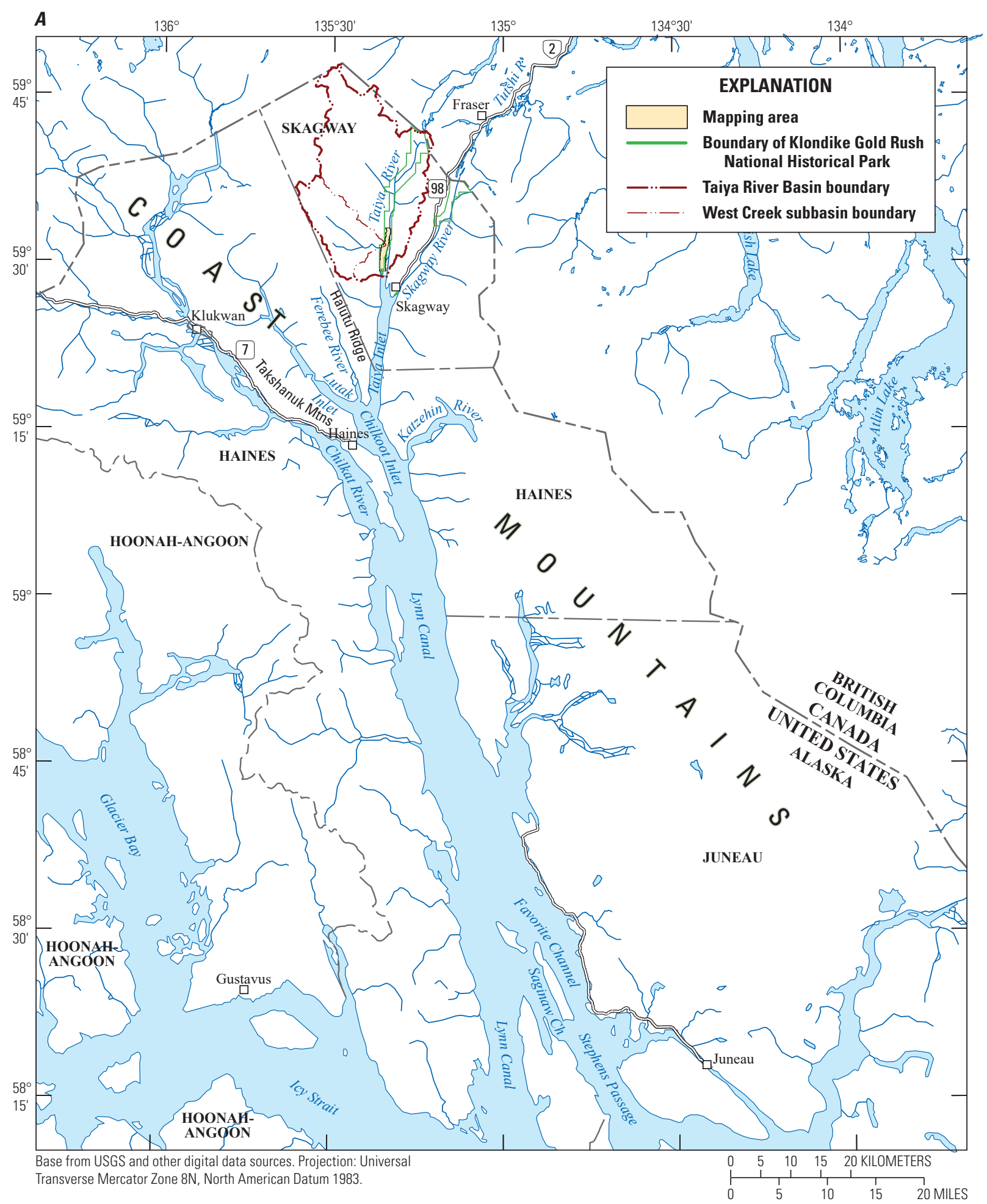

Figure 1. A, Taiya River Basin and Lynn Canal, southeast Alaska, and, B, Taiya River Basin and West Creek subbasin drainage basins, Klondike Gold Rush National Historical Park, mapping area, and selected streamgages, southeast Alaska. [USGS, U.S. Geological Survey] 


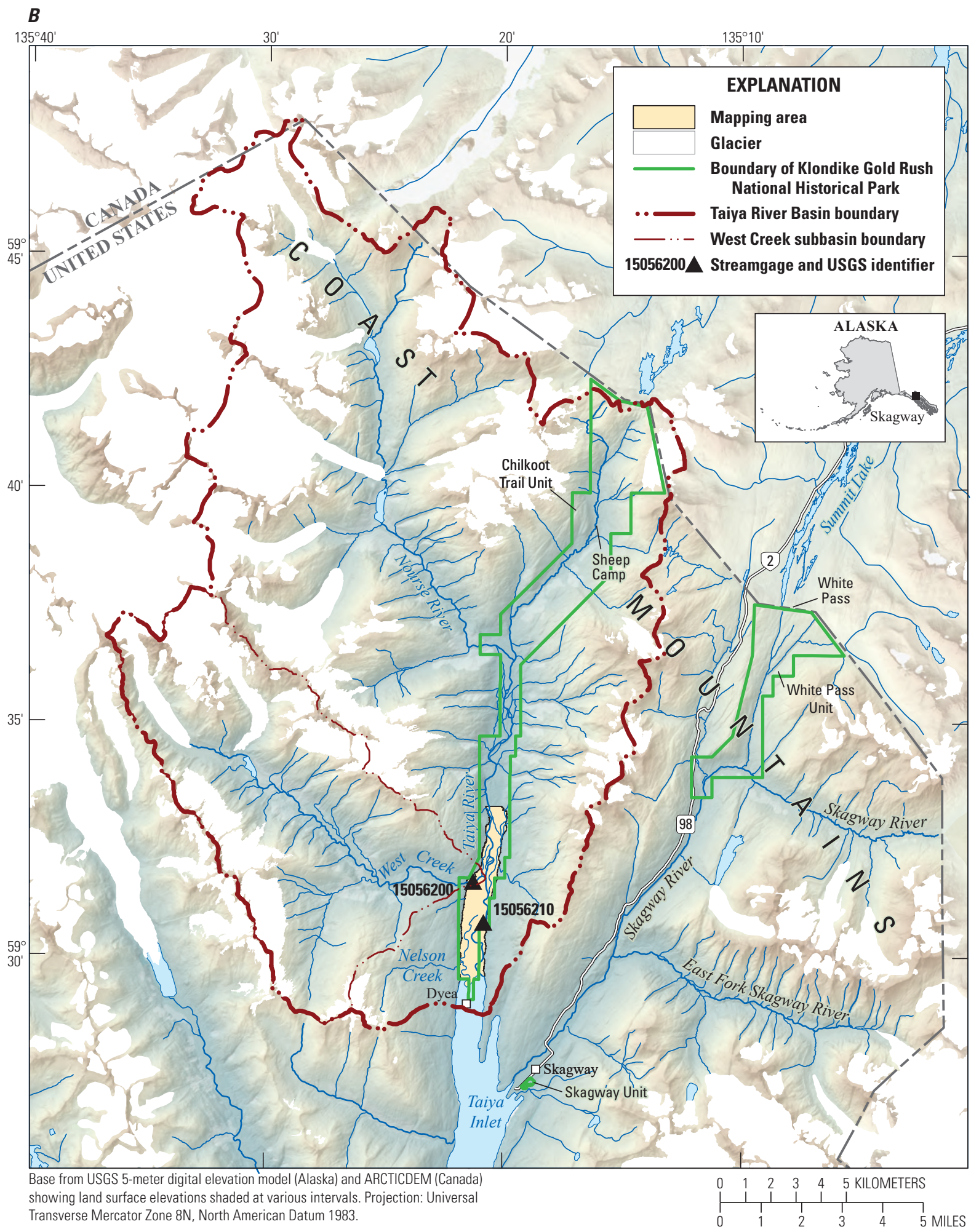

Figure 1.-Continued 


\section{Purpose and Scope}

This report presents the results of a reconnaissance study of hydrologic and geomorphic conditions for a mapping area consisting of the lower $7.5 \mathrm{~km}$ of the Taiya River valley bottom. The full study area consists of the Taiya River Basin, especially the upper $6.5 \mathrm{~km}$ of the main stem valley bottom and the tributary valleys of West Creek, Nourse River, and the upper Taiya River, as needed to provide context for more detailed assessment of the mapping area. The objectives of the study were to assess existing conditions in the mapping area as of 2017-19 (depending on the condition considered) in the context of hydrologic and geomorphic history and consider the potential effects of water and sediment discharge from the West Creek tributary to inform NPS resource management. This study drew from existing streamflow and sediment data, aerial imagery, and high-resolution light detection and ranging (lidar) topographic data, supplemented with collection of suspended sediment data and ground observations of landforms and processes in the mapping area. Study findings build on or expand findings from previous studies (for example, Bernatz and others, 2011). This report documents important physical processes and conditions, including the timing and amount of water and sediment delivery, the geomorphic history of the West Creek fan and Taiya River channels, and the distribution and hydrologic connectivity of channel forms.

\section{Previous Studies}

The USGS has intermittently monitored streamflow, water quality, and sediment characteristics at USGS streamgages on West Creek (15056200) and Taiya River (15056210) downstream of West Creek (figs. 1 and 2) since the 1960s. In addition, the Southeast Alaska Network Freshwater (SEAN) Water Quality Monitoring Program has monitored water-quality characteristics, including turbidity, at the USGS Taiya River streamgage since 2011 (Sergeant and Johnson, 2018; data available at https://irma.nps.gov/DataStore/ Reference/Profile/2182282).

The KLGO Natural Resource Condition Assessment completed in 2011 (Bernatz and others, 2011) presents a systematic and comprehensive summary of KLGO natural resources, including hydrologic analyses of data through 2009. Hydrogeomorphically relevant KLGO resources include riparian flora, boreal toads, wetlands, water quality, hydrology, proglacial lakes, and ice cover.
Glacial lake outburst flooding associated with dynamic glacier conditions in the headwater valleys of the Taiya River is discussed in an informal exploration of evidence for preGold Rush glacial lake outburst flooding (Streveler, 1995) and an informal geohazards report conducted as part of the Geoscientist-in-Parks program (Capps, 2004) that discusses Gold-Rush era outburst floods and a 2002 outburst flood in West Creek.

Mapping for a reconnaissance ecological inventory of KLGO (Paustian and others, 1994) established a general framework for understanding Taiya River hydrology and geomorphology. The Taiya River main stem valley bottom was mapped as an extensive flood plain unit consisting largely of glacial outwash terraces; a fan unit including four large, high-angle tributary fans near Finnegan's Point (fig. 2); and an uplifted estuary unit near the river mouth that includes river delta and glaciomarine sediments. A channel-type assessment for the main stem and many smaller streams incorporated channel morphology, channel hydraulics, aquatic habitat, and fish species present to categorize stream segments. Individual main stem segments are described as meandering to braided. Abandoned channels were mapped as palustrine or noted to contain clearwater side channels conveying discharge from small tributaries or shallow flood-plain aquifers. A limitation of this mapping is that specific channel locations were based on USGS topographic maps, which did not match many main stem channel patterns at the time. An additional mapping effort (Bosworth, 2000) produced the most recent KLGO wetland map, which extended from the West Creek confluence downstream and primarily relied on the National Wetland Inventory.

Subsequent localized studies addressed bank erosion and channel processes near Dyea in detail (Inglis and Pranger, 2002; Richards and others, 2017). Much of the Gold Rush era Dyea townsite, including the Dyea town cemetery containing remains of native and nonnative individuals, has been undermined by bank erosion and bank collapse and swept away by the river. Inglis and Pranger (2002) provide a narrative of river migration observed in historical ground photographs from the 1890s and 1920s and aerial photographs from the 1920s, 1948, 1970s, and 1990s, characterize Taiya River channel patterns as having decadal-scale periods of relative lateral stability broken by annual-scale channel change in discrete locations, and describe the ongoing isostatic rebound of the region as a likely driver of changing tideline location and land uplift/river incision. An NPS bank erosion monitoring report (Richards and others, 2017) notes that a period of erosion in the 1970s prompted the relocation of some human remains and archeological artifacts. 

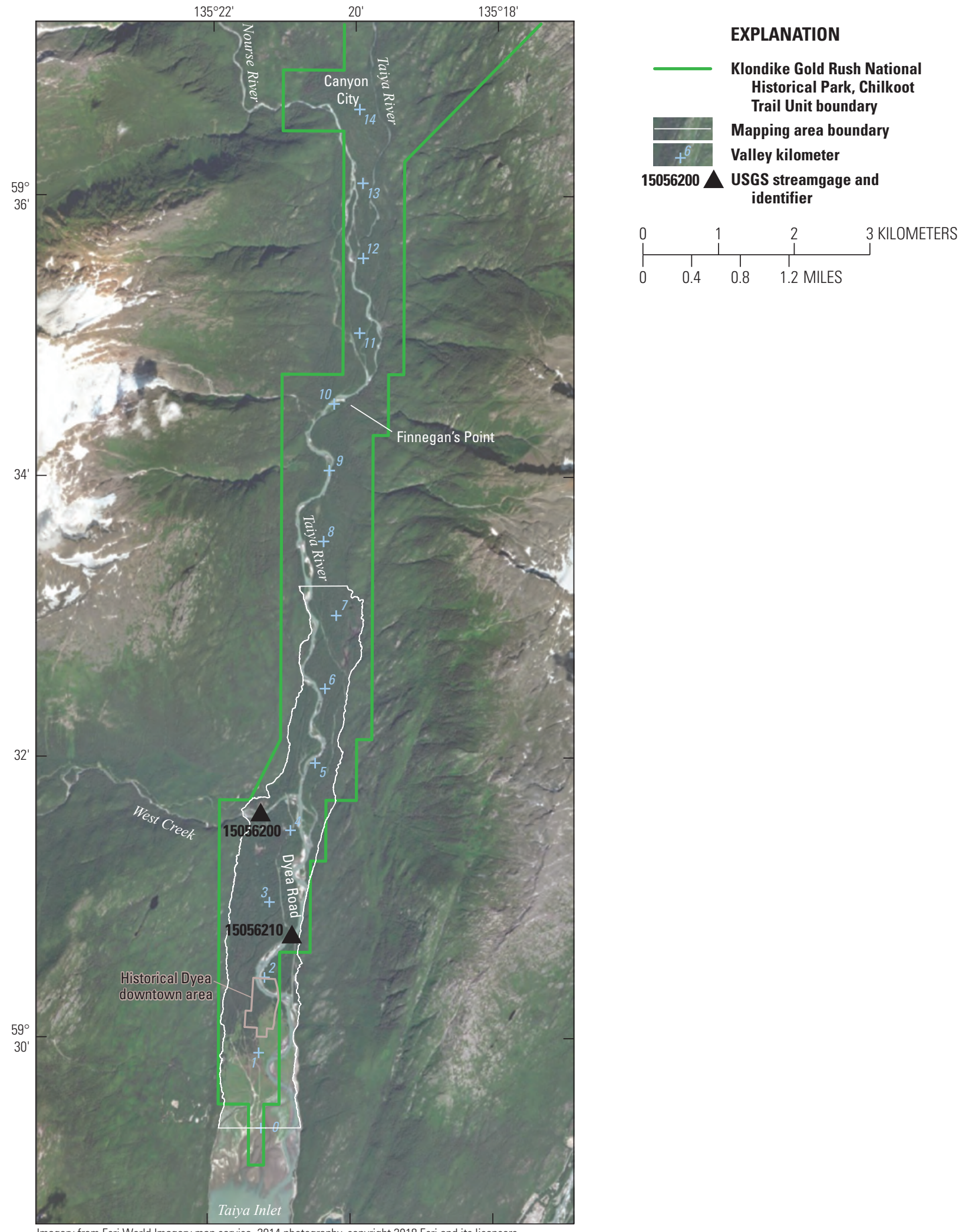

Imagery from Esri World Imagery map service, 2014 photography, copyright 2018 Esri and its licensors. Universal Transverse Mercator Zone 8N, North American Datum 1983.

Figure 2. Main stem Taiya River valley bottom and mapping area, Alaska. [USGS, U.S. Geological Survey] 


\section{Description of Study Area}

The Taiya River Basin is mapped in the national Watershed Boundary Dataset (U.S. Geological Survey and U.S. Department of Agriculture, Natural Resources Conservation Service, 2013) as Taiya River Basin $\left(162 \mathrm{~km}^{2}\right)$ and two tributary basins, West Creek $\left(112 \mathrm{~km}^{2}\right)$ and Nourse River $\left(207 \mathrm{~km}^{2}\right.$; fig. $1 B$ ). However, because the Nourse River is much larger and longer (more than $17 \mathrm{~km}$ ) than the upper part of the Taiya River (11 km upstream of the Nourse River confluence) and constitutes the hydrologic headwaters of the basin, this report considers the river system to be the 14-km-long Taiya River main stem reach between the river mouth and the Nourse River confluence and three tributaries - West Creek, Nourse River, and upper Taiya River. The main stem and upper Taiya River total $25 \mathrm{~km}$ in length.

During 2013-17, more than 900,000 people visited KLGO annually (https://irma.nps.gov/Stats/, accessed August 9, 2018). Although the Skagway Unit near cruise ship docks is a primary draw, recreational resources of the Taiya River valley are also considered an amenity and a local economic driver. The river is part of the scenic experience of the lower Taiya River valley, which has become a popular destination for readily accessible bird and wildlife viewing, hiking, biking, horseback riding, and camping in addition to visitation of KLGO historical sites. The gentle (nonwhitewater) reach of about the lower $5 \mathrm{~km}$ of the Taiya River supports guided rafting excursions by several tour operators, a primary commercial use of the river since the 1980s (Buzzell, 2004).

Because the mouth of the Taiya River is an indistinct estuarine environment, locations within the study area are given as arbitrary valley kilometers (VK) originating at the downstream end of the mapping area, which is an arbitrary point at the tip of the downstream-most surface not inundated by mean higher high tide (the average of the higher of the two daily high tides), and extending up the middle of the valley to the end of the valley bottom at VK 14. Although mapping was extended upstream to VK 7.4 to encompass a locally complex channel system, the text generalizes discussion to VK 7.5. Most locations are given to the nearest $0.5 \mathrm{VK}$ to indicate a general location for orientation rather than describing specific feature extents. For the purposes of a stream longitudinal profile along the main stem river bottom, locations along the channel centerline are given as river kilometers upstream of the same arbitrary mapping area end point. The centerline was digitized along the center of the main channel as shown in a summer 2003 orthophotograph, using spring 2003 lidar data assumed to represent the same flow path as a guide where vegetation or shadowing obscured channels.

\section{Geology and Geography}

The Taiya River Basin is part of the Coast Mountains batholith, an extensive band of plutonic and metamorphic rocks along the west coast of northern North America. The basin is largely underlain by Tertiary granodiorite (Wilson and others, 2015). A fault interpreted as a splay of the Chatham Strait fault (Gehrels, 2000) extends through Taiya Inlet and the main stem Taiya River valley. Pleistocene glaciers occupied southeast Alaska, flowing out through pre-existing valleys including Lynn Canal (Kaufman and others, 2011). Presentday glaciers cap taller peaks across the basin and merge with extensive glaciers along the western side of the basin (fig. $1 B$ ), collectively covering 29 percent of the Taiya River Basin (table 1). The West Creek subbasin has physical characteristics and glacier coverage similar to the Taiya River (fig. 1, table 1). The basin characteristics in table 1 are for basins originating at the USGS streamgages and were developed from methods described in Curran and others (2016). The streamgage drainage areas represent 99 percent and 96 percent of the West Creek and Taiya River Basins, respectively, and no major hydrologic changes occurred between the streamgage and the basin mouth, such that streamgage basin characteristics can be considered representative of the entire basins.

Isostatic rebound from the release of depression by thick glaciers has generated ongoing rapid uplift relative to sea level across southeast Alaska. Uplift rates are estimated to range from 16 millimeters per year $(\mathrm{mm} / \mathrm{yr})$ near the basin mouth to $14 \mathrm{~mm} / \mathrm{yr}$ in the northeastern part of the basin (Larsen and others, 2005; Bernatz and others, 2011), generating almost $2 \mathrm{~m}$ of uplift since the Gold Rush. In 2003, the historical high-tide line located along the southern edge of the Dyea townsite (fig. 2) was more than $500 \mathrm{~m}$ inland from the location of the mean higher high-water elevation of 5.1 $m$ for tidal epoch 2007-11. River response to uplift in southeast Alaska has included incision when base-level change translated into increased channel slope, which increases the ability of the river to scour its bed (for example, Mendenhall River, Neal and Host (1999)). Base level for the Taiya River is sea level and can be thought of as lowering relative to the river, although technically the land surface is rising. Sediment deposited at the river mouth has created a gently sloping delta. As this is uplifted, the river is extended, which could at least partly counter the effect of base-level change on channel slope.

Major gravel-bedded streams extend up the basin's three prominent, long valleys to glaciers in the Nourse and West Creek subbasins and to the low, glacier-free Chilkoot Pass $(1,100 \mathrm{~m})$ at the head of the Taiya River. The Nourse River valley contains a series of tributary glaciers, associated lakes, and intervening stream segments (fig. $1 B$ ) and drains through a bedrock gorge near the mouth. Bedrock controls the planform and stability of the lowermost $3.5 \mathrm{~km}$ of West Creek, including two narrow gorge sections. Farther upstream along West Creek, a 5.5-km-long sediment-filled valley is flanked by mostly untrimmed alluvial fans and holds a narrow active stream corridor and adjacent extensive wetland areas lacking major topographic channel scars. Throughout most of the sediment-filled Taiya River valley bottom, channel scars preserve a history of channel mobility, but 2019 Taiya River channels lack the braided character common to many glacial streams and are instead relatively stable, single-channel systems. 
Table 1. Basin characteristics for drainage basins at USGS streamgages at West Creek (15056200) and the Taiya River (15056210), Alaska.

[Mean basin elevation: Elevations here are given in meters above NGVD of 1929. Abbreviations: km² , square kilometers; mm, millimeter; $\mathrm{m}$, meter]

\begin{tabular}{lcccccc}
\hline Stream & $\begin{array}{c}\text { Drainage } \\
\text { area }\left(\mathbf{k m}^{2}\right)\end{array}$ & $\begin{array}{c}\text { Mean annual } \\
\text { precipitation } \\
(\mathbf{m m})\end{array}$ & $\begin{array}{c}\text { Mean minimum } \\
\text { January temperature } \\
\text { (degrees Celsius) }\end{array}$ & $\begin{array}{c}\text { Mean maximum } \\
\text { July temperature } \\
\text { (degrees Celsius) }\end{array}$ & $\begin{array}{c}\text { Mean basin } \\
\text { elevation (m) }\end{array}$ & $\begin{array}{c}\text { Glacier } \\
\text { coverage } \\
\text { (percent of } \\
\text { basin) }\end{array}$ \\
\hline West Creek & 111 & 1,880 & -13 & 13 & 1,000 & 29 \\
Taiya River & 461 & 1,930 & -13 & 13 & 1,070 & 29 \\
\hline
\end{tabular}

During the Gold Rush era, the now abandoned Nelson Slough (fig. 3; VK 0-3.5) conveyed a substantial portion of the main stem flow and was known as West Branch Taiya River.

Although the Taiya River valley supported hundreds of residents and thousands of hopeful prospectors at Dyea and the Canyon City and Sheep Camp settlements along the Taiya River during the Gold Rush era, these settlements lasted only a few years before being reduced to ghost towns when alternate routes to gold fields opened. However, logging to supply power for steam locomotive engines for Chilkoot Trail aerial tramways substantially removed trees from the Canyon City area at the head of the Taiya River main stem (fig. 2) in 188899 (Karl Gurcke, National Park Service, oral commun., 2017), and a sawmill operated in the northern part of the mapping area from 1948-56 (F. Norris, National Park Service, written commun., 1986). Logging documented from 1948 to 1970 harvested some trees and cut others for access from about Finnegan's Point to West Creek and harvested some trees in the Dyea area. Parts of the Taiya River valley were homesteaded after the Gold Rush. As of 2019, except for backcountry campgrounds along the Chilkoot Trail, development in the Taiya River valley extends to just north of West Creek. KLGO lands within the mapping area occupy an irregular area about $3 \mathrm{~km}$ long south of West Creek (fig. 3) and contain the Dyea townsite, a campground, ranger facilities, trails, and additional historical sites, including a cemetery. Privately owned parcels include clusters along Dyea Road and along West Creek, an individual parcel bordering the Taiya River at VK 3.5, and a few other isolated parcels elsewhere in the valley bottom. A municipal campground borders KLGO lands near VK 1.2.

Dyea Road crosses the Taiya River $11.4 \mathrm{~km}$ north of Skagway and crosses West Creek another $2.1 \mathrm{~km}$ farther north. The Taiya River bridge, completed in 1948 (Alaska Department of Transportation and Public Facilities, 2010), was protected in 1952 by a dike extending upstream from the bridge along the left bank (as viewed looking downstream) to block a side channel. This dike is presently about $100 \mathrm{~m}$ long and supports the start of the Chilkoot Trail. The bridge across West Creek was first constructed prior to 1979 , abandoned as structurally deficient in 1988, and replaced in 1992 (Alaska Department of Transportation and Public Facilities, 1988, 2012).

\section{Climate and Hydrology}

Temperate maritime conditions prevail in the Taiya River Basin, resulting in cool, wet autumns; cold winters; and moderate summers (table 1). The Coast Mountains create a rain shadow that protects the basin from the more extreme coastal precipitation conditions typical in other southeastern Alaska basins. An average of 1,930 millimeters (mm) of precipitation fell per year during 1971-2000 (Gibson, 2009). Precipitation was distributed primarily as rain in the autumn and snow in the winter, exceeding $250 \mathrm{~mm}$ per month during October-December (Gibson, 2009). The climatic conditions of the West Creek subbasin closely match those of the Taiya River (table 1).

The USGS collected daily mean discharge data for each day (daily discharge) for West Creek for part of water year (WY) 1962 and WY1963-77 and for the Taiya River for WY1970-77 and WY2004-19. The USGS collected annual maximum instantaneous discharge (peak discharge) for West Creek during WY1962-77 and for the Taiya River in WY1967, 1970-76, and 2002-19. This report uses discharge data through WY2017 except where noted. By convention, the water year is the 12-month period from October 1 of the previous calendar year through September 30 of the named water year. During periods of continuous operation, the streamgages recorded subdaily stage, which was translated to subdaily discharge using a rating curve in accordance with Rantz and others (1982) and averaged to obtain the daily discharge. Prior to the present study, the USGS collected 17 suspended sediment measurements in the 1960s at the West Creek streamgage and 13 suspended sediment measurements in the 1970s and WY2004 at the Taiya River streamgage (fig. 4). All USGS discharge and suspended sediment data referenced in this report are available from the USGS National Water Information System (NWIS) (U.S. Geological Survey, 2018).

Mean annual discharge for the available period of record is 34.6 cubic meters per second $\left(\mathrm{m}^{3} / \mathrm{s}\right)$ for the Taiya River and $9.49 \mathrm{~m}^{3} / \mathrm{s}$ for West Creek. Both streams exhibit a summer high-flow-dominated seasonal pattern typical of strongly glacierized basins in Alaska (Curran and others, 2016). 


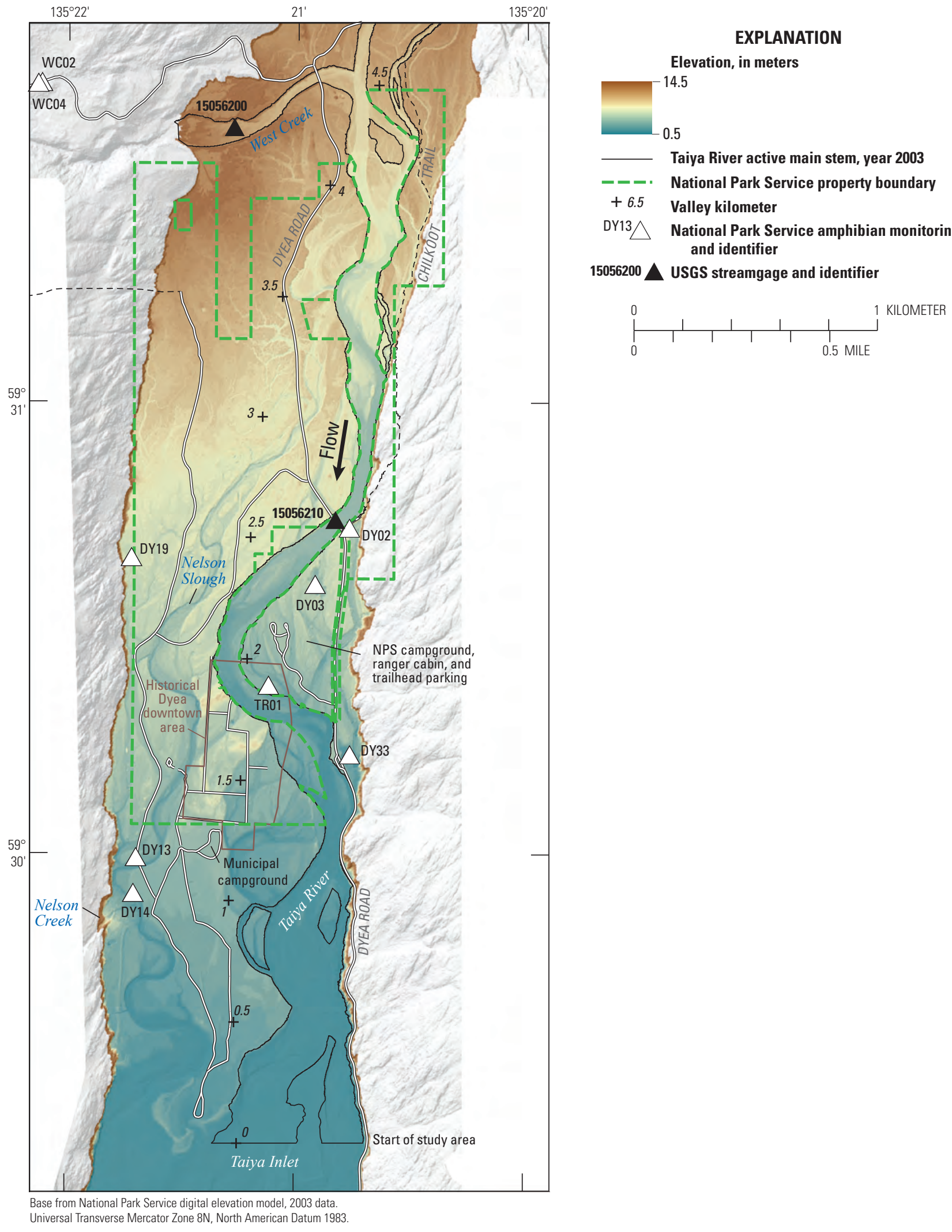

Figure 3. Elevation and locations of features within the most developed part of the main stem Taiya River valley bottom, Alaska. [USGS, U.S. Geological Survey] 


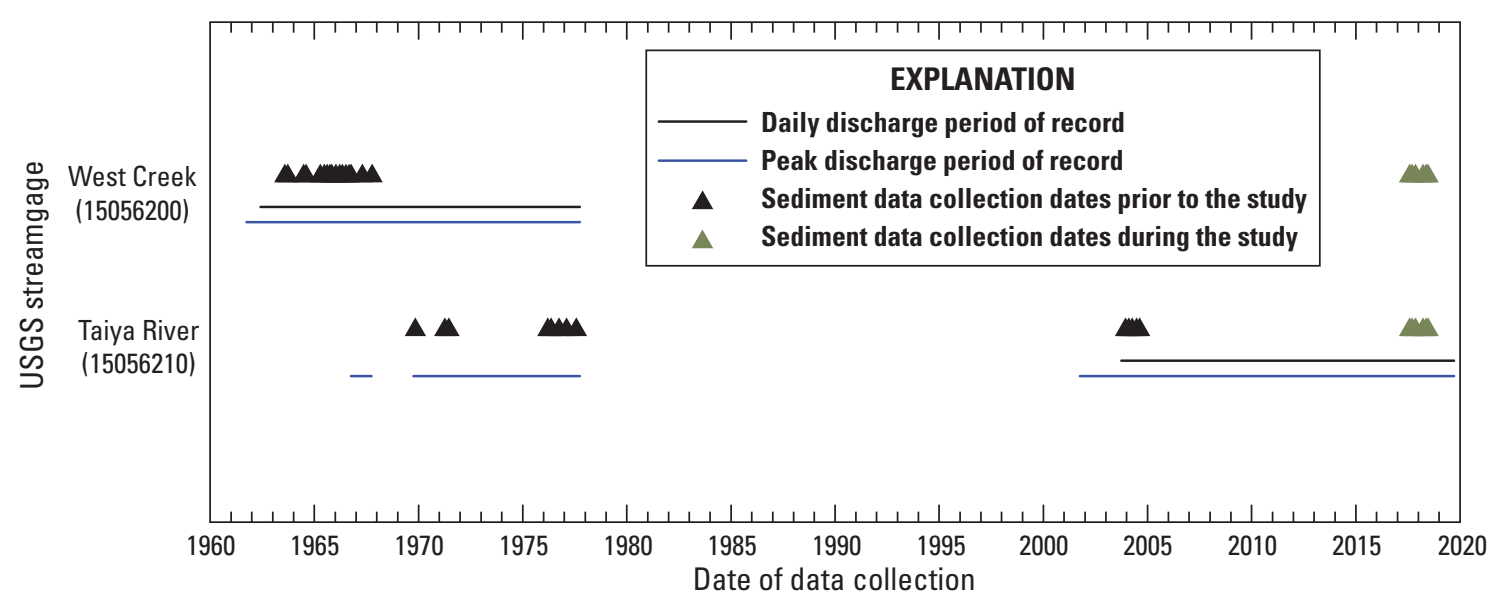

Figure 4. Dates for periods of daily discharge and peak discharge record, and dates of suspended sediment sampling, through water year 2019 at U.S. Geological Survey streamgages at West Creek (15056200) and the Taiya River (15056210), Alaska. [USGS, U.S. Geological Survey]

The hydrograph of the maximum, mean, and minimum daily discharge for the period of record (fig. 5) shows low-flow winters followed by a prominent flow increase from spring snowmelt that leads into a prolonged period of more slowly rising flows associated with high-elevation snowmelt and glacier meltwater runoff (glacier snowmelt and ice melt). Following a crest during late July-early August, mean daily discharge slowly declines except for short-duration increases associated with autumn rainfall events. The high-flow season extends from about May to October, and the low-flow season extends from about November to April. The stream is ice covered for periods in the winter. Individual years of record contain more variability on a daily to weekly basis than long-term means in response to short-term precipitation and temperature fluctuations but follow a general pattern close to the long-term discharge pattern. Bernatz and others (2011) examined the two relatively short periods of Taiya River data available through 2009; the data show statistically significant increases in the proportion of flow arriving in May and June and corresponding decreases for July and August, an earlier spring snowmelt pulse onset, and no changes in streamflow magnitude. Bernatz and others (2011) also found streamflow timing shifts indicating the influence of phase alternations in the Pacific Decadal Oscillation, a pattern of climate variability related to sea surface temperature.

Peak discharge for West Creek and the Taiya River has occurred as early as June and as late as November but is most common in August and September (fig. 5). Likely flood-generating mechanisms for these annual peak discharges include glacier meltwater runoff and rainfall for mid-summer peaks and rainfall for autumn peaks. Over the period of record, peak discharges exceeded the maximum daily discharge for the day of occurrence by an average of 30 percent for both streams, indicating that although the processes that generate peaks are more intense than those associated with typical daily discharge, those processes also tend to elevate discharge for much of the day.

\section{Methods}

To assess the hydrogeomorphic dependence of resources in the mapping area, this study examined the historical context available from existing documents and data, described current conditions through geomorphic mapping, and used aerial photographs, maps, and remote sensing data, field observations, streamflow data, and suspended sediment data to support interpretations of hydrogeomorphic processes. Lines of investigation included a review of the hydrologic history of West Creek and the Taiya River, including glacial lake outburst floods, from historical records; reconnaissance of concurrent discrete suspended sediment in the two streams using new data; documentation of channel migration history and geomorphic features from lidar and aerial photos; examination of streamgage data for evidence of incision; and observations of current conditions of selected park resources.

\section{Streamflow Data and Flood History Compilation}

Streamflow data provided information on seasonality, magnitude, and changes to daily discharge and peak discharge since the 1960s. Datasets obtained included daily discharge, daily and annual statistics for daily discharge, and peak discharge at the West Creek and Taiya River streamgages. Statistical comparisons of discharge between different periods used Student's t-test at the 95-percent confidence level and were considered significant for $\mathrm{p}<0.05$. Pearson's $r$ coefficients were used to assess the similarity of daily discharge patterns between streams.

A geomorphically comprehensive view of flooding in the Taiya River Basin required consideration of historical accounts and geomorphic evidence in addition to streamgage data because the streamgage record is short and the deglaciation process can dynamically affect the storage and release 
of water. In addition to USGS streamgage records (U.S. Geological Survey, 2018) and reports (Boning, 1972), flood information sources include historical accounts of large floods in Gold Rush era newspapers (Sacramento Daily Union, 1897; The Seattle Post-Intelligencer, 1897), compilations or discussions of pre-gaging flood information (Inglis and Pranger, 2002; Buzzell, 2004; Municipality of Skagway, 2009; Gurcke, 2010), investigations of glacial lake outburst floods or flood potential in the Taiya River Basin (Post and Mayo, 1971; Streveler, 1995; Capps, 2004; Denton and others, 2009), and visual interpretations of historical aerial photographs (McArthur, 1894).

\section{Discrete Suspended Sediment Data Collection}

Suspended sediment conditions are of interest for understanding the distribution and seasonal use of the Taiya River by aquatic organisms and for engineering considerations and environmental effects from potential use of West Creek. No concurrent measurements on West Creek and Taiya River were available for comparison of suspended sediment conditions prior to this study, and previous measurements (fig. 4) could not be assumed to represent current conditions. For this study, six discrete suspended sediment samples were collected from each stream near the USGS streamgages using standard USGS methods (Edwards and Glysson, 1999) at a range of discharges throughout the study period of October 2017-June 2018. Discharge measurements collected at the same time as sampling provided data for computation of suspended sediment load. Sampling was conducted nearly concurrently (within several hours) for the two streams, except for the July/ August 2017 sampling, which occurred on consecutive days during a period of relatively stable discharge (daily discharge varied by less than 5 percent between sampling days). Discharge conditions at the time of sampling guided selection of either the equal discharge increment or equal width increment sampling methodology, both of which resulted in depthintegrated samples. Samples were collected at 5-10 locations across the stream and composited to ensure a sample representative of the stream cross section. All sediment samples were analyzed at the USGS Cascades Volcano Observatory sediment laboratory to determine the sediment concentration and percentage of sediment finer than $0.0625 \mathrm{~mm}$ (silt and clay). The instantaneous discharge measurement and discrete suspended sediment data were published online via the NWIS as Water Quality "Field/Lab Samples" (U.S. Geological Survey, 2018). Instantaneous suspended sediment loads, also known as suspended sediment discharge, computed as the product of instantaneous discharge and discrete suspended sediment concentration and the appropriate unit conversion factors, were also published in NWIS.
A. West Creek, USGS streamgage 15056200

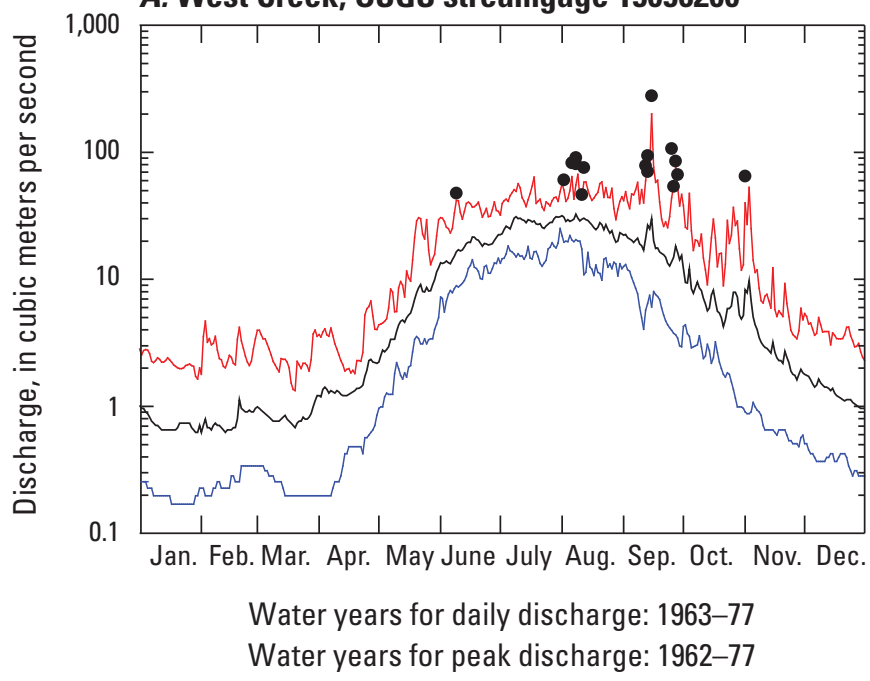

B. Taiya River, USGS streamgage 15056210

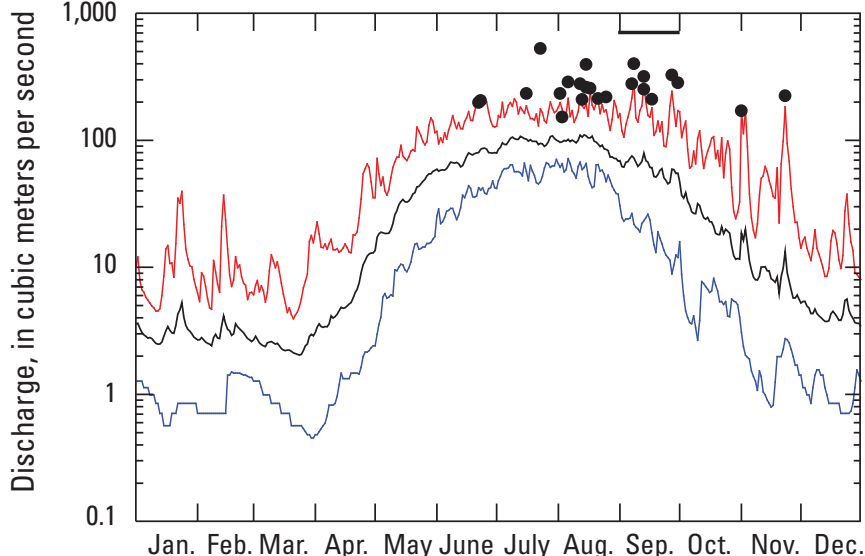

Water years for daily discharge: 1970-77, 2004-17 Water years for peak discharge: 1967, 1970-76, 2002-17

\section{EXPLANATION}

- Maximum daily discharge
- Mean daily discharge
- Minimum daily discharge
- Peak discharge, day of occurrence unknown
Peak discharge

Figure 5. Maximum, mean, and minimum daily discharge and peak discharge during the period of record for U.S. Geological Survey streamgages on $A$, West Creek (15056200) and $B$, Taiya River (15056210), Alaska. Values are plotted by calendar year rather than water year to avoid breaks in seasonal patterns. Peak discharge is plotted as a bar for the month when the day is unknown. [USGS, U.S. Geological Survey] 
Bedload transport affects channel scour and deposition and can be an important factor in channel migration and aquatic habitat complexity. This study considered bedload characteristics and conditions through geomorphic evidence discussed in the "Geomorphic Mapping and Analysis" section because bedload sampling was not within the scope of this study.

\section{Geomorphic Mapping and Analysis}

Geomorphic mapping provided a means to identify existing fluvial features and document evidence for historical channel location and geomorphology, and analysis of historical streamgage water-surface-elevation data provided an estimate of vertical change, which together formed a basis for evaluating the hydrogeomorphic dependence of KLGO resources. Geomorphic maps document the distribution of geomorphic features and provide a basis for interpretation of the processes that shaped the ground surface. The Taiya River main stem valley is likely underlain nearly ubiquitously by fluvial deposits, making fluvial process and timing more effective than geology for differentiating various parts of the valley bottom. For this study, the primary goals of geomorphic mapping were to provide a preliminary delineation of the West Creek alluvial fan, document Taiya River channel migration in the mapping area since the advent of high-resolution aerial photography (1948-2018), detect and document the location of channels other than active main stem channels that could provide wetland or stream habitat, and provide information regarding recent channel activity from which to infer bedload transport conditions. In a broader context, the goals of this mapping included gaining an understanding of the hydrologically important features of the mapping area, the hydrologic connectivity between main stem and off-main-stem environments, and the sources of water in abandoned and active side channels. Mapping products consist of (1) a geomorphic surfaces map depicting existing surfaces by formative process (main stem, tributary, or tidal), subdivided by age category for fluvial surfaces, and (2) a map of off-main-stem channels within those surfaces. The geomorphic surfaces and off-main-stem channels were mapped for 2003 conditions to match available elevation data and adjusted to show small areas eroded by the main stem by 2018 to better represent present conditions.

Multiple sources and types of data (table 2) provided insight at different temporal and spatial scales to support geomorphic mapping. A 2003 lidar elevation dataset, reprocessed to a preferred coordinate system and adjusted by the vendor to improve vertical accuracy for this project in 2017 , provided the basis for map delineations. Interpretations of surface features were based on the 2003 lidar, a corresponding 2003 orthophotograph, other aerial photographs or orthophotographs from 1948 to 2018 at near-decadal intervals for part or all of the mapping area and georeferenced by NPS, historical ground photos from 1894, interferometric synthetic aperture radar (IfSAR) elevation data for Alaska, USGS 7.5-minute topographic maps, historical maps, and field reconnaissance observations during foot surveys and one raft float from August 28 to September 1, 2017, and June 16 to 20, 2018. Map feature delineations were digitized in a geographic information system (GIS) at a scale of about 1:2000 or by tracing slope derivatives prepared from the lidar data.

The 2003 lidar data were viewed in several ways to aid feature interpretation and delineation. First, a digital elevation model was shaded in $0.5-\mathrm{m}$ elevation bands and draped over a hillshade model (fig. 6A) to enhance visibility of geomorphic features while retaining actual elevation data. Second, a relative elevation model (REM) map, sometimes referred to as height above river map (Jones, 2006) or height above water surface map (Carpenter and others, 2012), was created to better visualize patterns in geomorphic features to aid interpretation. The REM map is an elevation model of the main stem detrended for the local slope of the Taiya River (and Nourse River near the head of the valley). Following procedures in Olson and others (2014, appendix E), water-surface elevations along the stream centerline were extracted from the 2003 lidar digital elevation model (DEM) and used with an inverse distance weighting tool in ArcGIS to create a model of the weighted average elevations of the nearest Taiya River water surfaces for any point across the valley. The original DEM was subtracted from this modeled water-surface elevation, which slopes at approximately the valley slope, to create the REM. The REM map facilitated qualitative analysis of former river positions and cross-cutting relations, such as fan trimlines. Finally, a slope map was prepared as a derivative of the lidar elevation data and then contoured to a range of values using ArcGIS tools to guide mapping. The most prominent steep slopes in the Taiya River valley are present at streambanks and human-modified features like roadway embankments and dikes, making slope a definitive and accurate tool for visualizing and delineating channels, a process used successfully on other streams (Jones, 2006). By visual trial and error, slope contour values were sought that minimized noise but provided enough detail to distinguish geomorphic features. The 15-percent slope contour, one of several suitable contour values, was selected in part because it is a commonly used steep-slope boundary. 
Table 2. Data sources used for mapping and interpretation of geomorphic features in the Taiya River Basin, Alaska.

[Source and publication data: Accessed from internal National Park Service Klondike Gold Rush Historical Park archives except as noted. National Park Service data are accessible at on the Integrated Resource Management Applications (IRMA) Data Store at https://irma.nps.gov/DataStore/ using the Reference Code shown. Abbreviations: cm, centimeter; m, meter; NPS, National Park Service; USGS, U.S. Geological Survey; --, not available; n/a, not applicable; no., number]

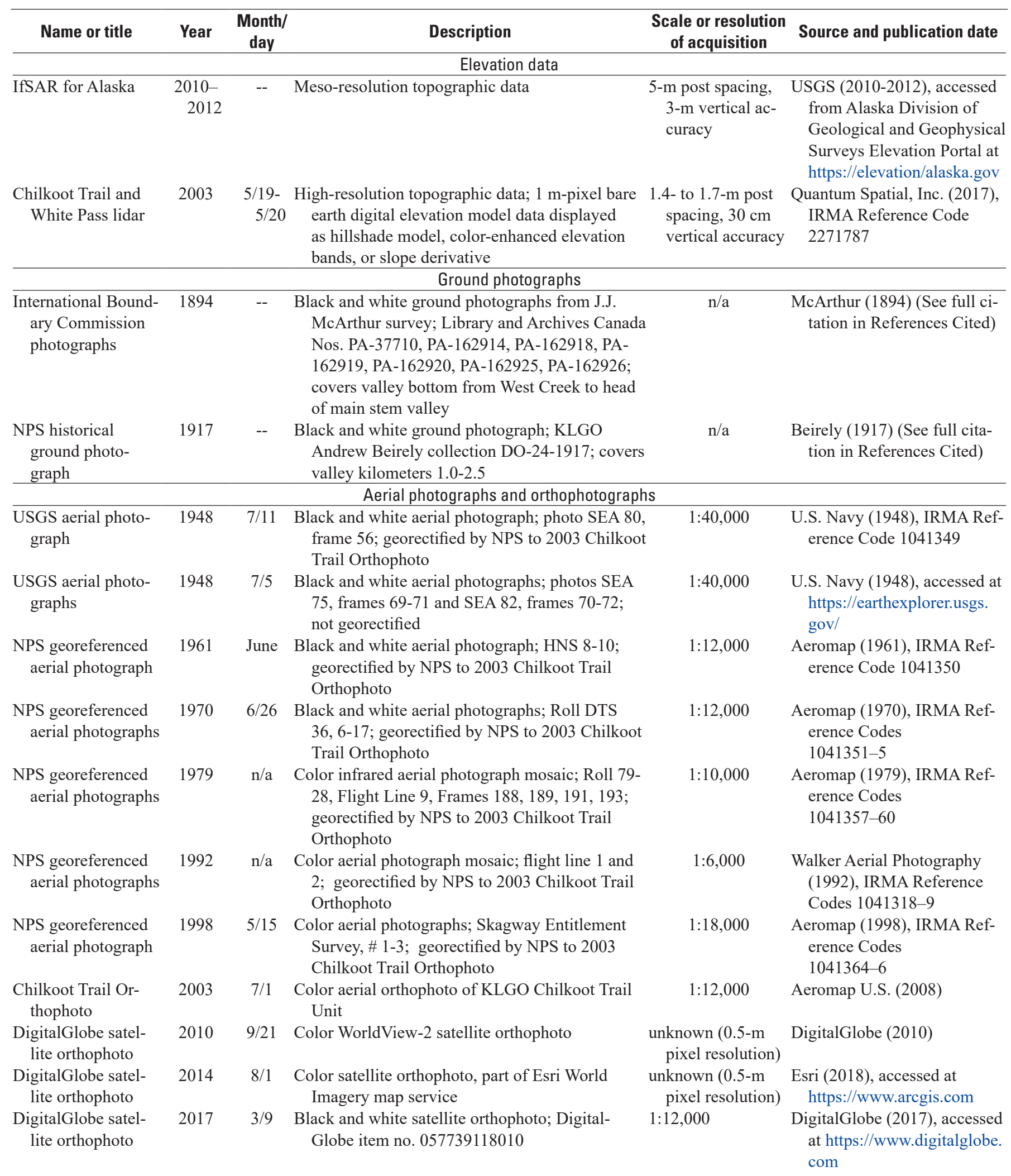


Table 2. Data sources used for mapping and interpretation of geomorphic features in the Taiya River Basin, Alaska.-Continued

\begin{tabular}{|c|c|c|c|c|c|}
\hline Name or title & Year & $\begin{array}{c}\text { Month/ } \\
\text { day }\end{array}$ & Description & $\begin{array}{l}\text { Scale or resolution } \\
\text { of acquisition }\end{array}$ & Source and publication date \\
\hline \multicolumn{6}{|c|}{ Maps } \\
\hline $\begin{array}{l}\text { Alaska Boundary } \\
\text { Tribunal topo- } \\
\text { graphic map }\end{array}$ & $\begin{array}{l}1904 \\
(1894 \\
\text { ground } \\
\text { date })\end{array}$ & $\mathrm{n} / \mathrm{a}$ & $\begin{array}{l}\text { Earliest formal survey of the region; Sheet No. 17; } \\
\text { ground date estimated to be } 1894 \text { from features } \\
\text { depicted and correspondence of location of } \\
\text { triangulation stations to locations of } 1894 \text { Inter- } \\
\text { national Boundary Commission photographs }\end{array}$ & $1: 160,000$ & $\begin{array}{l}\text { Alaska Boundary Tribunal } \\
\text { (1904), accessed online } \\
\text { (See full citation in Refer- } \\
\text { ences Cited) }\end{array}$ \\
\hline $\begin{array}{l}\text { USGS topographic } \\
\text { map }\end{array}$ & 1951 & $\mathrm{n} / \mathrm{a}$ & Topographic map & $1: 63,000$ & USGS (1951) \\
\hline
\end{tabular}

Most channels and the valley bottom margins were drawn by tracing 15-percent slope contours and digitizing as needed to connect contours. Tracing results in a repeatable, consistently defined line, but it should be noted that the level of detail conveyed by tracing is often more than warranted given the resolution of the data. Although the steep slope map (areas steeper than or equal to 15 percent; fig. $6 B$ ) clearly depicts steep-sided feature outlines, additional information gleaned from aerial photographs (fig. $6 C$ ) and field observations was required for the interpretation of the formative process and relative age of the features (fig. 6D).

Interpretations of geomorphic surface formative process and relative age, and off-main-stem channel attributes, relied on surface texture, abrupt elevation differences, cross-valley slopes, vegetation age and patterns, and presence of water. Using present main stem patterns as a guide, geomorphic surfaces were assumed to be abandoned main stem Taiya River channels when channel scars with a relatively long radius of curvature could be detected. These former channels appeared in elevation data as curvilinear troughs, in aerial photographs as curvilinear changes in vegetation height or composition, and on the slope map as bounded by curvilinear steep areas. Groundwater presence was inferred where dark areas representing open water in off-main-stem channels appeared in a snow-covered winter image from 2017 (table 2) because groundwater generally emerges at a relatively constant temperature that is often warmer than air temperatures in winter. Interpretation of vegetation patterns considered the area's history of alterations by logging and homesteading activities and avoided overemphasizing tree-stand age or composition.

The mapping area surfaces were mapped into six geomorphic units (table 3 ) consisting of fluvial or uplifted estuarine surfaces. Main stem surfaces were divided into active and abandoned main-stem surfaces and subdivided by relative age (active in 2003 versus created by erosion after 2003 or abandoned prior to the 1940 s versus after the 1940 s, respectively). The active main stem is defined here as the suite of major channels, bars, islands, and associated minor channels that form a nearly continuous unvegetated area, plus major sloughs unlikely to contain shallow, low-velocity flow. Sloughs are defined here as small channels conveying main-stem water across a surface then reentering the main stem downstream. Historically active main-stem surfaces were arbitrarily divided into recently abandoned and older abandoned surfaces by their appearance in the 1948 aerial photograph; essentially bare or lightly vegetated surfaces visible in the photograph were estimated to be less than a decade old, establishing the decade of the 1940s as the boundary. Any small channels that appeared to have developed on an abandoned surface were considered part of the surrounding larger surface for the purposes of geomorphic surface mapping. Alluvial fans were mapped as a single category that included high-angle fans from small tributaries and the low-angle fan from West Creek. Former tidal flats uplifted by isostatic rebound and not fluvially reworked constituted the only nonfluvial surface category. Because the geomorphic mapping focused on the fluvial history of the valley, a few small nonfluvial features or human-modified features were ignored. Changes in the 15 years since the 2003 base-map data were partly accommodated by mapping eroded areas as an active main stem category (table 3 ), but abandonment of areas active in 2003 was difficult to determine conclusively. Areas abandoned since 2003 were likely not extensive, but their absence on the map does not reflect any assessment of the balance between areas eroded and areas abandoned. 

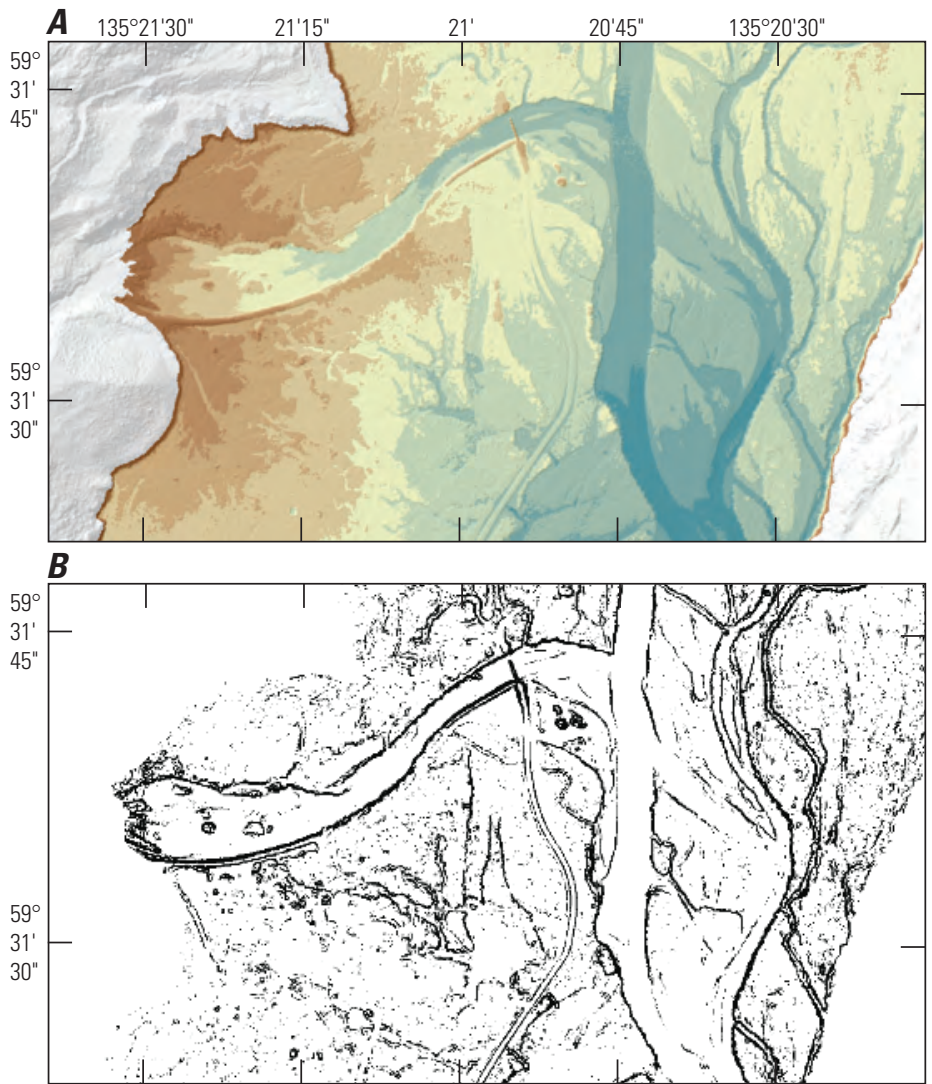

C
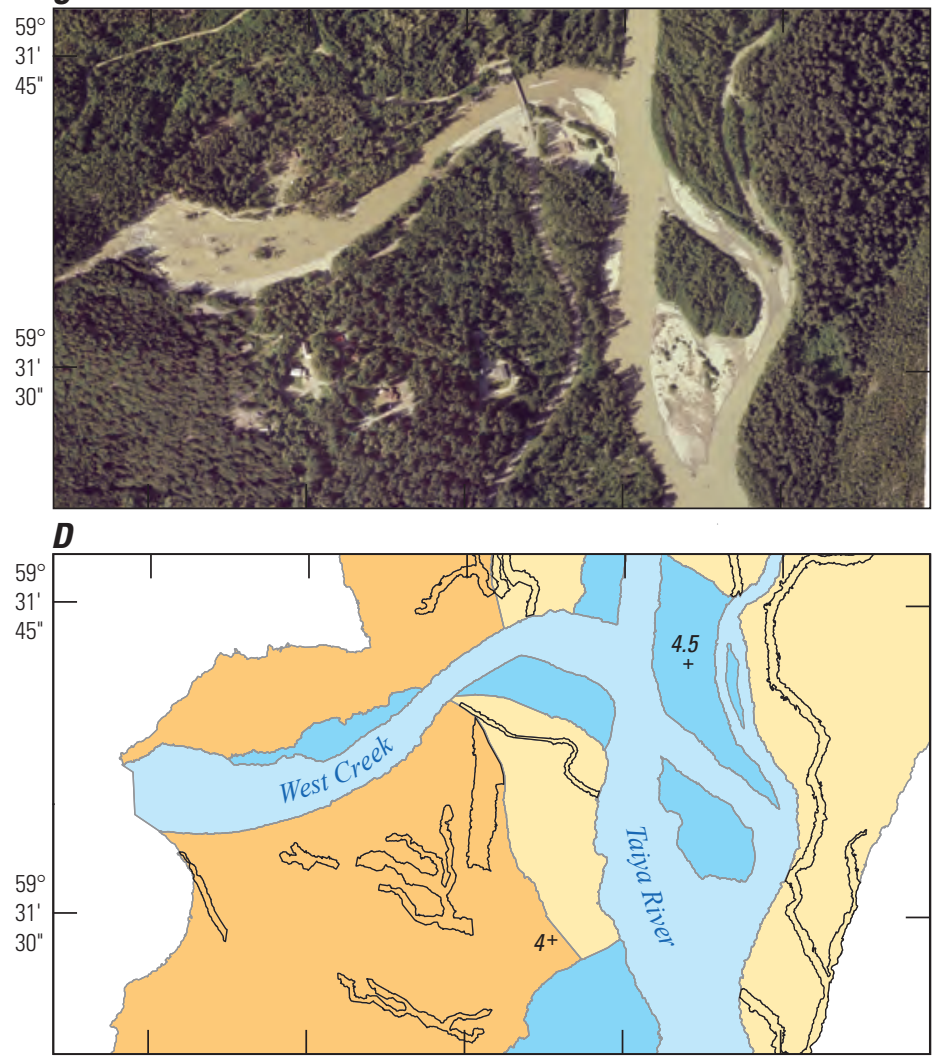

\section{EXPLANATION}

Elevation, in meters

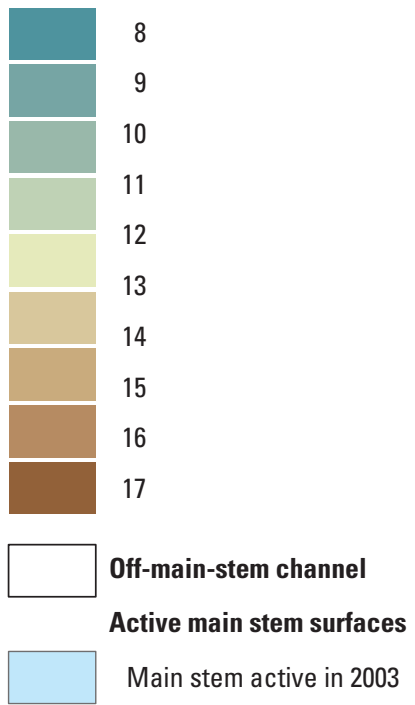

Abandoned main stem surfaces

Main stem abandoned between 1940s and 2003

Main stem abandoned prior to 1940 s

\section{Other surfaces}

Alluvial fan

E 6.5 Valley kilometer

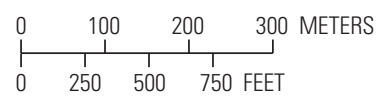

Figure 6. Examples of geospatial products used for geomorphic mapping and an example completed geomorphic map for a section of the mapping area in the Taiya River valley, Alaska. A, The 2003 Light Detection and Ranging (lidar) data colored at 1-meter intervals to enhance feature boundaries in the valley bottom and shaded as a hillshade model for valley walls to identify geomorphic features. B, A steep slope map created from 2003 lidar to identify channel banks. Black areas show slopes greater than or equal to 15 percent. Contours of 15-percent slope (not shown) were traced to generate boundaries shown in $D$. C, 2003 aerial orthophotography showing the distribution of water and the relative age of vegetation. $D$, The completed geomorphic map including several categories of geomorphic surfaces and offmain-stem channels. 
Table 3. Descriptions of geomorphic surfaces mapped for the lower 7.5 kilometers of the Taiya River valley bottom, Alaska.

[Abbreviations: --, no data; km, kilometer]

\begin{tabular}{|c|c|c|c|}
\hline Geomorphic surface unit & Period when active & Description & Defining characteristics \\
\hline \multicolumn{4}{|c|}{ Active main-stem surfaces } \\
\hline $\begin{array}{l}\text { Main stem activated } \\
\text { between 2003-2018 }\end{array}$ & post-2003 to present & $\begin{array}{l}\text { Wetted channels and unvegetated bars of the } \\
\text { Taiya River and West Creek incorporated } \\
\text { into the main stem since } 2003\end{array}$ & $\begin{array}{l}\text { Wetted channel in } 2017 \text { (entire study area) } \\
\text { or } 2018 \text { (southern } 2 \mathrm{~km} \text { of study area) } \\
\text { but not in } 2003\end{array}$ \\
\hline Main stem active in 2003 & 2003-present & $\begin{array}{l}\text { Wetted channel and unvegetated to lightly } \\
\text { vegetated bars of the Taiya River and West } \\
\text { Creek }\end{array}$ & $\begin{array}{l}\text { Wetted channel and unvegetated to lightly } \\
\text { vegetated bars in } 2003\end{array}$ \\
\hline $\begin{array}{l}\text { Main stem abandoned be- } \\
\text { tween } 1940 \text { s-2003 }\end{array}$ & 1940s-2003 & $\begin{array}{l}\text { Former channels and bars of the Taiya River } \\
\text { and West Creek that were abandoned be- } \\
\text { tween 1940s-2003 }\end{array}$ & $\begin{array}{l}\text { Wetted channel and unvegetated to lightly } \\
\text { vegetated bars in 1948, vegetated areas } \\
\text { in } 2003\end{array}$ \\
\hline $\begin{array}{l}\text { Main stem abandoned prior } \\
\text { to } 1940 \mathrm{~s}\end{array}$ & pre-1940s & $\begin{array}{l}\text { Former channels and bars of the Taiya River } \\
\text { and West Creek that were abandoned prior } \\
\text { to the } 1940 \mathrm{~s}\end{array}$ & $\begin{array}{l}\text { No wetted channel or bars in } 1948 \text { or later, } \\
\text { channel forms evident in topographic } \\
\text { expression }\end{array}$ \\
\hline Emergent tidal flat & -- & $\begin{array}{l}\text { Uplifted former tidal surfaces not fluvially } \\
\text { reworked }\end{array}$ & $\begin{array}{l}\text { Relatively smooth surfaces at or near mean } \\
\text { higher-higher water elevation }\end{array}$ \\
\hline
\end{tabular}

An inventory of all major existing channel forms within the mapping area, other than the suite of active main stem channels, bars, and sloughs, was conducted for a second map. Channels were identified as features having two well-defined banks, a bed elevation lower than the surrounding surface, and a length more than about $100 \mathrm{~m}$. The channels were assigned attributes from field and imagery observations that indicated connectivity to water sources and sinks (surface-water body receiving outflow) and the presence of surface water (table 4). Water sources that could be definitively attributed to the channels consisted of surface water, further categorized as main stem (readily detectable as turbid from glacial sources) or tributary. Where no obvious surface-water connection could be detected but water was present, potential water sources could include local snowmelt or local precipitation, but the primary water source for many of the wetlands, ponds, and intermittent streams in the nonconnected channels was inferred to be groundwater discharge. Evidence of groundwater contributions included open leads from likely warmer water in winter orthophotos, but confirmation of the presence of groundwater would require additional investigation beyond the scope of this study. The channels were categorized by origin as an abandoned main stem channel, a tributary-affected channel, or unknown.

To provide a cursory examination of evidence for vertical streambed elevation change (incision or deposition), historical stage data for the USGS Taiya River streamgage were analyzed. The balance between vertical uplift, incision, and the downstream horizontal migration of river base-level location can be partly quantified by examining streambed change inferred from long-term stage-discharge changes (James, 1991; Smelser and Schmidt, 1998; Juracek and Fitzpatrick, 2009; Slater and others, 2015; Anderson and Konrad, 2019) at the Taiya River streamgage. A streamgage rating curve relates the measured stream stage, or water-surface elevation, to discharge for a range of discharges and is updated over time to accommodate changes in streambed elevation, geometry, or roughness elements. For the Taiya River at the Dyea Road bridge, where the channel occupies most of the bridge opening, changes in stage for most discharges over time can be assumed to equate to changes in streambed elevation. To quantify these changes, stage comparison techniques modified from Anderson and Konrad (2019) were applied to historical discharge measurement records for the Taiya River. For each historical discharge through 2019, the difference between the historical stage and the stage estimated from the most recent rating curve (2016) for the same discharge was computed. When plotted as a time series, these individual historical-recent stage differences show long-term and short-term patterns of bed elevation change. For the Taiya River, flows were constrained to $7.5-98.1 \mathrm{~m}^{3} / \mathrm{s}$, the maximum ice-affected discharge in the data and the mean monthly July discharge, respectively. These discharge-based but somewhat arbitrary bounds reduced variability in stage potentially attributable to the effect of ice at low discharges and vegetation or other cross section changes at very high discharges. 
Table 4. Definitions of attributes for off-main-stem channels mapped for the lower 7.5 kilometers of the Taiya River valley bottom, Alaska.

\begin{tabular}{|c|c|}
\hline Category short name and options & Definition \\
\hline Head & Surface-water connection conditions at the upstream end of mapped off-main-stem channels \\
\hline Inaccessible & $\begin{array}{l}\text { Blocked by sediment, elevated above estimated typical flood levels, or located away from surface-water } \\
\text { sources }\end{array}$ \\
\hline Evidence of flow & not blocked by sediment, flood debris visible or vegetation absent \\
\hline Not blocked & not blocked by sediment, no flood debris visible or vegetation is present \\
\hline Inaccessible & $\begin{array}{l}\text { blocked by sediment, elevated above estimated typical flood levels, or located away from surface-water } \\
\text { sources }\end{array}$ \\
\hline Flowing & not blocked by sediment, water flow exits channel at least part of the year \\
\hline Not blocked & not blocked by sediment, no flood debris visible or vegetation is present \\
\hline Unknown & not observed during field observations and not visible on aerial imagery \\
\hline wtr_source & Water sources observed or inferred for mapped off-main-stem channels \\
\hline Off-main-stem channel & flow from another off-main-stem channel \\
\hline Tributary & flow from a tributary to West Creek or the Taiya River \\
\hline None & no water source observed or inferred \\
\hline Unknown & water sources or lack of water sources could not be determined \\
\hline SW_sink & Surface-water body receiving off-main-stem channel flow \\
\hline Main stem & drains to a main-stem channel or slough \\
\hline Off-main-stem channel & drains to another off-main-stem channel \\
\hline Ocean & drains to Taiya Inlet \\
\hline None & exit is inaccessible \\
\hline obs_date & Date and source of observations of mapped off-main-stem channel \\
\hline Date, methods & calendar date and data source (field observations, aerial photograph, or orthophotograph) \\
\hline Limited flow & flow was detectable in some locations, water surface elevation was relatively flat \\
\hline Ponded & no flow was visually detectable \\
\hline None & no water was present \\
\hline Unknown & not observed during field observations and not visible on aerial imagery \\
\hline Abandoned & Date of abandonment of mapped off-main-stem channel by main stem Taiya River or West Creek \\
\hline Prior to 1948 & not occupied in the 1948 aerial photograph \\
\hline After 1948 & occupied in the 1948 aerial photograph \\
\hline $\mathrm{n} / \mathrm{a}$ & associated with a tributary, not the main stem \\
\hline Unknown & conditions ambiguous in the 1948 aerial photograph \\
\hline form_proc & Formative processes associated with mapped off-main stem channel \\
\hline Main stem & formed by active main stem processes by West Creek or the Taiya River \\
\hline Tributary & formed or modified by tributary to West Creek or the Taiya River \\
\hline Unknown & form and location suggest formation by process other than main stem or tributary \\
\hline Culvert & Infrastructure observed at road or trail crossing of mapped off-main-stem channel \\
\hline Culvert & a culvert was present at the road or trail crossing \\
\hline No culvert & no culvert was present at the road or trail crossing \\
\hline Footbridge & a footbridge was present at the trail crossing \\
\hline No road & no road crossed the stream \\
\hline Unknown & the road or trail crossing was not observed during field investigations \\
\hline
\end{tabular}




\section{Hydrogeomorphically Dependent Park Resources}

From discussions with NPS staff and review of available literature and summary documents (Hood and others, 2006; Bernatz and others, 2011), several KLGO resources were considered critically dependent on hydrologic or geomorphic conditions in the mapping area. These resources included biological resources such as anadromous and resident fish and amphibians, cultural resources (including historical sites) and archeological resources near potentially eroding banks, and recreation. Of these, this project focused on river recreation, boreal toad habitat, and sites near eroding banks as the most site specific, most dependent on specific flow regimes, and the hardest to assess from published literature. This study sought to identify hydrologic and (or) geomorphic conditions relevant to these resources to help NPS evaluate the sensitivity of the resources to present or future river conditions.

Hydrogeomorphic dependent conditions for rafting, the most common hydrologically dependent recreational use of the Taiya River, were assessed by a single raft float from the commonly used, road-accessed launch (VK 4.7) and landing (VK 1.6) on August 30, 2017. This float provided access to gravel bars and side channels, observations of bank conditions, and observations of potential recreational river navigation hazards at relatively high-flow conditions $\left(121 \mathrm{~m}^{3} / \mathrm{s}\right)$. Informal discussions with local rafting tour company guides at the landing on this date and during a site visit on June 18, 2018, provided information regarding common river hazards and limitations on float-tour operation related to hydrogeomorphic conditions.

KLGO identified the locations of several boreal toad breeding sites (fig. 3) during KLGO amphibian monitoring surveys initiated in 2004 (Surdyk and Waldo, 2018). These locations, all within wetlands, were overlain on the geomorphic map to inventory the geomorphic features containing the sites. Information from mapping data sources and from field observations of hydrologic conditions was used to infer potential water sources for these wetlands.

Existing and proposed NPS infrastructure and cultural and historical resources situated near the banks of the Taiya River are sensitive to channel migration that results in bank erosion. Bank erosion was assessed from the geomorphic mapping for this project by onscreen measurements of eroded areas mapped as "main stem activated between 2003-2018," by inspection of channel migration implied by areas mapped as "main stem abandoned between 1940s-2003" and "main stem active in 2003," and by inspection of 1948 and 2003 aerial photographs. Additional bank erosion information was provided by ground surveys conducted as part of ongoing bank erosion monitoring efforts at selected banks by KLGO staff (Richards and others, 2017).

\section{Surface-Water Hydrology and Suspended Sediment}

Glacier-related processes in the West Creek and Nourse River basins have been a primary driver of patterns of seasonal streamflow, large floods, and sediment delivery in the main stem Taiya River since at least the Gold Rush. In addition to generating turbid, prolonged summer high flows typical of glacierized basins, glaciers in the study area have been associated with the filling and draining of various lakes, which can regulate sediment storage and release in addition to facilitating outburst floods. Additional hydrologic affects include rainfallrelated flooding and decadal-scale shifts in timing of seasonal patterns associated with climate patterns.

\section{Streamflow Since the 1960s}

\section{Decadal-Scale Change}

The intermittent and relatively short streamgage records precluded in-depth trend analysis but permitted comparisons of early to late periods. Using data through WY2009, Bernatz and others (2011) found no statistically significant difference in mean annual discharge of the Taiya River between the respective periods of record in the 1970s and 2000s in a Student's t test. Results of an updated analysis using records through WY2017 (fig. 7) (table 5) show that an increase in mean annual discharge in the latter period weakly fails to be statistically significant $(\mathrm{p}=0.073)$. The same analysis for West Creek shows no statistically significant difference in the mean annual discharge between the common period of record with the Taiya River in the 1970s and the earlier years of West Creek record (fig. 7).

More closely examining the seasonal distribution of flow for the Taiya River between periods, however, shows discernible changes in flow timing and magnitude for parts of the year (table 5, fig. 8). An overlay of the mean daily discharge for the two periods (fig. 8) shows a shift in timing of an average of 14 days toward earlier spring breakup in the more recent period, which echoes findings of a statistically significant earlier spring pulse onset (sudden increase in discharge associated with spring snowmelt) in Bernatz and others (2011). A corresponding statistically significant increase in mean monthly discharge for April-June during the WY2004-17 period compared to the 1970 s period (table 5) is also consistent with the Bernatz and others (2011) seasonal fractional flow analysis showing a higher percentage of the annual discharge being delivered in May and June. Spring and early summer flow increases in the more recent period are not fully compensated by decreases in other parts of the year (table 5). The decrease in flow delivered in July and August reported by Bernatz and others (2011) is minor and not statistically significant in the present analysis. Winter (December-March) mean monthly discharges are slightly higher but not statistically significant or weakly not significant in the more recent period. 


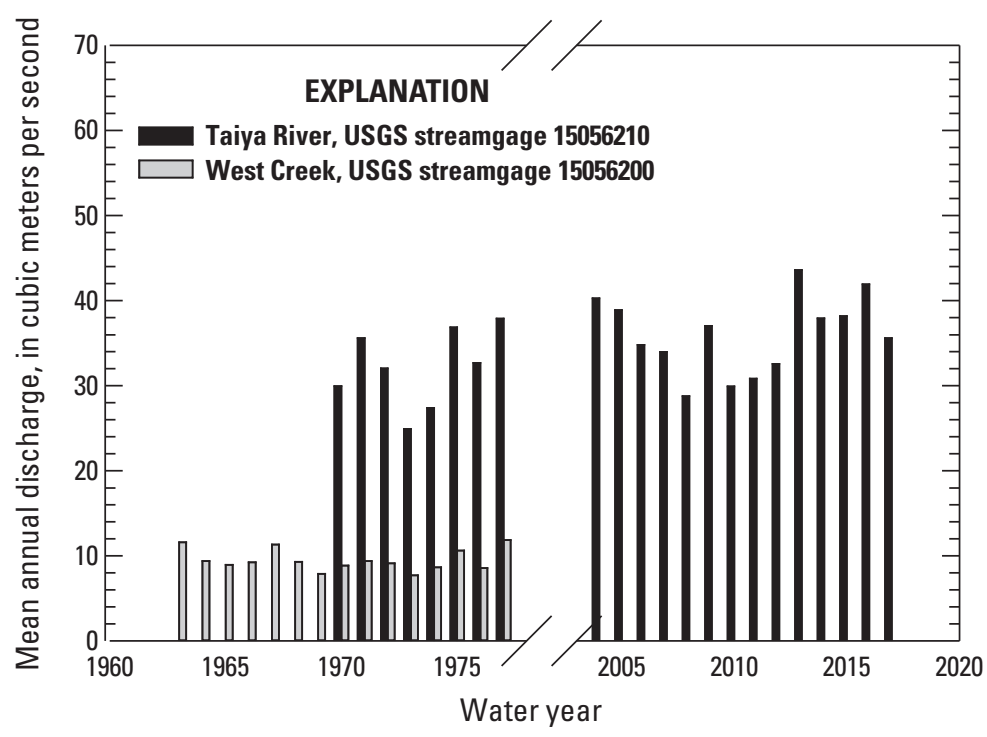

Figure 7. Mean annual discharge for each year through water year 2017 at U.S. Geological Survey streamgages at West Creek (15056200) and Taiya River (15056210), Alaska. [USGS, U.S. Geological Survey]

Table 5. Differences in mean monthly and mean annual discharge between water years 1970-77 and water years 2004-17 for the Taiya River, Alaska, at U.S. Geological Survey streamgage 15056210.

[Values are bolded where significant at the 95 -percent confidence level. Abbreviations: WY, water year; $\mathrm{m}^{3} / \mathrm{s}$, cubic meters per second]

\begin{tabular}{|c|c|c|c|c|}
\hline Period & $\begin{array}{l}\text { Mean discharge, } \\
\text { WY1970-77 }\left(\mathrm{m}^{3} / \mathrm{s}\right)\end{array}$ & $\begin{array}{l}\text { Mean discharge, } \\
\text { WY2004-17 (m³/s) }\end{array}$ & $\begin{array}{l}\text { Difference between mean } \\
\text { discharges for WY2004-17 and } \\
\text { WY1970-77 (percent increase) }\end{array}$ & $\begin{array}{l}\text { p-value of } \\
\text { t-test of } \\
\text { means }\end{array}$ \\
\hline January & 2.35 & 3.70 & 57 & 0.068 \\
\hline February & 2.71 & 3.12 & 15 & 0.505 \\
\hline March & 2.07 & 2.63 & 27 & 0.294 \\
\hline April & 3.63 & 7.68 & 112 & 0.006 \\
\hline May & 19.6 & 42.1 & 115 & 0.000 \\
\hline June & 57.8 & 79.8 & 38 & 0.002 \\
\hline July & 100 & 97.0 & -3 & 0.738 \\
\hline August & 98.6 & 91.7 & -7 & 0.409 \\
\hline September & 58.2 & 63.3 & 9 & 0.532 \\
\hline October & 22.9 & 25.5 & 11 & 0.578 \\
\hline November & 11.5 & 8.97 & -22 & 0.473 \\
\hline December & 4.11 & 4.46 & 9 & 0.775 \\
\hline Annual & 32.2 & 36.0 & 12 & 0.073 \\
\hline
\end{tabular}




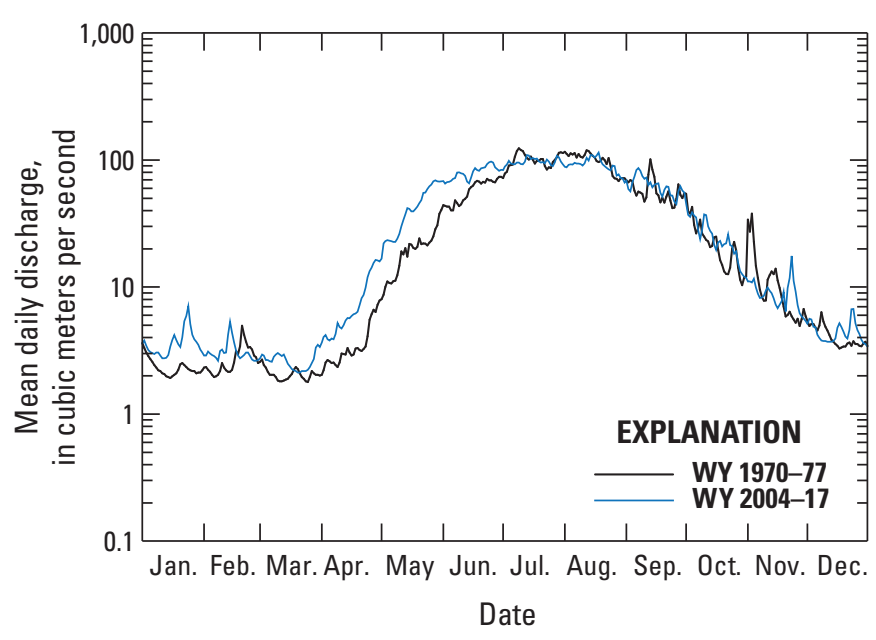

Figure 8. Mean daily discharge for the Taiya River at U.S. Geological Survey streamgage 15056210, Alaska, water years 1970-77 and water years 2004-17. [WY, water year]

\section{Comparisons Between West Creek and Taiya River Discharge}

Averaged over the common period of record, West Creek mean annual discharge $\left(9.32 \mathrm{~m}^{3} / \mathrm{s}\right)$ averaged 29 percent of Taiya River mean annual discharge $\left(32.2 \mathrm{~m}^{3} / \mathrm{s}\right)$ at the respective streamgages. At the streamgage location, the Taiya River includes the combined discharge from both streams adjusted by any contributions from or losses to groundwater. Given that no major tributaries enter in the short distance between the West Creek confluence and the Taiya River streamgage, groundwater losses or gains appear unlikely to constitute a large part of the discharge at the Taiya River streamgage. The potential exists for small but ecologically important contributions of discharge to groundwater that sustains some mapping area wetlands, but this could not be quantified for this study.

The similarity in long-term average seasonal discharge patterns between the two streams is evident in an overlay of normalized mean daily discharge (mean daily discharge for the common period of record for each stream normalized by the mean annual discharge for the same period for each respective stream) (fig. 9). The Pearson's correlation coefficient ( $r$ ) computed for the logarithms of daily discharge of the two streams is 0.98 for the full common period of record, showing similarity also existed at a daily scale. For the seasonal subsets of this record, this daily scale correlation between streams is closest for the high flow season of May-October (Pearson's $r$ $=0.97$ ). West Creek daily discharge is proportionally higher and not as correlated with Taiya River flow from November to April $(r=0.90)$.

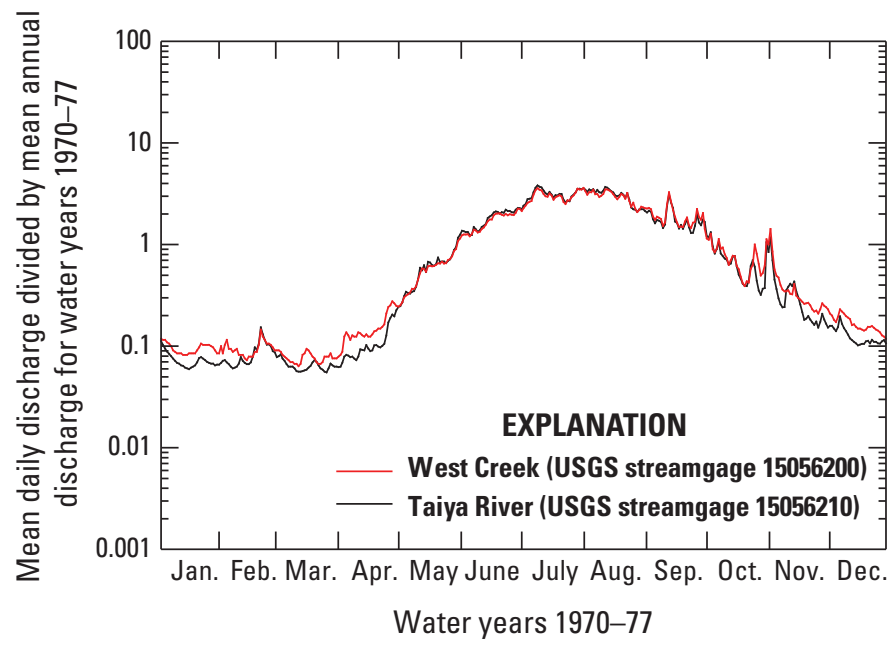

Figure 9. Normalized mean daily discharge for West Creek at U.S. Geological Survey (USGS) streamgage 15056200 and the Taiya River at USGS streamgage 15056210, Alaska, for the common period of record, water years 1970-77. The mean daily discharge is divided by the mean annual discharge for the common period of record for each respective stream.

\section{Large Floods Since the 1800s}

Within the available USGS records, the largest flood at both streamgages occurred in September 1967, when widespread heavy rains during September 14-15 dropped $130 \mathrm{~mm}$ of precipitation in Skagway and generated flooding across upper Lynn Canal (Boning, 1972). On the Taiya River, the flood discharge reached $708 \mathrm{~m}^{3} / \mathrm{s}$, which can be given a statistical annual exceedance probability (AEP) of about 0.5 percent, equivalent to a recurrence interval of $200 \mathrm{yrs}$ (using the weighted estimate from table 4 of Curran and others, 2016). On West Creek, the 1967 flood discharge reached $277 \mathrm{~m}^{3} / \mathrm{s}$, an AEP of 0.2 percent or a recurrence interval of 500 years (weighted estimate, table 4 of Curran and others, 2016). These statistical estimates of flood frequency were developed from the relatively short streamgage records and exclude glacial lake outburst floods (a 2002 gaged West Creek outburst flood and historical ungaged outburst floods), which do not occur regularly in response to meteorologic processes and therefore do not fit a population eligible for this statistical analysis. Flood effects recorded for the 1967 flood include extensive road repairs from Taiya River flood damage (Boning, 1972).

On July 23, 2002, a lateral moraine at the confluence of the two glacial valleys at the head of West Creek (fig. 1B), along with a section of the partly saturated, outwash-filled eastern tributary valley behind it, failed and discharged sediment-rich flow over the toe of the glacier and into the adjacent pro-glacial lake below (fig. 10A, $B$, and $C$ ) (Capps, 2004, Denton and others, 2005). The resulting outburst flood damaged property near the West Creek confluence and prompted the evacuation of the NPS campground along the Taiya River (fig. $10 D$ and $E$, respectively). The outburst flood discharge 


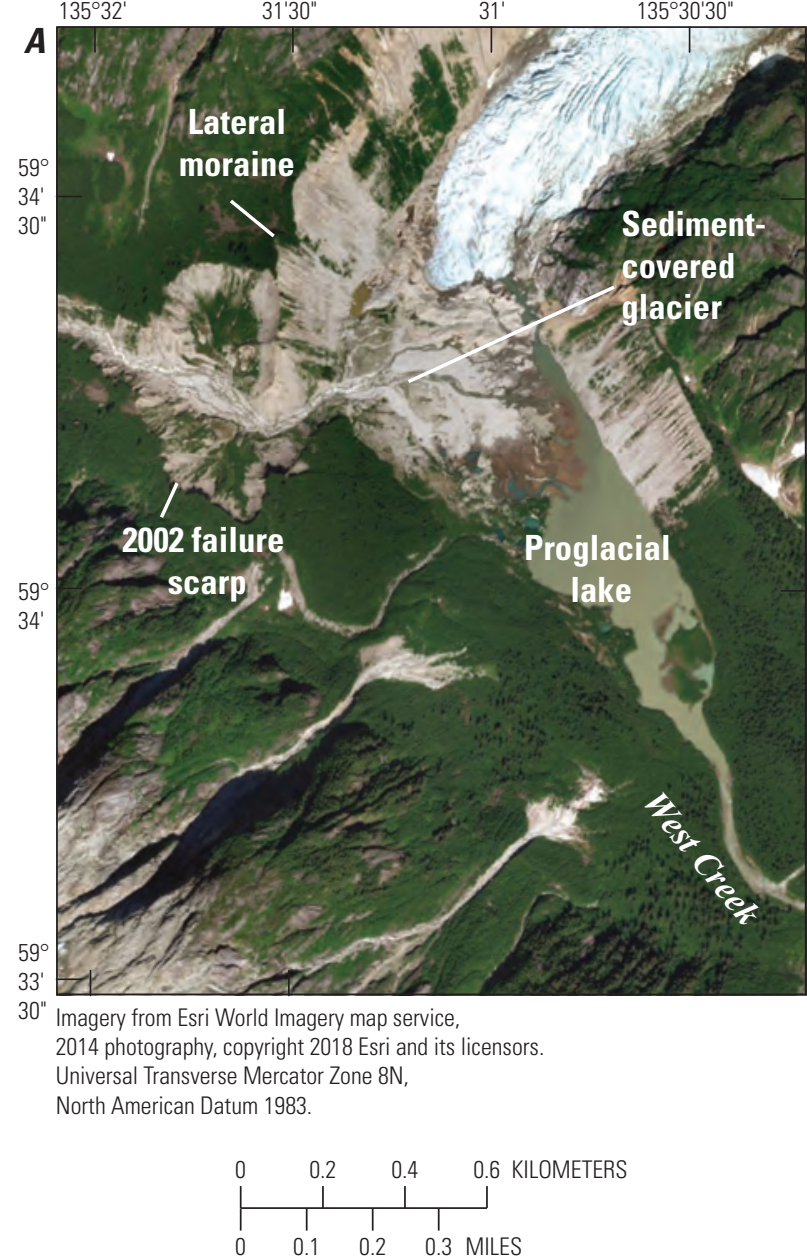

Figure 10. Orthophotograph and oblique aerial photographs showing 2002 West Creek glacial lake outburst flood setting and effects. $A, 2014$ orthophotograph showing location of lateral moraine and tributary valley failure, and sediment deposition over glacier and into proglacial lake. Aerial oblique photographs showing: $B$, failure scarp, perched tributary valley, and sediment spreading over the glacier (view west); $C$, sediment and ice debris in the proglacial lake (view downstream, West Creek in background); $D$, West Creek flooding into residential areas near the edge of the Taiya River valley bottom (upstream of the U.S. Geological Survey streamgage, fig. 3) and deposit of large woody debris at island heads; and, E, Taiya River flooding at parking area at downstream end of National Park Service campground. Photographs $B-E$ were taken July 23, 2002, by TEMSCO Helicopters, Inc. For reference, the location of a riprapped dike constructed along West Creek after 2002 is shown in $D$.
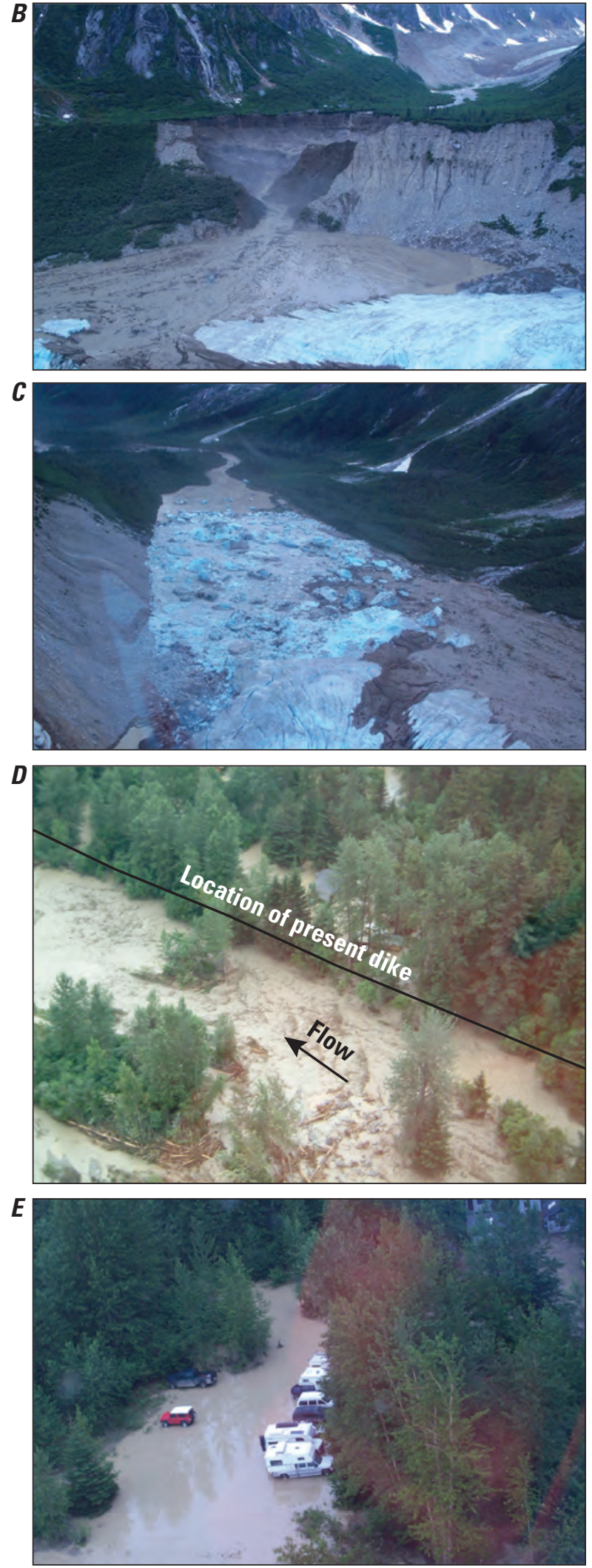
peaked at $527 \mathrm{~m}^{3} / \mathrm{s}$ at the Taiya River streamgage, forming the second largest peak in the Taiya River peak discharge record. A nonoutburst peak that size at the Taiya River streamgage would have had an AEP of about 2 percent (or a recurrence interval near 50 years). The West Creek peak discharge could not be determined at the streamgage location owing to flood damage and flooding outside the channel, but Capps (2004) estimated a peak discharge of $459 \mathrm{~m}^{3} / \mathrm{s}$ from comparison to pre-flood National Weather Service stage observations. The 2002 outburst flood peak discharge was much larger than that of the 1967 flood at the West Creek streamgage.

The pre-streamgage historical record for the Taiya River includes note of a large flood in the 1920s (Inglis and Pranger, 2002) that could not be verified for this report. For the nearby Skagway River, descriptive histories from the early 1900s until at least the 1990s note that an October 1943 flood was the largest flood in that period (Buzzell, 2004), exceeding the 1967 and 1981 floods that were the largest in the 1964-86 USGS Skagway River streamgage record. Given their late autumn dates, these Skagway River floods were likely driven by rainfall, which could have affected the Taiya River if regional in nature, a likely possibility for large rainstorms. A Skagway hazard mitigation planning document (Municipality of Skagway, 2009) notes a July 1953 flood that washed away the Matthews homestead cabin at Dyea and other cabins along West Creek. Cumulatively, these documents and data indicate that at least one other flood in the first half of the 1900s could have been on the order of the 1967 flood.

Older historical flood records include newspaper accounts of a September 18, 1897, flood in the upper Taiya River known as the Sheep Camp avalanche (Sacramento Daily Union, 1897; The Seattle Post-Intelligencer, 1897) or the Stone House Flood (Gurcke, 2010). The newspapers reported that observers at Sheep Camp along the upper Taiya River (fig. $1 B$ ) described a loud noise and sudden onset of a flow of what is variously described as water, or "land and rocks and ice" that swept away tents not on high ground, a toll bridge, and log footbridges. The flood was reported to have resulted in one fatality. Farther downstream at Finnegan's Point on the main stem of the Taiya River (fig. 2), observers noted that the "river rose nearly a foot in two hours." Most accounts described warm weather and heavy rains for a few days to weeks prior to the flood and attributed the flood to the formation of "a lake on the glacier" and a section of ice that broke off from the glacier upstream and west of the Stone House, a prominent large rock described as about $3 \mathrm{~km}$ upstream of Sheep Camp. The mention of a lake and the ice fracture, the locations of which are supported by Capps (2004), indicates the flood could have been a glacial lake outburst flood, and the description of the event as a slide or avalanche indicates the flood could have evolved into a debris flow. Although this flood locally affected discharge and sediment along the Taiya River upstream of the Taiya River main stem valley, it seems unlikely from historical and geomorphic evidence that it was large enough to create notable geomorphic effects on the Taiya River main stem.
More substantial glacial lake outburst floods emanated from the Nourse River valley prior to the Gold Rush. A historical map (Alaska Boundary Tribunal, 1904) depicts a glacier extending downstream of the last major tributary in the Nourse River valley and shows no lakes. However, tributary moraines in the valley bottom interpreted from IfSAR and aerial imagery, and the potential for large lakes to have drained during the Little Ice Age (Streveler, 1995), limit confidence in the Little Ice Age continuity of the valley glacier, which indicates that the series of dynamically changing valley-blocking tributary glaciers, moraines, and associated lakes in the valley bottom possibly was exposed earlier than the map depicts. Post and Mayo (1971) inventoried Alaska glacier-dammed outburst floods from historical aerial photography and mapped the Taiya River main stem as the inferred route of an undated glacier-dammed lake outburst flood originating from a lake midway up the Nourse River valley. Various informal studies (Streveler, 1995; Inglis and Pranger, 2002; Capps, 2004) have indicated that at least one large historical outburst flood resulted from a release of a glacial lake at the downstream end of the Nourse River valley. Streveler (1995) noted bouldery deposits between the mouth of the Nourse River and Finnegan's Point as potential evidence of outburst floods and presented tree-ring ages of 150 and 250 years before present for two surfaces downstream of the Nourse River confluence. He postulated a now-absent lake trapped by valley-blocking tributary glaciers in the Nourse River as a potential source for one or more groups of glacial lake outburst floods in that time frame. Collectively, these studies provide evidence of glacial lake outburst floods prior to streamgaging but do not specify whether the outburst floods occurred as isolated events or were recurring annual to multi-annual events.

The indicated influence of Nourse River glacial lake outburst floods on the geomorphology of the Taiya River main stem has not been comprehensively evaluated. An 1894 photograph looking down the main stem Taiya River (McArthur, 1894) shows a bare to lightly vegetated plain from the mouth of Nourse River canyon to about halfway to Finnegan's Point (fig. 11A), which has been interpreted by informal studies (Inglis and Pranger, 2002; Capps, 2004; Gurcke, 2010) to indicate denudation from an outburst flood not long before the photo was taken. Inspection of this photograph shows that the combined width of channels and unvegetated bars is wider, and the number of active channels more numerous, than in 2003 or 2014 orthophotos. Varying stages of vegetation can be seen on longitudinal wedges across the Nourse River fan. Within the limitations of the poor print reproduction of this photo, no accumulations of large woody debris indicative of valley-width-scale forest denudation can be detected. Although the number of flow paths has been reduced since 1894, the general locations of the Nourse River, upper Taiya River, and main stem Taiya River channels have been only slightly modified (fig. 11B). Inspection of 2003 lidar data shows that the Nourse River fan shape gradually diffuses downvalley, such that by about $1.5 \mathrm{~km}$ downstream, the elevation contours are roughly transverse to the valley. The upper Taiya River is 
A. 1894

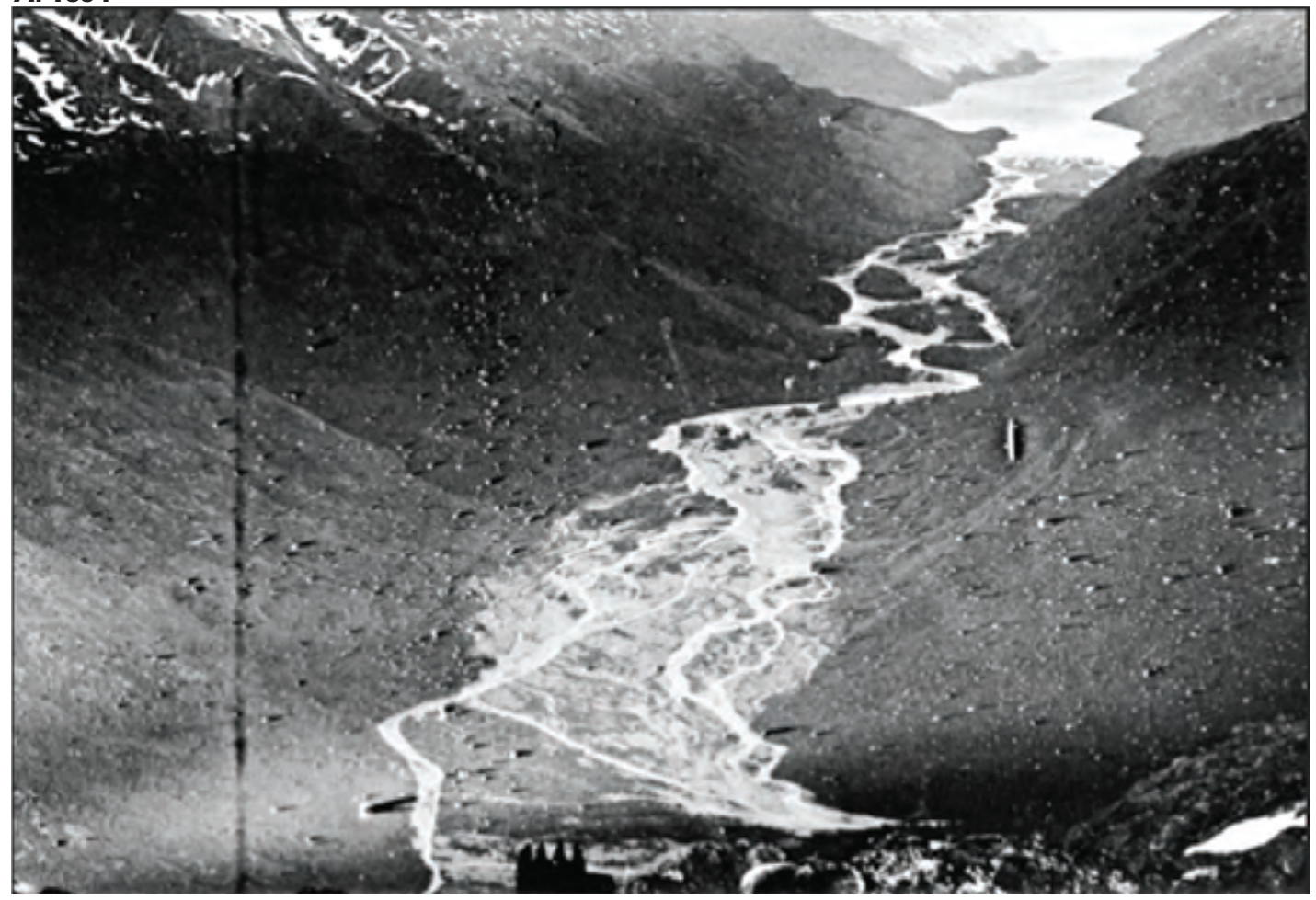

B. 2014

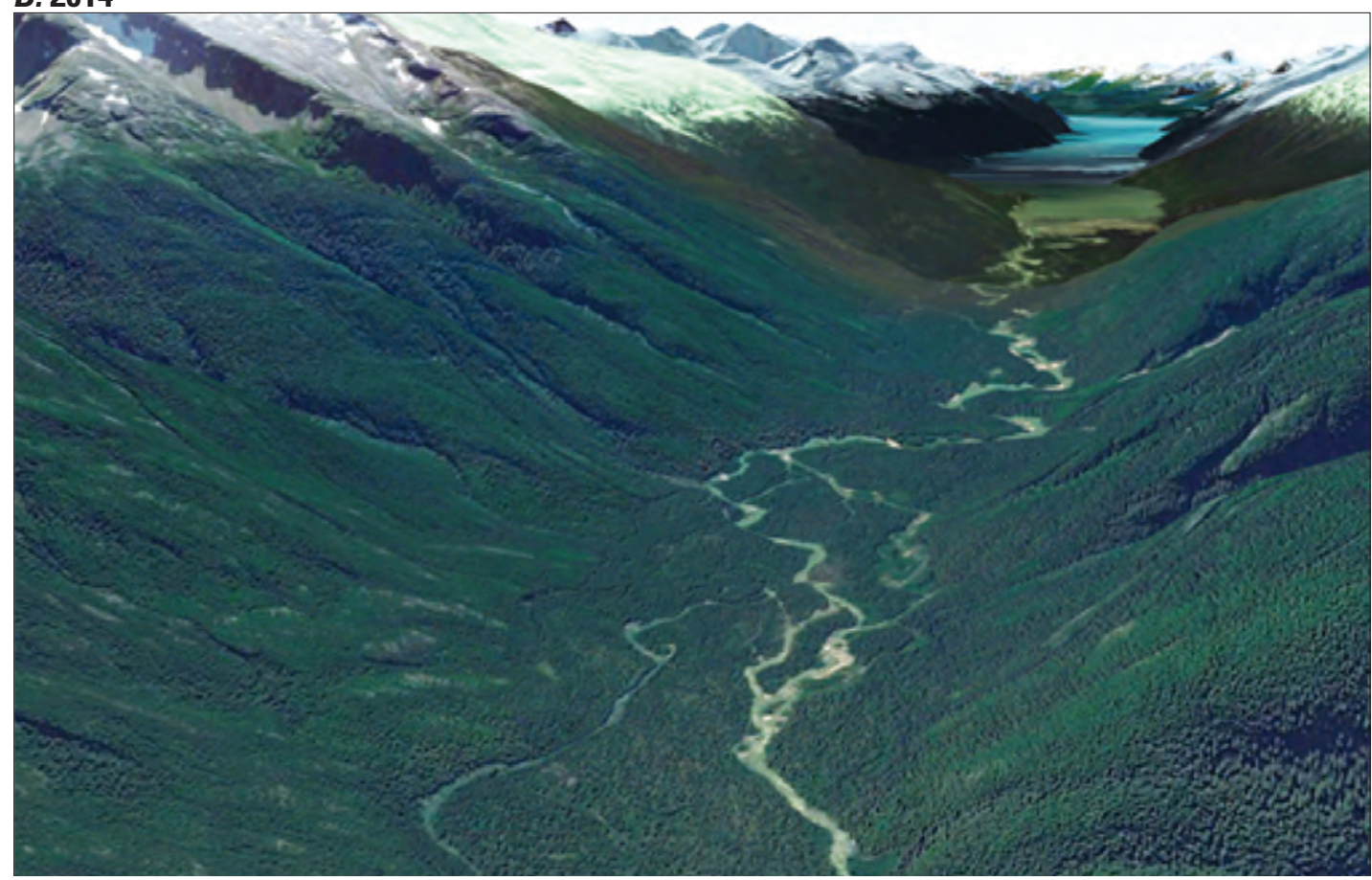

Figure 11. A, Historical aerial photograph looking south down the Taiya River, Alaska main stem taken in 1894 by J.J. McArthur for an international boundary survey. Artifacts from poor scan quality include apparent small lumps and shadows. Poor lighting in the foreground appears to show bare areas on side slopes that are known from other ground photographs to be forested. $B$, An approximate match of view location and angle using Google Earth to display 2014 Digital Globe imagery. The Nourse River enters the Taiya River main stem valley bottom from the right in the foreground, and Taiya Inlet is visible in the background. 
slightly incised into the distal margin of this fan. The surfaces lack prominent lobes, outsized bars, or current ripples that would indicate evidence of extremely large debris flows or outburst floods. The disparate ages obtained for abandoned fluvial surfaces (Streveler, 1995) indicate that channel mobility was episodic and not capable of reworking the entire valley bottom. Using these multiple lines of evidence, an alternative explanation to a large, catastrophic outburst flood for the bare appearance of the fan and downstream channels is a more active channel regime prior to 1894 , possibly supported by discharge of sediment directly into the Nourse River rather than into a lake or by frequent, smaller glacial lake outburst floods.

The chance of future glacial lake outburst floods, which pose a flooding threat to valley users and infrastructure and a possible influence on channel processes, depends in part on moraine stability. Bernatz and others (2011) reviewed available data on existing glacial lakes in the Taiya River Basin, including an unpublished 2007 survey that identified at least two lakes presenting potential outburst flood hazards in the Nourse River subbasin. An assessment of moraine structure determined that moraine stability did not present an outburst hazard at one of these lakes (Denton and others, 2009), but water displacement and lake outlet overtopping from sudden inputs at existing lakes, and glacial lake outburst flooding from new lakes formed during glacier retreat, remains a possibility in the Taiya River Basin.

\section{Suspended Sediment}

Collectively over the full period of record, the suspended sediment measurements captured information for a range of discharge magnitudes (fig. 12) and times of year (fig. 13). These measurements provide a basic characterization of the Taiya River Basin that is consistent with glacier-fed streams, where suspended sediment values range from winter background levels that are often high relative to nonglacier-fed streams to higher summer levels that fundamentally vary with discharge but can also vary substantially with a range of factors, including depletion of residual sediment stores and nonglacial processes within the basin (Jaeger and others, 2017).

Suspended sediment concentrations for the six discrete samples collected concurrently on West Creek and the Taiya River during WY2017-18 ranged from 13 to 162 milligrams per liter (mg/L) for West Creek and 6 to $284 \mathrm{mg} / \mathrm{L}$ for the Taiya River. The suspended sediment concentrations for a given discharge for the study period are slightly higher than the average for previous samples (fig. 12). The increase for the study period data relative to the 1960s and 1970s data is statistically significant in a t-test $(\mathrm{p}<0.05)$ for both streams. Although these increases signify some variation in sediment processes in the basin, the available data are too limited for trend analysis. The concurrent measurements for this study show that Taiya River suspended sediment concentrations spanned a slightly larger range of values than those measured in West Creek during WY2017-18 (fig. 12). The seasonal distribution of suspended sediment concentrations over the full period of record (fig. 13) was similar in both streams. In general, suspended sediment concentrations began to increase from relatively low winter levels in May, peaked in summer (June, July, or August), and declined throughout the autumn. The May-September 2017-18 measurements for both streams frequently had higher values than previous measurements. The 2017-18 and 2004 measurements for both streams and the 2004 measurements for the Taiya River collectively have earlier peak suspended sediment concentrations (June) than the 1960s (West Creek) and 1970s (Taiya River) measurements (August-September).

Discrete sediment sampling is often supplemented with continuous monitoring of turbidity, a related characteristic, to improve understanding of sediment conditions. Here, plots of turbidity monitoring data collected by SEAN (Sergeant and Johnson, 2018) during the study period showed seasonal patterns that were generally consistent with the suspended sediment measurements. Daily mean turbidity increases around May and remains relatively high throughout the summer and early autumn. The daily mean turbidity never dropped below 13 nephelometric turbidity units (NTU) during the month of July between 2011 and 2017, for example, and spiked briefly several times a year to a period-of-record maximum of 1,930 NTU. Spikes in daily mean turbidity to a maximum of nearly 400 NTU in 2017 were noted to generally coincide with high flow (Sergeant and Johnson, 2018). The strongly fluctuating nature of the turbidity data indicates that suspended sediment fluctuates on an hourly to daily scale in the Taiya River Basin, a common characteristic of glacier-fed streams.

\section{Geomorphology}

The formation of the Taiya River valley was strongly affected by bedrock and structural geology, which established the framework within which geomorphic processes can operate. The valley owes much of its narrow, steep-sided form and straight orientation to the erosion of fault-weakened bedrock (Gehrels, 2000; Wilson and others, 2015). Geomorphic processes, largely glacial and fluvial, were responsible for filling the presently flat-floored valley bottom with sediment and leaving a legacy of features that presently facilitate or constrain fluvial processes. Abandoned channels visible in the REM map of the main stem valley bottom (fig. 14) show that the Nourse River near the head of the valley and the Taiya River elsewhere have moved across most of the valley except where constrained by fans. 


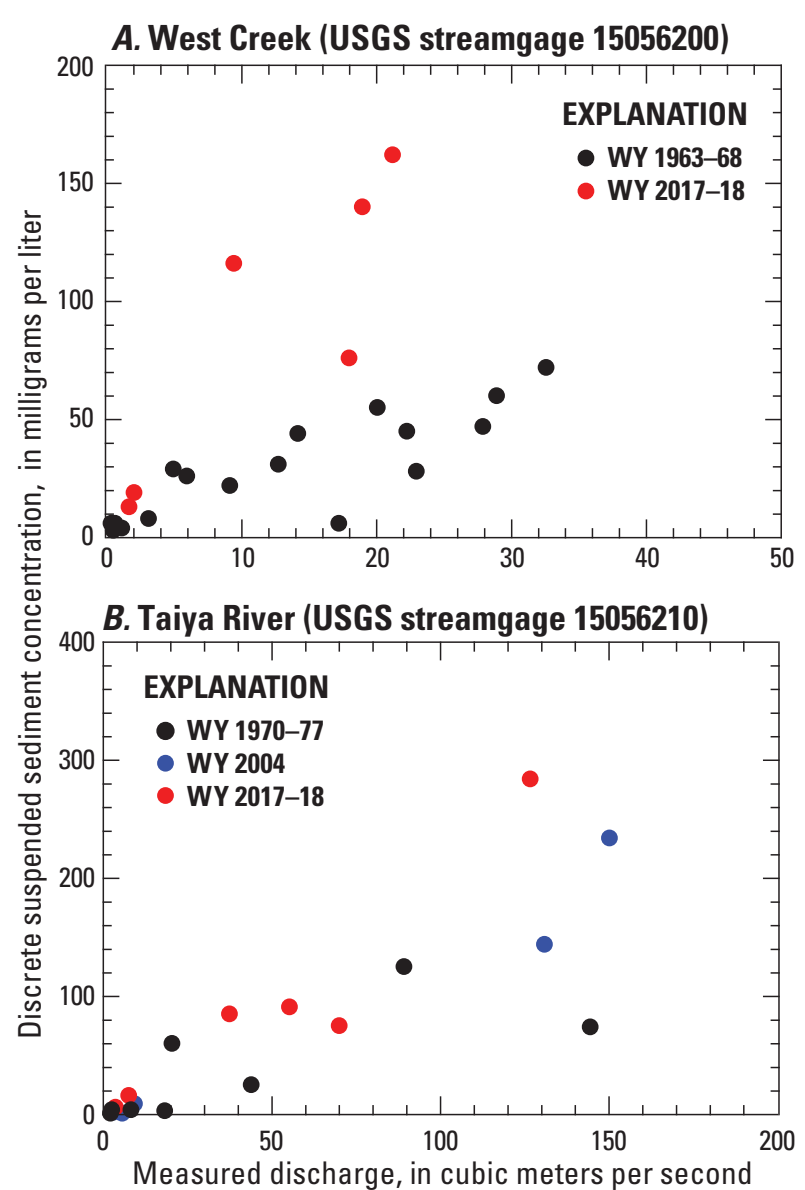

Figure 12. Discrete suspended sediment concentration in relation to measured discharge at U.S. Geological Survey streamgages, $A$, West Creek (15056200) and, B, Taiya River (15056210), Alaska, during periods of record. [WY, water year]

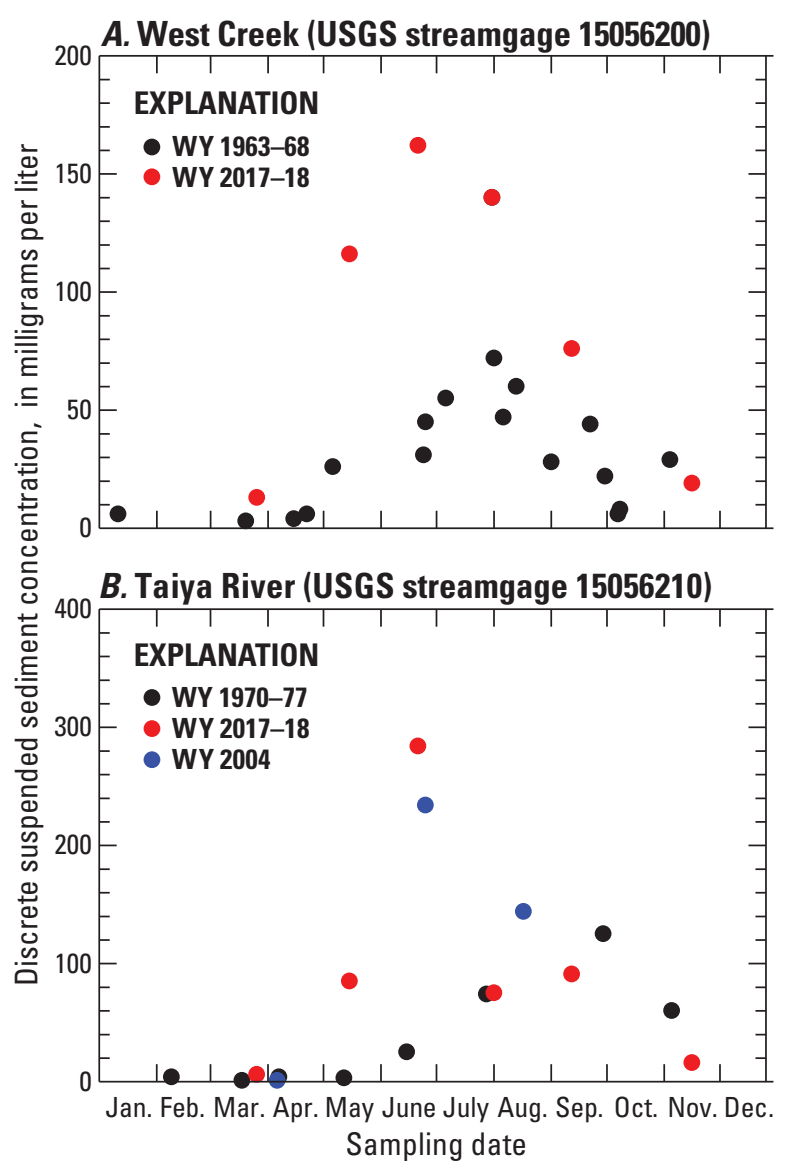

Figure 13. Discrete suspended sediment concentration by month and day of sampling for U.S. Geological Survey streamgages, $A$, West Creek (15056200) and, $B$, Taiya River (15056210), Alaska, during periods of record. [WY, water year] 


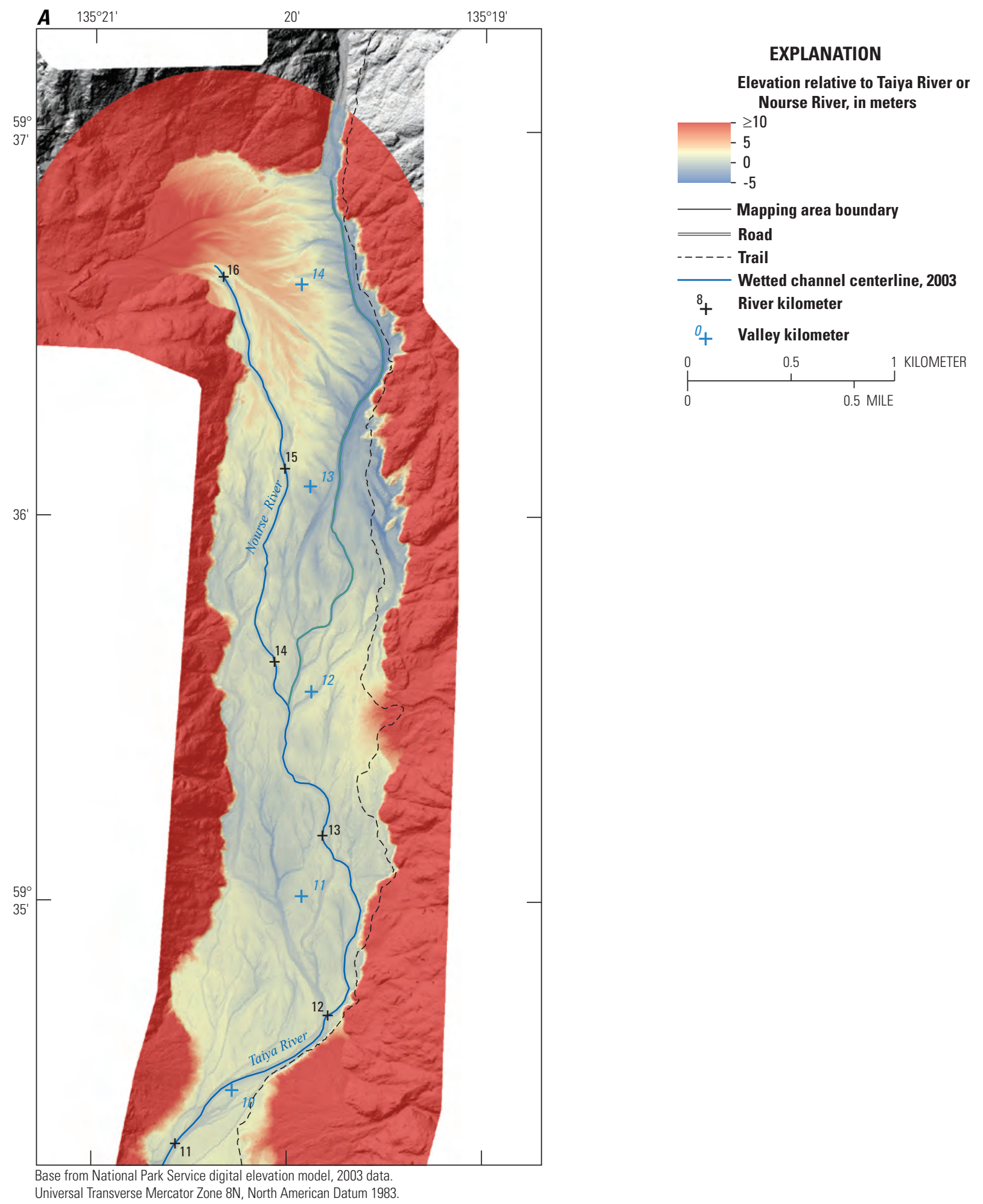

Figure 14. Relative elevation model of the Taiya River main stem valley bottom showing height above the water surface of, $A$, Taiya River and Nourse River, B, Taiya River, and C, Taiya River, Alaska, for 2003 conditions. 

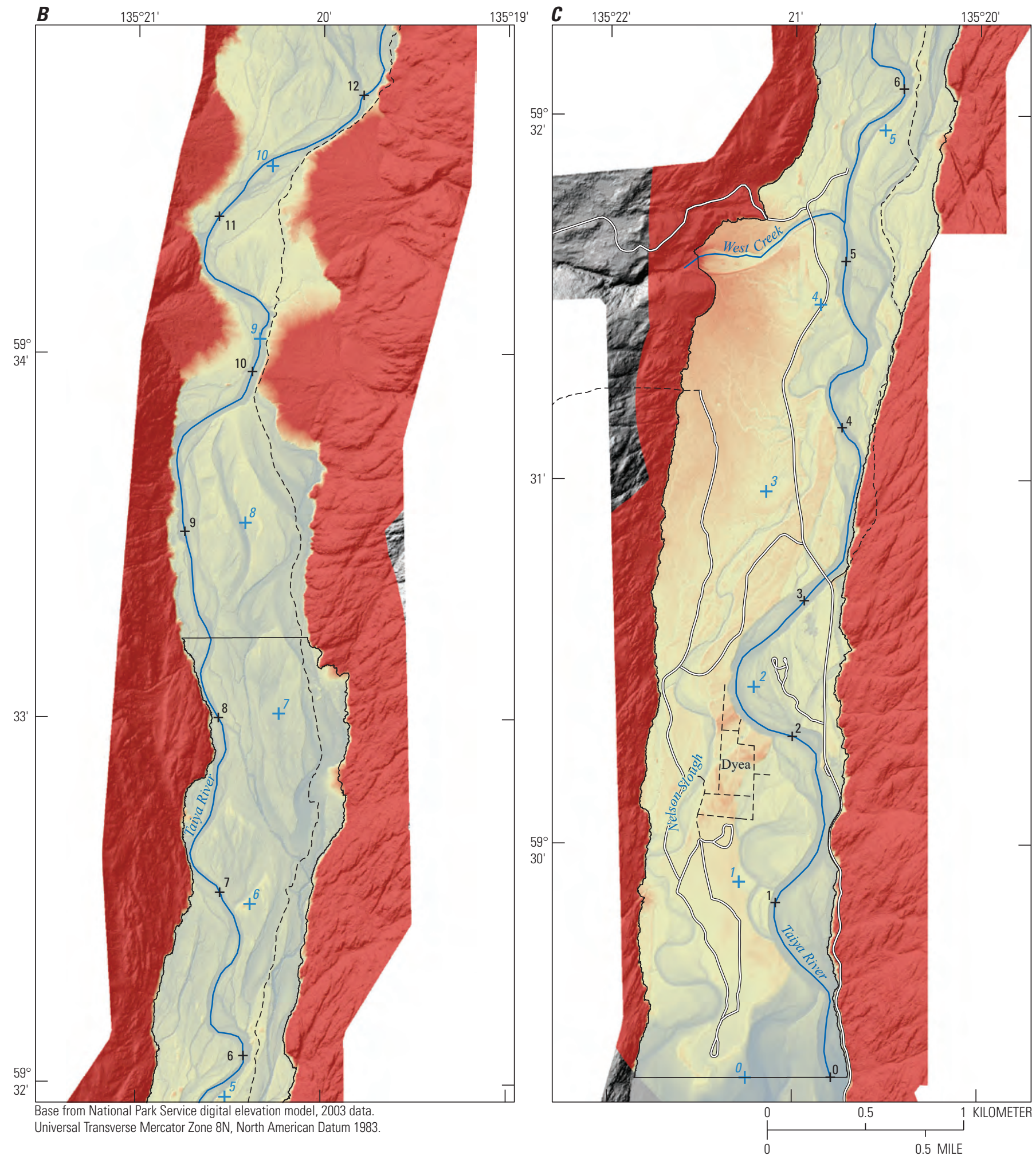

Figure 14.-Continued 
Within the mapping area, a mosaic of fluvial deposits of varying age and origin extend downstream to recently uplifted tidal flats. An overview of the surface mapping units (by formative process without relative ages) and off-mainstem channels is shown in figure 15. Geomorphic surfaces and off-main-stem channels are described and shown in more detail in the "Valley and Main Stem Channel Geomorphology" and "Off-Main-Stem Channels" sections and documented as boundaries and attributes in a data release (Curran, 2020; see also appendix 1 GIS digital files available at https://doi. org/10.5066/P9XP1SE7).

\section{Valley and Main Stem Channel Geomorphology}

The Taiya River main stem valley bottom maintains a relatively constant width from its head near the Nourse River confluence to the West Creek confluence, where it abruptly widens (figs. 14, 15, and 16). Within the mapping area, this width is an average of $720 \mathrm{~m}$ upstream of West Creek and 980 $\mathrm{m}$ downstream of West Creek, as measured at $0.5-\mathrm{km}$ intervals (fig. 16). The valley bottom is confined by bedrock walls except where tributary streams have formed high-angle alluvial fans, the most prominent of which are four closely spaced tributary fans, two on each side of the valley, at Finnegan's Point (figs. 2 and 14) upstream of the mapping area. The steep Nourse River alluvial fan fills the head of the valley bottom, obscuring any fan from the upper part of the Taiya River, and a low-gradient fan from West Creek extends partway across the valley bottom. Active main stem channel gradients are steepest, exceeding 0.02 meter per meter $(\mathrm{m} / \mathrm{m})$, in the Nourse River at the head of the Nourse River fan and decrease quickly downstream, dropping below $0.01 \mathrm{~m} / \mathrm{m}$ at the confluence of the Nourse and Taiya Rivers and below $0.005 \mathrm{~m} / \mathrm{m}$ by Finnegan's Point.

The channel planform of West Creek, Nourse River, and Taiya River as of 2014 (the date of the most recent imagery for the full mapping area) was generally single channel with mid-channel and lateral bars, small vegetated islands, and a few long sloughs. The exception to this is a $3-\mathrm{km}$ anastomosing (stable multiple-channeled) reach at the head of the Taiya River valley (fig. 2). Locally, the valley wall or large alluvial fans control the Taiya River channel location, creating short reaches with a particularly straight bank in planform where the channel flows against the bedrock valley wall at VK 3.0, 6.0, and 7.0 (fig. $14 B$ and $14 C$ ), and a bend at the paired fans at Finnegan's Point (fig. 14B, VK 9.0 and 10.0), respectively. Where not constrained, the stream has formed shorter-radius bends in a meander belt no more than $250 \mathrm{~m}$ wide upstream of the Taiya River bridge and larger-radius meanders in a meander belt about twice as wide downstream. The largest meander bend, more than $500 \mathrm{~m}$ in amplitude, extends halfway across the valley bottom at VK 2.0, the location of the NPS campground and Dyea townsite (fig. 3). The Taiya River reaches mean higher high-tide elevation near the Dyea townsite and mean sea level at about VK 0.5, downstream of which the river floods broadly at high tide but drains in meandering, tidally and fluvially influenced channels at low tide.

Within the mapping area, geomorphic units include active and abandoned main stem Taiya River surfaces, each subdivided into two relative ages; alluvial fans from West Creek and smaller tributaries; and tidal flats transitioning to upland surfaces (fig. 17). These units are described in the following subsections.

\section{Active Main Stem}

The active main stem mapping unit includes areas active in 2003 plus small adjacent areas converted to active main stem by erosion by 2018 (fig. 17). Examples of 2017-18 conditions along West Creek and the Taiya River are shown in figure 18. The width of the active channel, which includes channels, bars, and islands, within the mapping area averaged $100 \mathrm{~m}$ upstream of West Creek and widened to $170 \mathrm{~m}$ downstream, as measured at $0.5-\mathrm{km}$ increments. The channel slope averaged $0.0022 \mathrm{~m} / \mathrm{m}$ over the mapping area but decreased downstream, averaging $0.0029 \mathrm{~m} / \mathrm{m}$ from the upstream end of the mapping area to a slight flattening of slope at VK 3.5 and $0.0015 \mathrm{~m} / \mathrm{m}$ from VK 3.5 to the downstream end of the mapping area. The sinuosity, or channel length relative to valley length, is 1.1 for the mapping area.

Grain sizes on bars or visible in the channel within the mapping area exceeded cobbles, defined as a maximum of $256 \mathrm{~mm}$, only at the West Creek valley margin, where large boulders form a cascade at the valley margin and scattered boulders are present for about $300 \mathrm{~m}$ downstream. Bars along West Creek near its mouth and along the Taiya River consist chiefly of gravel (defined as greater than $2 \mathrm{~mm}$ to a maximum of $64 \mathrm{~mm}$ ) to cobbles with varying amounts of sand. As a general indication of relative grain size between West Creek and the Taiya River, and with distance downstream along the Taiya River, the diameters of the particles estimated by a visual scan as the median size $\left(\mathrm{D}_{50}\right)$ at the heads of bars in West Creek near the mouth (VK 4.5), the Taiya River upstream of West Creek (VK 4.8), and the Taiya River near the mouth (VK 1.6) were in the gravel range $(45 \mathrm{~mm}, 64 \mathrm{~mm}$, and $23 \mathrm{~mm}$, respectively, to the nearest half phi scale class). Finer deposits included fresh sand to gravel deposits over partly vegetated bars and sand ripples more than $0.3 \mathrm{~m}$ thick on one backbar channel. More formal particle-size measurements would be required to accurately quantify $\mathrm{D}_{50}$ for analysis purposes or to document the range of sizes present. 


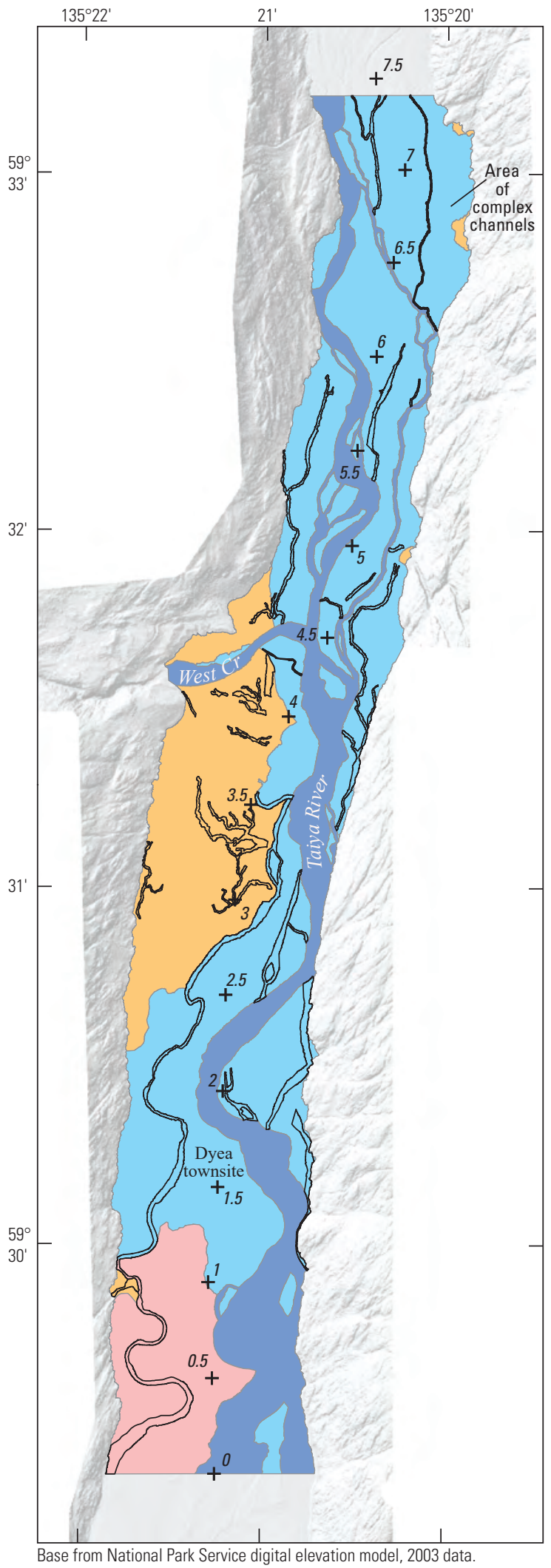

EXPLANATION

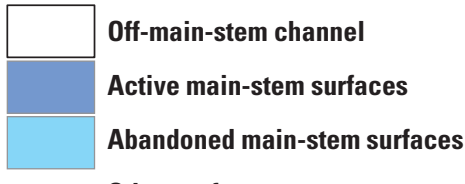

Other surfaces

Alluvial fan

Emergent tidal flat

+6.5 Valley kilometer

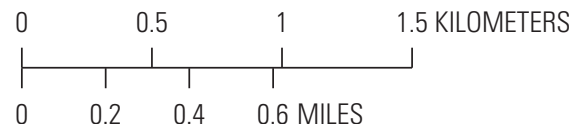

Universal Transverse Mercator Zone 8N, North American Datum 1983

Figure 15. Geomorphic surfaces by formative process and off-main-stem channels of the lower 7.5 kilometers of the Taiya River valley bottom, Alaska. 

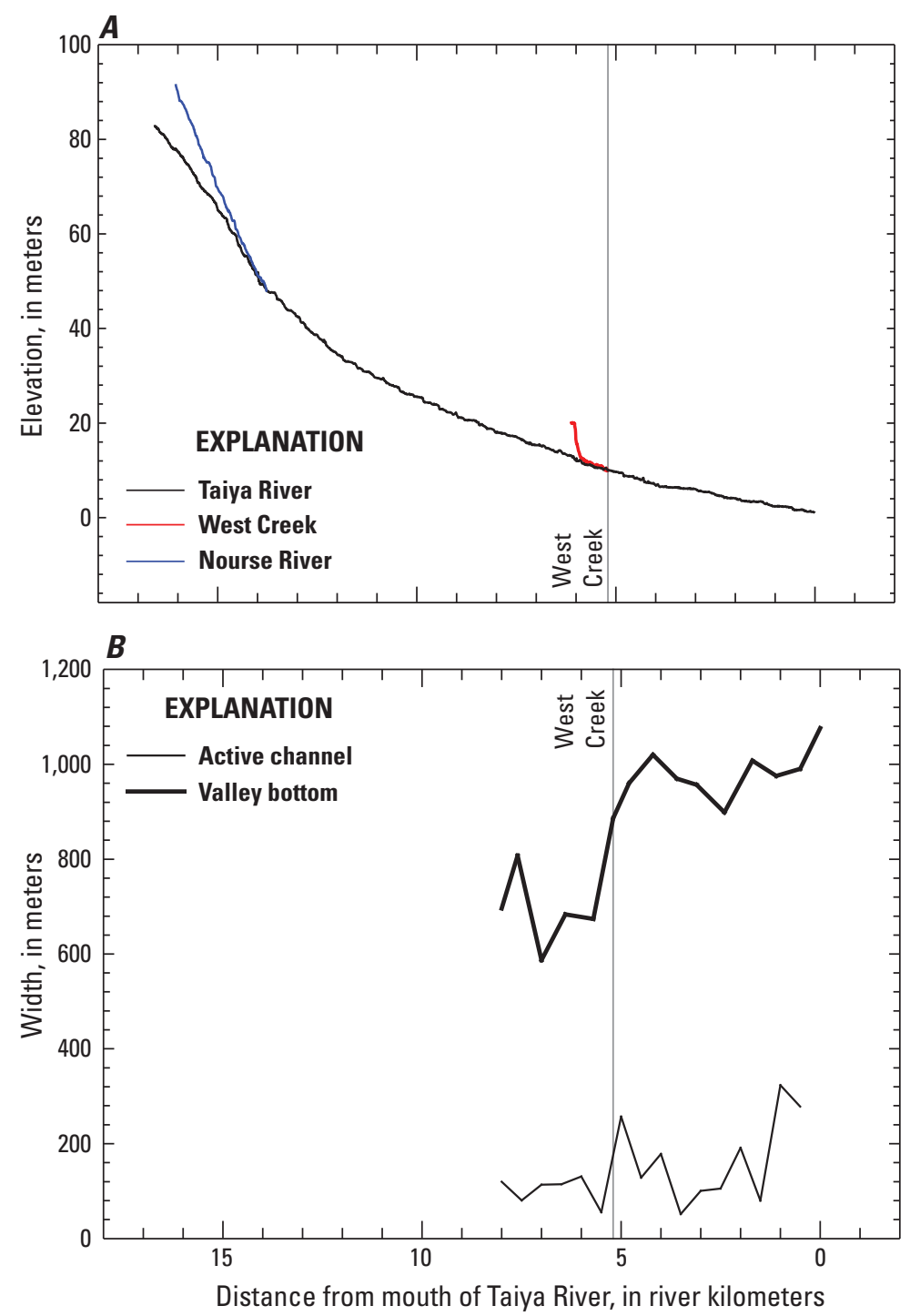

Figure 16. A, Stream longitudinal profile for the Taiya River and major tributaries within the Taiya River main stem valley, Alaska, from 2003 lidar data and, $B$, active Taiya River channel and valley bottom widths within the mapping area. The stream centerline used to generate the profile is shown in figure $14 A, B$, and $C$. 


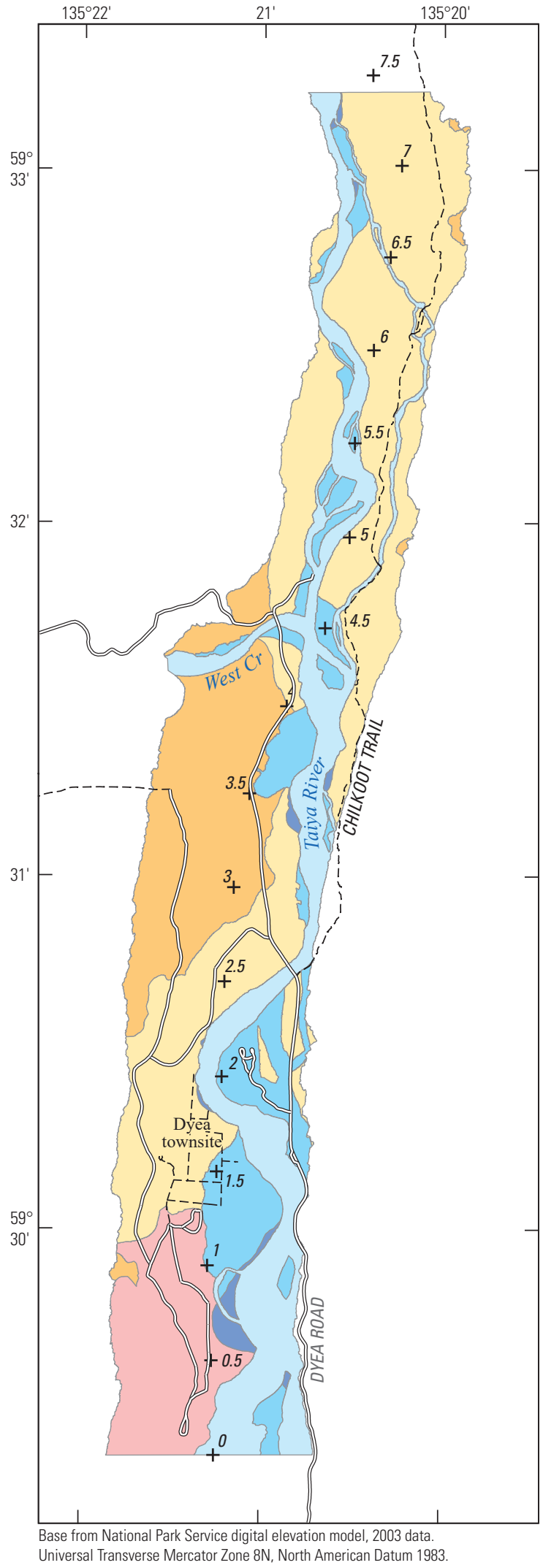

\section{EXPLANATION}

Active main-stem surfaces

Main stem activated between 2003 and 2018

Main stem active in 2003

\section{Abandoned main-stem surfaces}

Main stem abandoned between 1940s and 2003

Main stem abandoned prior to 1940 s

Other surfaces
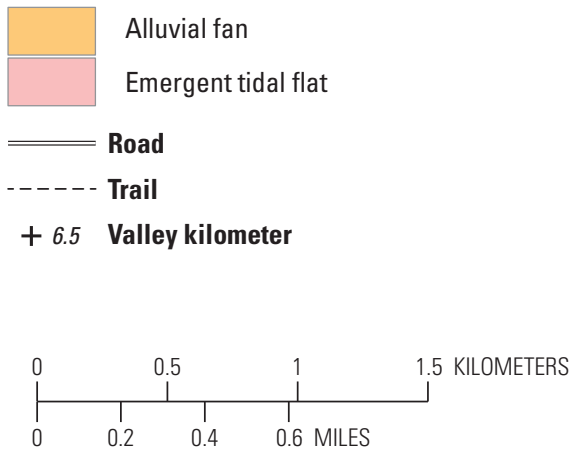

Figure 17. Geomorphic map of the lower 7.5 kilometers of the Taiya River valley bottom, Alaska, showing geomorphic surfaces by formative process and relative age. 

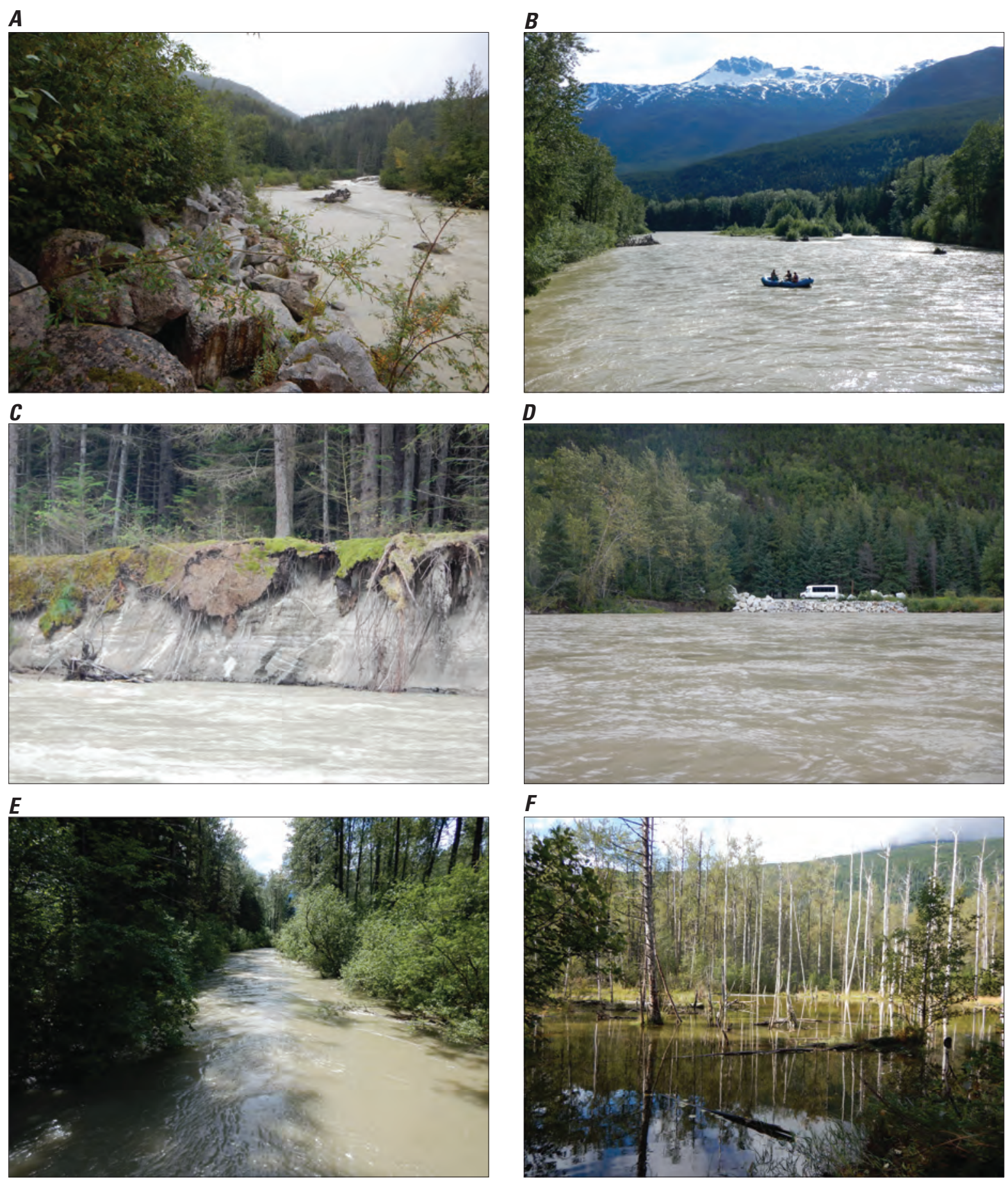

Figure 18. West Creek and Taiya River features, Alaska. Photographs from top left: $A$, view upstream along West Creek, showing riprap along the right bank, August 31, 2017; $B$, view downstream along the Taiya River from the Dyea Road bridge, showing recreational rafters, large woody debris, and mid-channel bars, June 19, 2018; $C$, erosion of the right bank in the large meander at valley kilometer (VK) 2.0 actively affecting the Dyea townsite, August 30, 2017; $D$, riprap protects an eroding section of the left bank adjacent to the National Park Service campground, VK 2.0, August 30, 2017; E, view downstream along the VK 4.5-7.0 slough from the Chilkoot Trail crossing at VK 5.0, June 19, 2018; and F, a large pond at the downstream end of a beaver pond complex at VK 5.5, August 30, 2017. All photographs taken by Janet H. Curran, U.S. Geological Survey. 
Except where the river borders the bedrock valley wall (fig. 17), Taiya River banks are composed of easily erodible unconsolidated sediments consisting largely of sand and gravel. Well-exposed eroding banks at VK 2.0 (fig. 18C) are mostly sand with occasional gravel and are partially lined with large woody debris. Bank heights downstream of West Creek are typically 1-2 $\mathrm{m}$ above the typical summer water surface and a maximum of about $5 \mathrm{~m}$. Bank heights are particularly low (less than $1.5 \mathrm{~m}$ ) adjacent to low terraces shown as surfaces abandoned between the 1940s and 2003 at VK 3.5-4.0 and VK 1.0-1.5 (figs. 14 and 17). The tallest banks exceed 2.5 $\mathrm{m}$ for almost $1 \mathrm{~km}$ along the right bank (looking downstream) in the large meander at VK 2.0 and for less than $100 \mathrm{~m}$ at the Taiya River bridge where the channel flows along surfaces abandoned before 1948 .

The 2003 aerial imagery and study field observations show that the active main stem usually includes a prominent main channel and additional features that introduced channel complexity, including lateral and mid-channel bars and backbar channels. Vegetated islands were most common upstream of and at the West Creek confluence and consisted entirely of former channels abandoned between the 1940s and 2003 (fig. 17). The Taiya River has relatively few sloughs but has historically maintained them on a decadal scale. Presently, in addition to a long slough in the northern half of the mapping area (VK 4.5-7.0), which is about $15 \mathrm{~m}$ wide and conveys substantial main stem flow (fig. 18E), a smaller slough at VK 1.0 extends several hundred meters across abandoned fluvial surfaces near the river mouth (fig. 17).

Large woody debris observed in the active Taiya River throughout the mapping area consisted of tree sections or intact trees with branches and rootwads stranded as individual pieces or part of accumulations (log jams). Trees were observed lodged in the bed in mid-channel, attached to a bank and protruding into the channel, and deposited on bars or at the mouths of back-bar channels or sloughs. Large jams were present upstream of West Creek. Inglis and Pranger (2002) documented relict log jams buried in banks and large woody debris lining banks near Dyea. The minimal amount of large woody debris along the Dyea banks at the time of this study and the presence of relatively fresh (branches intact) large woody debris elsewhere indicates that wood recruitment is active and wood mobility possible under present flow conditions.

\section{Abandoned Fluvial Surfaces}

The Taiya River has abandoned former channel areas within the mapping area via channel migration or avulsion. The abandoned fluvial surfaces have retained channel definition expressed topographically (fig. 14) or through vegetation type and relative maturity for decades, with decreasing feature definition with age. The more recently abandoned surfaces in the study, those surfaces active or lightly vegetated in 1948 or later but abandoned by 2003, now consist of a suite of inactive channels and bars that are often distinct and extend across much of the abandoned surfaces. Vegetation ranges from grasses and shrubs to young forests, depending on time since abandonment and environmental conditions including tidal inundation. Curvilinear breaks in vegetation at former channels are distinct. Older abandoned fluvial surfaces, likely abandoned prior to the 1940s given the level of vegetation by 1948 , consist of a mosaic of inactive channels and bars that are less distinct than those on younger abandoned surfaces. Individual channel banks or bar forms can be discerned but generally are not continuous except where tributaries or sloughs have maintained surface flow after surface abandonment. Upstream of VK 5.5, several major former flow paths of the suite of main stem channels active in 1894 can be discerned from elevation data (fig. 14). Older abandoned surfaces are typically fully vegetated and often fully forested. The history of logging and clearing in the Taiya River valley in the past century has affected vegetation age and structure, but fluvial surface topography is still discernible as sometimes subtle curvilinear changes in vegetation along former channels.

\section{Alluvial Fans}

Alluvial fans form prominent to subtle disruptions in the otherwise relatively consistent downvalley slope of the valley bottom. Formed where steeper tributary streams enter the main Taiya River valley and deposit coarse sediment in response to the change in gradient, these fan-shaped fluvial deposits vary in size and steepness depending on the size, gradient, and sediment supply of their tributary streams.

The largest alluvial fan within the mapping area, the West Creek fan, is a low-angle (down-fan gradient less than 0.01), diffuse feature that extends more than halfway across the Taiya River valley bottom and about $2.5 \mathrm{~km}$ along the valley bottom (VK 2.2-4.8; fig. 17). West Creek flows through a long, narrow, relatively low-angle valley before entering a narrow bedrock canyon then debouching onto the fan. West Creek presently flows across the northern end of the fan (fig. 3) in a single channel but flooded onto inactive fan areas during the 2002 glacial lake outburst flood, prior to bank reinforcement (fig. 10). Notably, no large channels comparable to the present size of West Creek appear on the abandoned West Creek fan. The fan displays only minor trimlines from the Taiya River.

Several smaller tributaries, including Nelson Creek at VK 1.0, have formed smaller, steep fans that protrude a short distance (less than $150 \mathrm{~m}$ ) from the valley wall (fig. 17). Even smaller tributaries draining the valley walls have created or maintained channels across the valley bottom but have not formed fans mappable at the scale of this study. 


\section{Emergent Tidal Flats}

Near the river mouth (fig. 17), low surfaces that were below the high tide line during the Gold Rush of the late 1800s have been subsequently uplifted by the rapid isostatic rebound of southeast Alaska (Larsen and others, 2005). These uplifted intertidal areas have not been fluvially reworked by the main stem Taiya River, resulting in relatively smooth surfaces lacking major channel forms (fig. 3). Smaller features present include small channels and ridges likely associated with tidal currents and coastal aeolian processes. Vegetation consists mostly of grasses and salt tolerant plants. Conifers have begun to disperse downvalley as land rises, creating a young, sparse forest with a strong downvalley age gradient at the upstream end of the mapped emergent tidal flat surface.

\section{Historical Channel Change}

Abandoned fluvial features fill the width of the main stem valley bottom, documenting the historical mobility of the Taiya River. Within the mapping area, topographic evidence of relict assemblages of long, downvalley-oriented, curved channels; shorter, cross-valley channels; and intervening bars in some locations indicate the river formerly had multiple channels that were free to migrate or braid. Dendritic patterns superimposed on some abandoned main-stem surfaces indicate that these surfaces stabilized long enough to develop small channel networks conveying groundwater discharge or tributary flow. Wide swaths of abandoned channels inset into adjacent surfaces indicate that the active river was wider in the past. Downstream of West Creek, a history of meandering can be seen in a meander belt developing along the eastern side of the valley. Photographic evidence from 1894 and 1948 show specific channel changes and indicate a reduction in mobility since the late 1800 s.

\section{Channel Change 1894-1948}

Photographs from 1894 (table 1) show a series of forested islands in a nearly valley-wide active channel throughout much of the Taiya River valley bottom (figs. $11 A$ and $19 A$ ). Relative to modern conditions (figs. $11 B$ and $19 B$ ), the Taiya River valley bottom was considerably less vegetated, supported more channel pathways, and had wider active channel belts within those paths. Although the specific cause of change is unclear, the river was more actively shifting channels and braiding in some locations at some time prior to 1894. During the Gold Rush, the Taiya River maintained two major branches in the Dyea area; the channel known as the West Branch Taiya River and later as Nelson Slough was a substantial active channel at the time. An oblique photo from the ridge above Dyea (Beirely, 1917) shows that as late as 1917, the Taiya River actively braided through a wide belt including lightly vegetated abandoned surfaces on the eastern side of the valley, but the smaller, single-thread Nelson Slough occupied a position close to its location in 1948 and all subsequent aerial photography (table 2). By 1948, the active Taiya River channel belt had narrowed considerably, abandoning major channel pathways and reducing the stream to the single main channel pathway still occupied in 2019 (figs. 3 and 17). Multiple meander scars and the 1948 channel location between VK 1.0 and 1.5 (area of abandoned surfaces in fig. 17) document active meander migration in the lowermost reaches of the river prior to 1948 .

\section{Channel Change Since 1948}

In the second half of the 1900s, reduction in size and activity of the channel continued. Compared to 1948 conditions, the Taiya River has maintained the same general location within the mapping area but consolidated from multiple channels and frequent bars within a small active channel belt to a mostly single-thread channel with fewer bars and an even narrower active channel belt. Since 1948, channel change consisting mostly of meander migration and meander cutoffs affected areas downstream of West Creek, slightly widening the modern meander belt and creating abandoned fluvial surfaces (figs. 17, 20, and 21). Other minor channel adjustments, mostly development of small meanders, occurred upstream of West Creek. Many individual gravel bars elongated, shifted, or changed in size but have not changed position since at least 1948. Since 2003, relatively little change has occurred to the Taiya River channel location. Between 2003 and 2018, the Taiya River eroded a total area of $0.07 \mathrm{~km}^{2}$, or less than 1 percent of the active channel area. Erosion occurred throughout the mapping area (fig. 17), extending a maximum of 150 $\mathrm{m}$ into the bank and spanning reaches mostly less than a few hundred meters long but also including a nearly $1-\mathrm{km}$-long reach at VK 1.0.

The location of the West Creek channel within the mapping area has remained essentially fixed upstream of the West Creek bridge since 1948. Riprap bank protection, placed in association with bridge construction and following the 2002 glacial lake outburst flood, enforces the path (fig. 18A). Immediately downstream of the bridge, however, West Creek migrated north after 1948, contributing to erosion of a bar separating the channels that forced stream capture of a section of West Creek by the Taiya River (fig. 21). The complex channel changes that ensued rearranged the Taiya River, effectively straightening a kilometer-long reach and moving the confluence about $200 \mathrm{~m}$ upstream. 


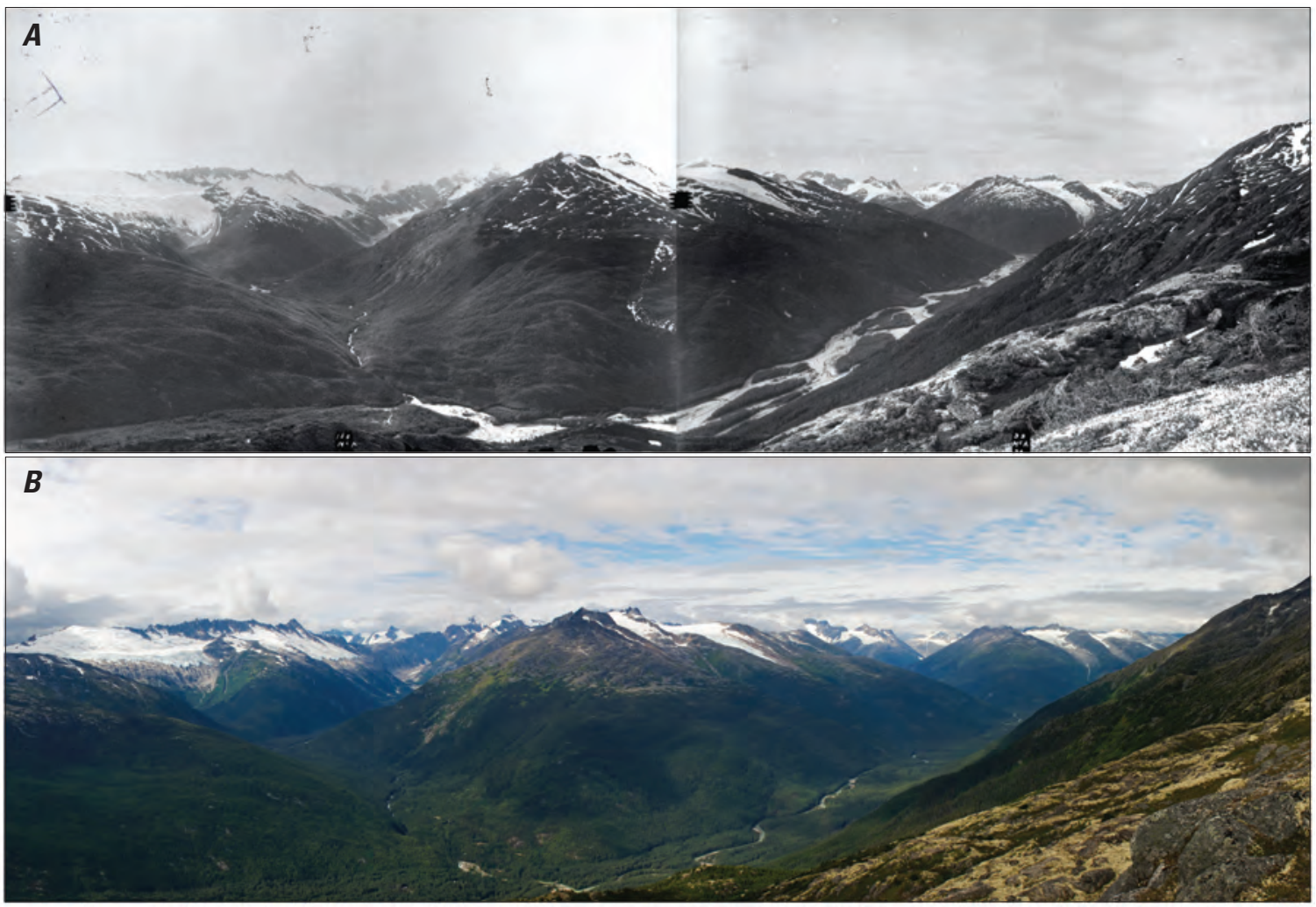

Figure 19. Photographs from Klondike Gold Rush National Historical Park photo station $\mathrm{CH}-14$ looking west toward West Creek from AB Mountain above the Taiya River valley, Alaska. A, 1894 conditions show multiple main stem flow paths containing wider suites of active channels. $B$, August 27, 2013, conditions show the active main stem channel has consolidated into a single flow path and narrowed. Photographs, $A$, by James J. McArthur, International Boundary Commission and, B, by R.D. Karpilo, Jr., National Park Service. Modified from AB Mountain 1 Photo Pair, Chilkoot Trail: Then and Now photo gallery, National Park Service website https://www.nps.gov/klgo/ learn/nature/repeatphotography.htm. 


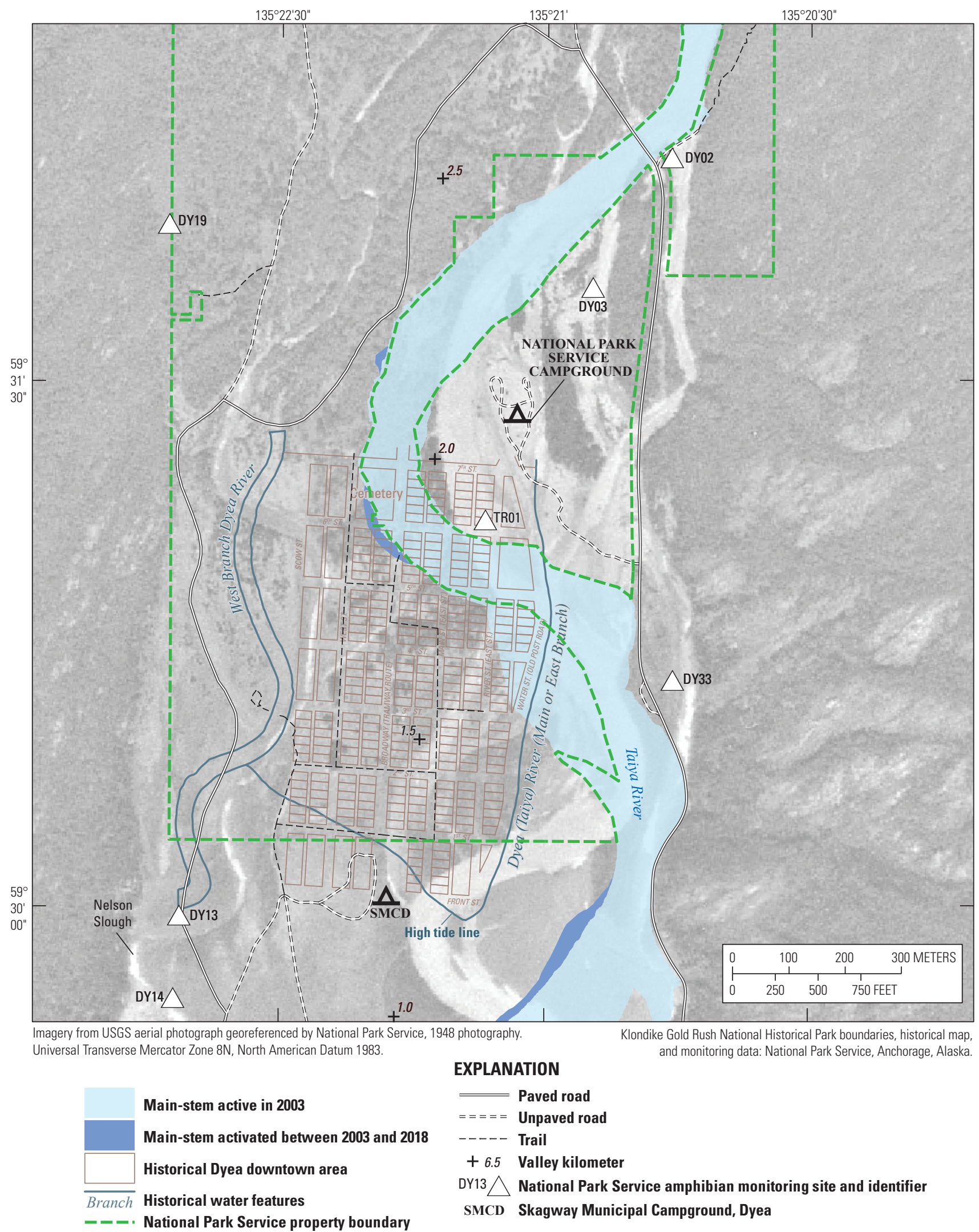

Figure 20. Changes to the active main stem of the Taiya River between 1948 and 2018 near the Dyea townsite, Alaska. The historical map of Dyea shows the locations of downtown lots and streets and the approximate locations of the West Branch Dyea River (now Nelson Slough), the Main or East Branch of the Taiya River (now Taiya River), and the high tide line during the Gold Rush (1897-98). Channel patterns in the 1948 aerial photograph indicate that channel migration washed away the southeastern part of the townsite prior to 1948. 
A. 1948

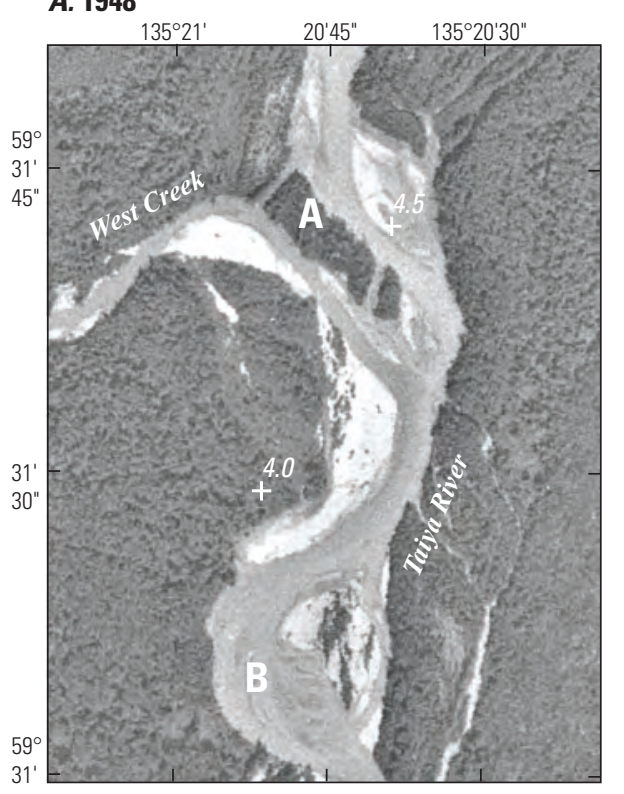

\section{2003}

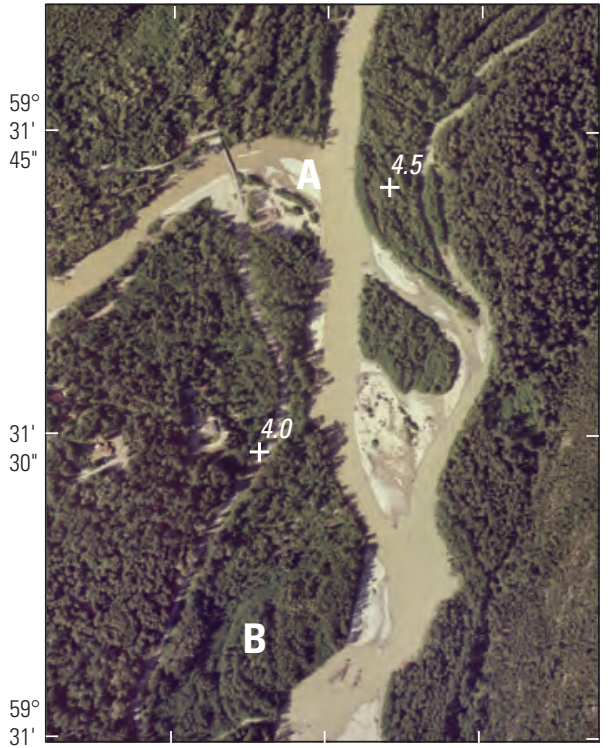

B. 1979

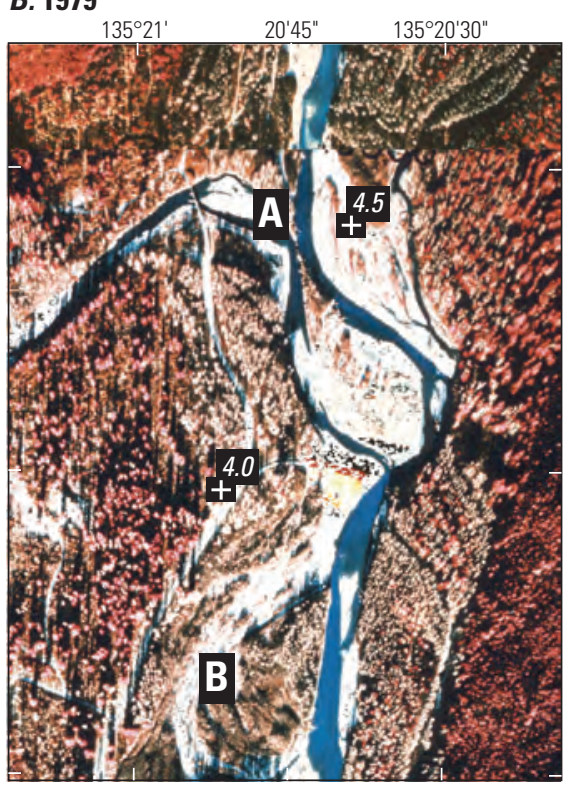

\section{E. 2014}

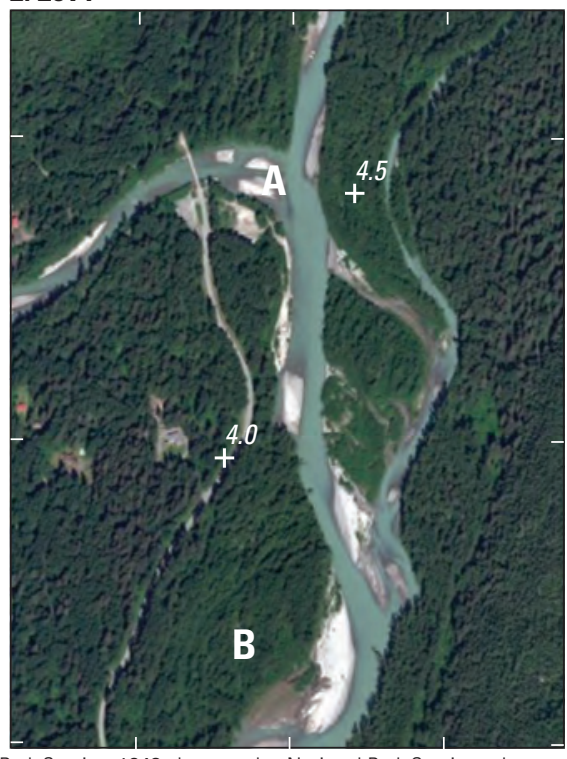

C. 1992

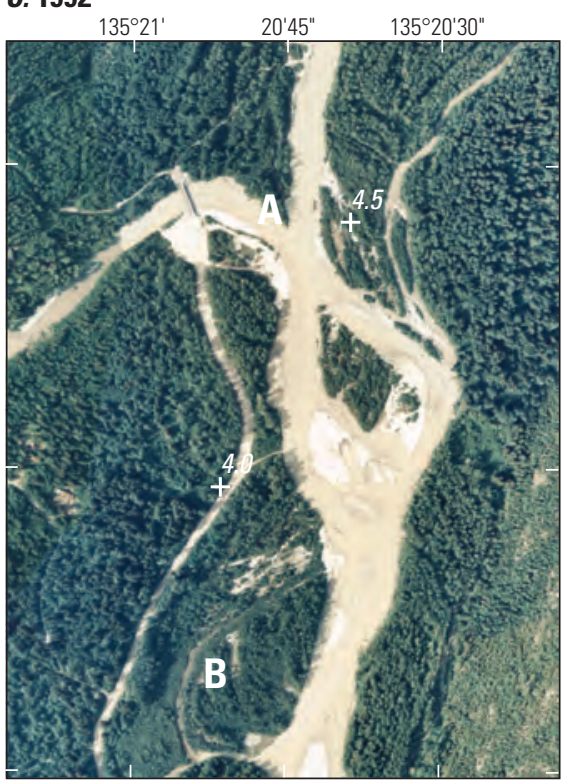

EXPLANATION

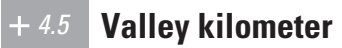

A Location of interest

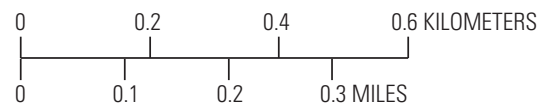

15" Imagery from USGS aerial photograph georeferenced by National Park Service, 1948 photography; National Park Service color infrared aerial photograph, 1979 photography; National Park Service orthophotograph, 2003 photography; National Park Service orthophotograph, 2010 photography; Esri World Imagery map service, 2014 photography, copyright 2018 Esri and its licensors. Universal Transverse Mercator Zone 8N, North American Datum 1983.

Figure 21. Changes to the confluence of West Creek and the Taiya River, Alaska, 1948-2014. A, 1948, black and white. $B$, 1979, color infrared. $C, 1992$, color. $D, 2003$, color. $E$, 2014, color. At the confluence, a bar separating the streams (location $A$ ) was eroded away by channel bend migration, moving the confluence location upstream and straightening the Taiya River channel. Downstream of the confluence, a bend (location B) elongated downstream then was abandoned between 1948 and 1979, reversed curvature by about 2003, and continued to erode the left bank (looking downstream) between 2003 and 2014. 
Flow in Taiya River sloughs is highly dependent on entrance conditions, which changed at some sloughs in response to channel migration, uplift, or log jams. Field observations in 2017 showed that the former entrance to Nelson Slough was perched above likely river flood stages, indicating channel response to some combination of local channel slope change from meander cutoffs and valley uplift from isostatic rebound. Near the head of the VK 4.5-7.0 slough (fig. 22), local Taiya River channel migration and formation of a $\log$ jam in the main stem between 2003 and 2010 is inferred to have reapportioned discharge between the main stem and the slough entrances (locations A and B in fig. 22) to generate an increase in slough discharge that contributed to damage to a Chilkoot Trail bridge farther downstream, near prominent beaver ponds (location $\mathrm{C}$ in fig. 22). This slough is an underfit channel in abandoned main stem flow paths and, away from the main stem-dependent entrances, has adjusted its channel location only within the confines of the former main stem banks since 1948 .

Taiya River active main stem channel change since 1948 has been largely accomplished through bank erosion. Some evidence indicates bank erosion processes are seasonally and perhaps episodically linked to high flows. Biweekly NPS bank monitoring begun in early summer 2017 noted minimal erosion until late summer or early autumn, when daily discharges were highest (Richards and others, 2017). Inglis and Pranger (2002) implicate a large flood reportedly from the 1920s and the large 1967 flood with periods of substantial erosion, but adequate evidence to verify or refute the 1920 s flood and channel change associated with these dates was not found in this study. Bank height and materials play an important role in facilitating or resisting bank erosion. Bedrock banks locally constrain the channel but the low, unconsolidated sand and gravel banks throughout most of the mapping area offer little erosion protection. Taller banks flanking the eroding meander in the Dyea area (VK 2.0) intersect the river well below the protective root zone of the overlying forest (fig. 18C), also providing little erosion protection. Accumulations of large woody debris can affect channel locations at an annual to decadal scale. Log jams have anchored bars and slough entrances within the mapping area. However, other accumulations, such as the large accumulations of large woody debris photographed by Inglis and Pranger (2002) lining the right bank in the Dyea area that were partly washed out by 2017 , have been more ephemeral.

Development since the 1940s introduced engineered channel controls. Bank protection lines much of West Creek but only selected areas of the Taiya River. At the Taiya River bridge, short stretches of riprap on both banks protect this relatively stable channel, the location of which is enforced along the upstream left bank by bedrock banks that merge with the 1952 dike across the former slough east of Dyea Road. Although the dike and bank reinforcement had lingering effects limiting channel migration potential, consolidation of flow to one channel here was likely already in progress by 1948. Riprap lines the right bank at the private property at VK 3.5 , and several discrete engineered collections of large woody debris deflect flow upstream of the property. Dyea Road is protected by riprap at an eroding bank adjacent to the southern tip of the NPS campground (fig. 18D). In the 1970s, the U.S. Army Corps of Engineers and USGS developed plans for bank protection in the Dyea area, but NPS opted for a less costly and invasive approach of relocating cultural and historical artifacts (Inglis and Pranger, 2002).

Vertical channel change assessed from 1969-2019 stage at the USGS Taiya River streamgage shows apparent incision since 1969. Historically measured stages from 1969 and the 1970s streamgaging period are elevated above the stage estimated from the most recent (2016) rating curve for a range of discharges, as are many of the measured stages from the 2002 to 2019 streamgaging period (fig. 23A). Over the period of record, the historical-recent stage differences (residuals) for the subsetted discharge measurements show a downward trend (fig. 23B), even when considering only the most recent of the two streamgaging periods. A linear regression with an adjusted coefficient of determination $\left(\mathrm{R}^{2}\right)$ of 0.88 fitted through the stage differences shows an average bed lowering of about $7 \mathrm{~mm} / \mathrm{yr}$ at the streamgage over 50 years (1969-2019; fig. 23B). Factors not addressed by this analysis include the large gap between periods of data, the apparent elevated incision indicated for the most recent few years, the location of the streamgage at a relatively laterally stable location that might be more prone to incision as an adjustment mechanism, and the lack of any abrupt changes in the longitudinal profile (fig. 16). Additional analysis to conclusively quantify incision would need to examine these issues and seek to quantify downstream horizontal migration of river base level.

\section{Sediment Sources}

The availability of sediment in an actively deglaciating basin can be qualitatively evaluated from the extent and accessibility of sediment exposed during retreat. Within the Taiya River Basin, the largest easily entrainable sediment sources consist of moraines and landslide debris in the West Creek and Nourse River valleys. Much of the sediment in these valleys is captured in lakes or stored in moraines or fans not in contact with the main stem and not accessible to the stream under 2019 conditions, but dynamic glacier, lake, and stream conditions could increase availability. Suspended sediment is fine grained and easily transported throughout the river system, such that the largest sediment sources for the turbid water in the mapping area are almost certainly the glaciers in the headwaters of the three Taiya River tributary valleys. Bedload sediment is coarser and more susceptible to deposition in lakes or within the channel where slopes and corresponding stream power decline. 


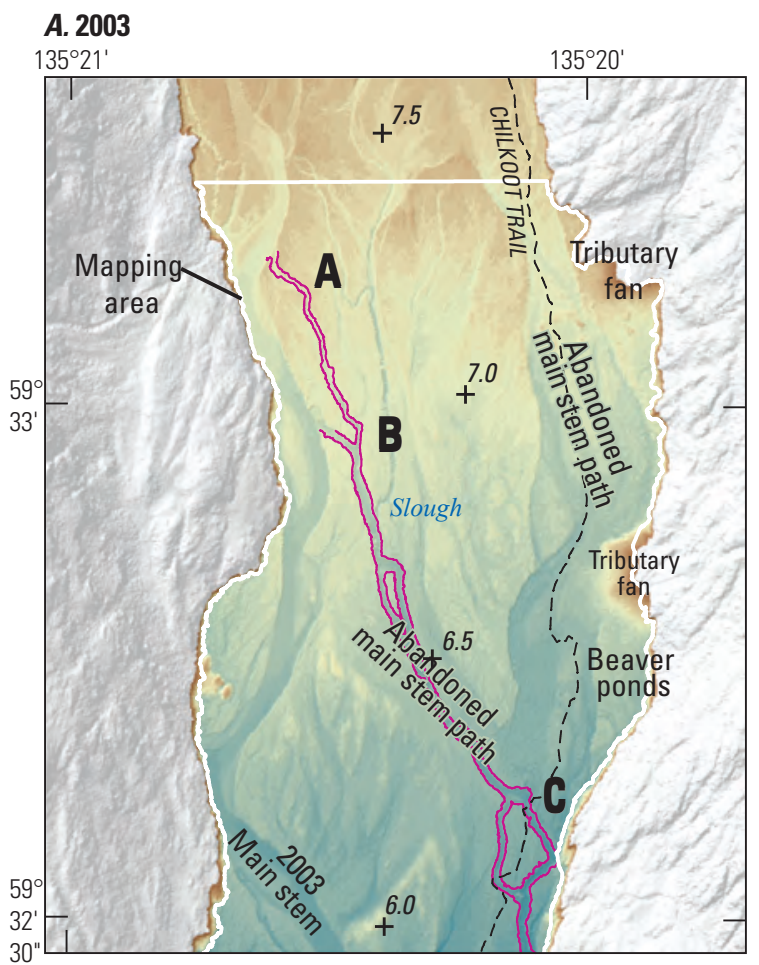

\section{B. 1948}

$135^{\circ} 21$

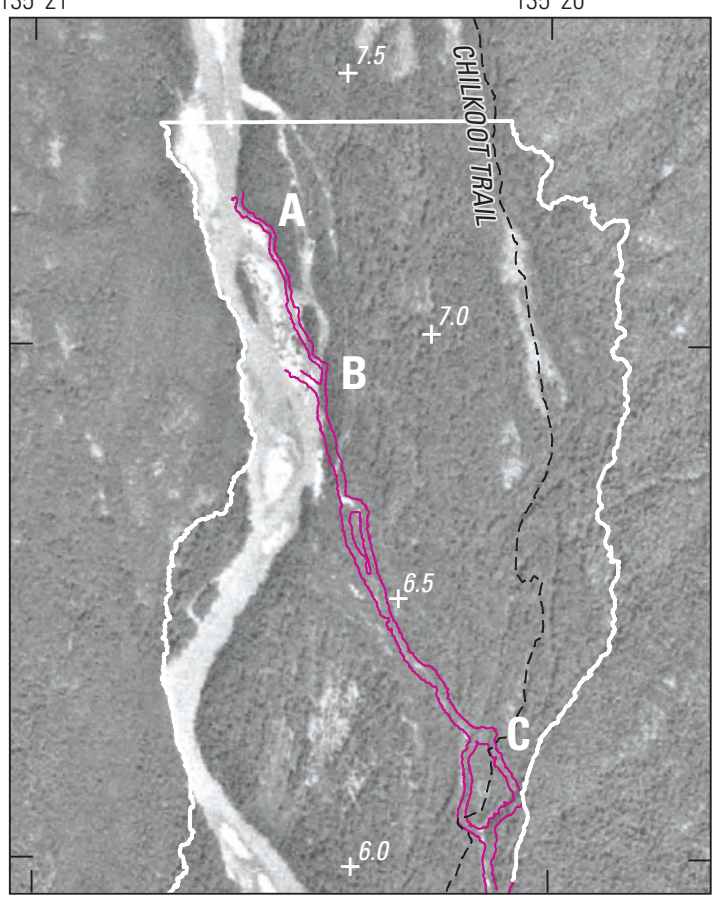

EXPLANATION

Elevation, in

meters

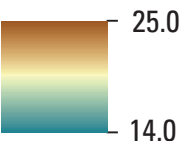

Mapping area

boundary

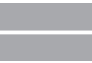

2003 slough

Valley kilometer

4.5

Location of interest

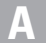

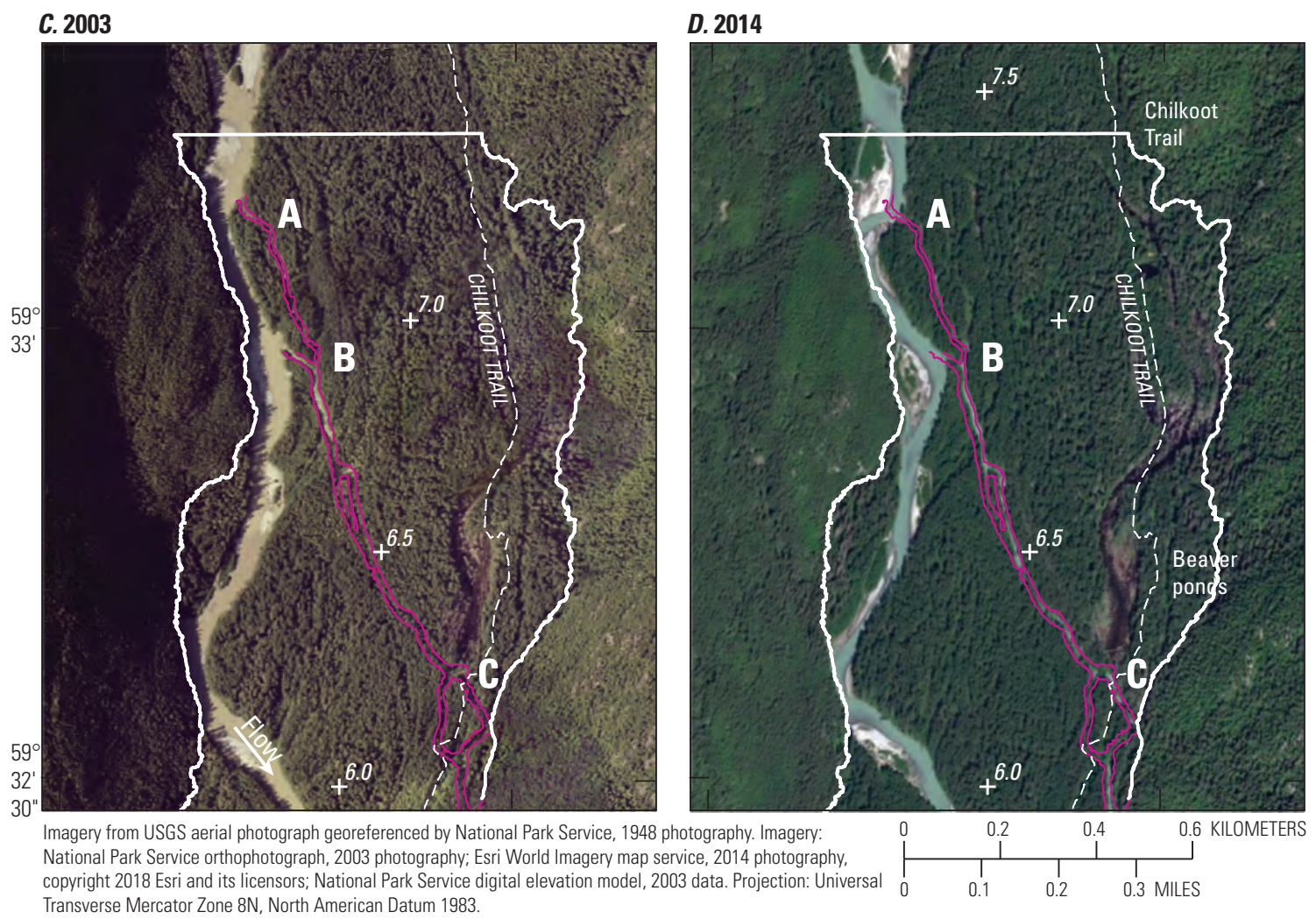

Figure 22. Changes to slough entrance conditions and constraints on slough flow path at valley kilometers (VK) 6.0-7.5, Taiya River, Alaska. A, Lidar elevation data for 2003 are shaded in 0.5-meter bands showing the upper part of the slough, which extends from VK 4.5 to 7.5 , and a tributary stream through a series of beaver ponds (see ground photo in fig. $18 \mathrm{~F}$ ) confined within the wide flow path of a suite of former main stem channels abandoned between 1894 and 1948. $B$ and $C$, The 1948 slough entrance upstream of location $A$ and the part of the slough flowing through location $B$ became inactive by 2003. $C$ and $D$, Main stem migration near locations $A$ and $B$ and creation of a log jam near location A between 2003 and 2014 (completed by 2010) likely affected the amount of flow entering the slough. Increased flow damaged abutments for a Chilkoot Trail footbridge at location C. Main stem activated between 2003 and 2018 is mapped in figure 17. 


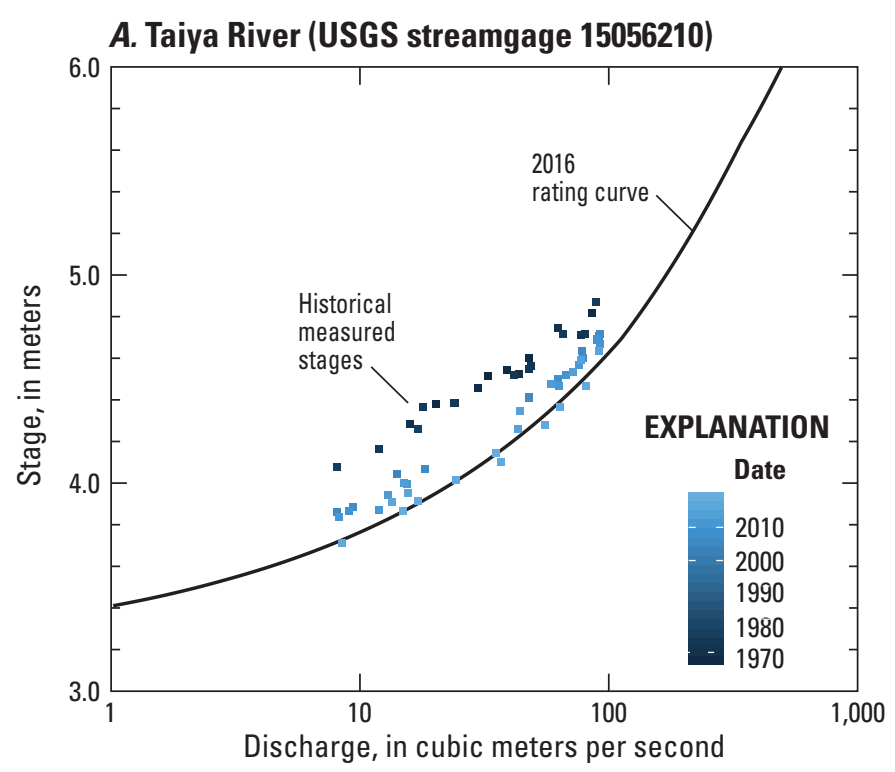

B. Taiya River (USGS streamgage 15056210)

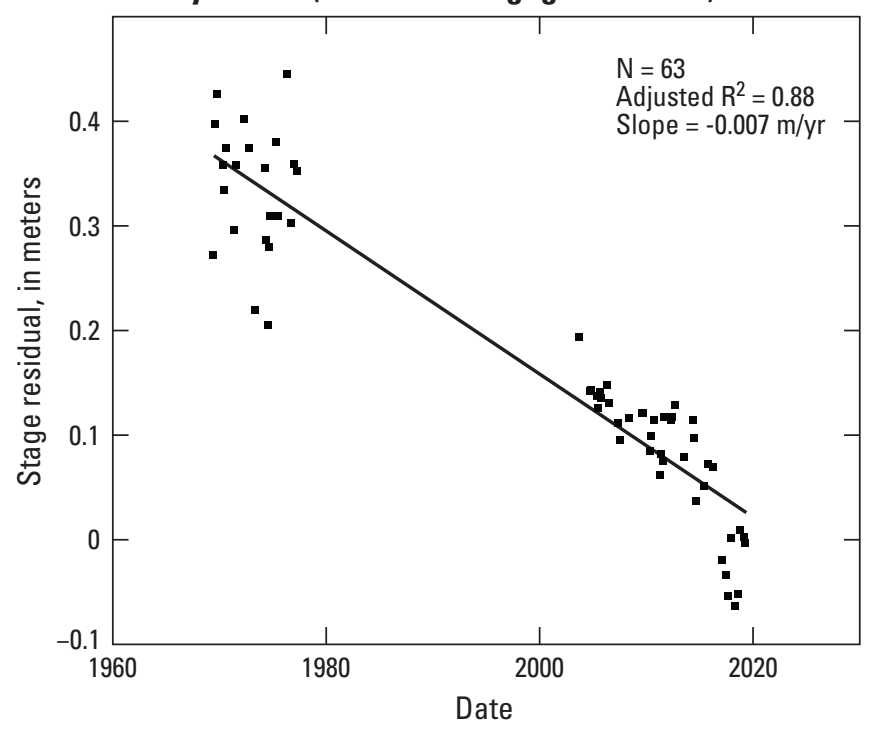

Figure 23. Incision inferred from changes in stage for a given discharge at U.S. Geological Survey streamgage at Taiya River, (15056210), Alaska. A, Selected subset of historical measured stage, by date, during 1969-2019 and the most recent rating curve, dated 2016. $B$, Regression line fitted to the differences (residuals) between the historical (measured) and recent (estimated from the rating curve) stages for a given discharge during 1969-2019. Positive differences indicate that the measured stage was higher than the stage estimated from the 2016 rating curve. [m/yr, meters per year]
In the West Creek basin, large lateral moraines from glaciers in the headwaters present a substantial sediment source that at present is largely captured in a pro-glacial lake (figs. 1 and 10A). Visible as a small feature in 1948 aerial photographs, when the glacier now contained in the eastern drainage extended into the valley bottom, this lake grew as the glacier retreated then partially filled during the 2002 lateral moraine failure and glacial lake outburst flood (fig. 10A, $B$, and $C$ ). In the western drainage, the partially failed valley bottom and large lateral moraines constitute an additional likely sediment source as the stream continues to adjust to the new slope of the failure, also at present captured in the lake. If the lake fills, sediment from the eastern and western drainages would directly enter West Creek, and the initiation of channel migration could harvest additional sediment from lateral moraines. Mass movements and tributaries along the West Creek valley walls also present a long-term sediment source. Landslide deposits adjacent to or encompassing the stream are visible in aerial photographs dating back to 1948. Alluvial fan deposits from small streams are common, supplying sediment not fully carried away by West Creek and resulting in the development of small fans that have pushed the stream away from the valley wall in some locations.

Processes associated with glacier retreat in the Nourse River valley have exposed, trapped, and episodically released sediment. Although as of the date of 2014 aerial photography, combined drainage from two large tributary glaciers directly entered the Nourse River $7 \mathrm{~km}$ upstream of the main stem Taiya River valley bottom, a pro-glacial lake immediately upstream trapped sediment from upvalley. As of 2014, two additional pro-glacial lakes in the valley bottom $14 \mathrm{~km}$ and $15 \mathrm{~km}$ from the main stem Taiya River valley bottom trapped sediment from a tributary glacier and the main valley glacier, respectively. Although the valley bottom lakes presently restrict the sediment supply from more than $13 \mathrm{~km}$ of the valley through mountainous, glacierized terrain in the upper Nourse River basin, these sediment stores could gradually or episodically be released to the stream as lakes fill or burst. The integrity of moraines trapping proglacial lakes has been investigated somewhat inconclusively (Denton and others, 2005, 2009), leaving open the possibility of a sudden pulse in sediment supply from glacial lake outburst flooding. Less catastrophic sediment harvest in the lower $7 \mathrm{~km}$ of Nourse River includes stream erosion of small tributary fans. 


\section{Off-Main-Stem Channels}

Off-main-stem channels are important contributors to the complexity of the habitat mosaic in the Taiya River valley bottom, even after abandonment by the surface-water source that formed them. Many of the channels mapped for this study are commonly referred to as off-channel habitats, or areas not subject to the full flow of a main stem channel. Because this study specifically inventoried channels present in the 2003 elevation data regardless of 2003-18 flow conditions, the term off-main-stem channel is used instead. This study identified 29 major off-main-stem channels or channel networks in the mapping area (fig. 24). Results of the channel attribute inventory are presented in table 6 in two categories: (1) channels associated with the Taiya River abandoned surfaces or small tributary fans and (2) channels associated with the West Creek fan. Photographs of selected examples of off-main-stem channels in the mapping area are shown in figure 25 . In addition to the inventoried channels, the complex of channels and beaver ponds in an abandoned main stem path near VK 6.5 (figs. 22 and 24) did not include channels readily mappable with the study methods but is considered in this discussion. An additional wetland habitat not associated with a mappable channel is present adjacent to the western valley wall at VK 2.5.

Off-main-stem channels were dominantly main stem in origin (table 6), although several were subsequently modified by tributary flow. Within the mapping area, the two largest tributaries (other than West Creek, considered a main stem channel for the purposes of this inventory) are Nelson Creek (figs. 1 and 3) and an unnamed tributary, which formed channels across their fans (channel identifiers T20 and T05, respectively; fig. 24) but flowed no more than $200 \mathrm{~m}$ across the valley bottom before emptying into larger channels of main stem origin. At several smaller tributaries, tributary flow in abandoned main stem channels (for example, channel T04, fig. 24) has resulted in a smaller channel form within an enforced flow path (an underfit stream). In other cases, such as at channel T16 (fig. 24), small tributaries have not substantially modified abandoned main stem channel forms but contribute to wetlands, ponded areas, or small flowing streams or disappear underground.

On the West Creek fan, off-main-stem channels nearly entirely consisted of small networks of channels having short-radius bends and uneven margins, unlike the smooth, long-radius bends associated with Taiya River channels, and were not associated with any obvious water sources active in 2017-18 (figs. 6D and 15). Their general radial orientation and planform dissimilarity to main stem channels indicate an origin more associated with former West Creek fan processes than main stem processes. The presence of well-established grasses and shrubs but lack of trees (fig. 25D), the interconnected nature of the channels, and the truncation of some channels by Dyea Road indicate that the channels did not form under conditions over the past several decades but could have been active within the past 100 years. Origins for these apparently relict features could include smaller fan channels, groundwater sapping, or other processes not determined as part of this reconnaissance project.

Within the inventoried channels, water was present at 62 percent of the off-main-stem channels and ranged from small ponds to flowing streams. Groundwater fed 55 percent of the channels, tributaries contributed to 27 percent of the channels, and high flow or backwater from the main stem entered 17 percent (multiple sources are possible such that these do not sum to 100 percent). Some channels (such as channel T12) had multiple sources, conveying clear water for parts of the year and receiving turbid Taiya River flow at higher discharges. For most channels near Taiya Inlet, the channel water surface equals the 2007-2011 mean higher high-tide elevation (5.1 m) at about VK2.0, which has allowed salt water to intrude into the distal reaches of Nelson Slough (channel T18) and create brackish environments observed at least as far upstream as VK 1.0 .

Beaver dams have effectively regulated hydrologic conditions in selected off-main-stem channels, creating ponds that have persisted over decades and locally altered valley bottom vegetation. Beaver activity is present upstream and downstream of West Creek but has most prominently affected two areas upstream of West Creek. At channel T04, a complex of flooded forest areas and former roads and trails fed by a tributary at VK 5.5 and dammed by beavers extended about $1 \mathrm{~km}$ along the channel as of 2018. The second area, an extensive series of beaver ponds and small streams along the Chilkoot Trail near VK 6.5 (fig. 22), was present before 2003 and extended about $600 \mathrm{~m}$ along the valley by 2018 . Standing trees killed by inundation (fig. 18F) and stressed pond-marginal vegetation indicate hydrologic conditions here are still in flux.

Clearwater side channels, considered here to be wetted channels open to the main stem at their exit but not at their head and fed by tributaries or groundwater, are identified here because of their potential importance as fish habitat. Twelve mapped off-main-stem channels met this description, of which channels T18 (fig. 25A), T12, T02 (fig. 25E), T20 and T05 were noted to be actively flowing (table 6). Several of these five channels are known anadromous fish streams and were occupied by spawning salmon during field studies (particularly Nelson Slough/Nelson Creek and channel T04). 


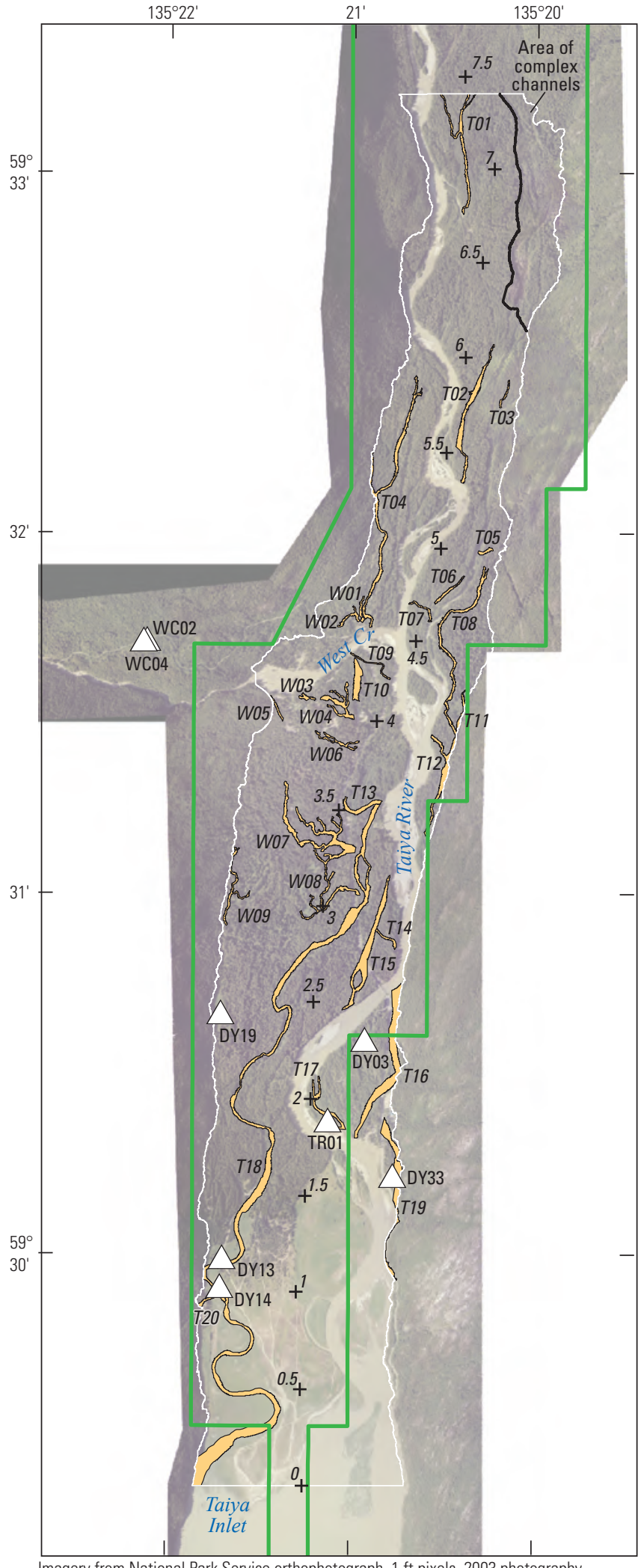

\section{EXPLANATION}

\begin{aligned} & \hline T18 Off-main-stem channel and identifier \\ & Boundary of Klondike Gold Rush National Historical Park \\ & Mapping area boundary \\ &+6.5 Valley kilometer \\ & DY13 $\triangle$ National Park Service amphibian monitoring site and identifier \end{aligned}

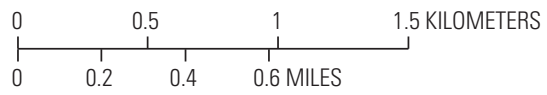

magery from National Park Service orthophotograph, 1ft pixels, 2003 photography.

Universal Transverse Mercator Zone 8N, North American Datum 1983.

Figure 24. Off-main-stem channels in the lower 7.5 kilometers of the Taiya River valley bottom, Alaska, and amphibian monitoring sites maintained by the National Park Service. 


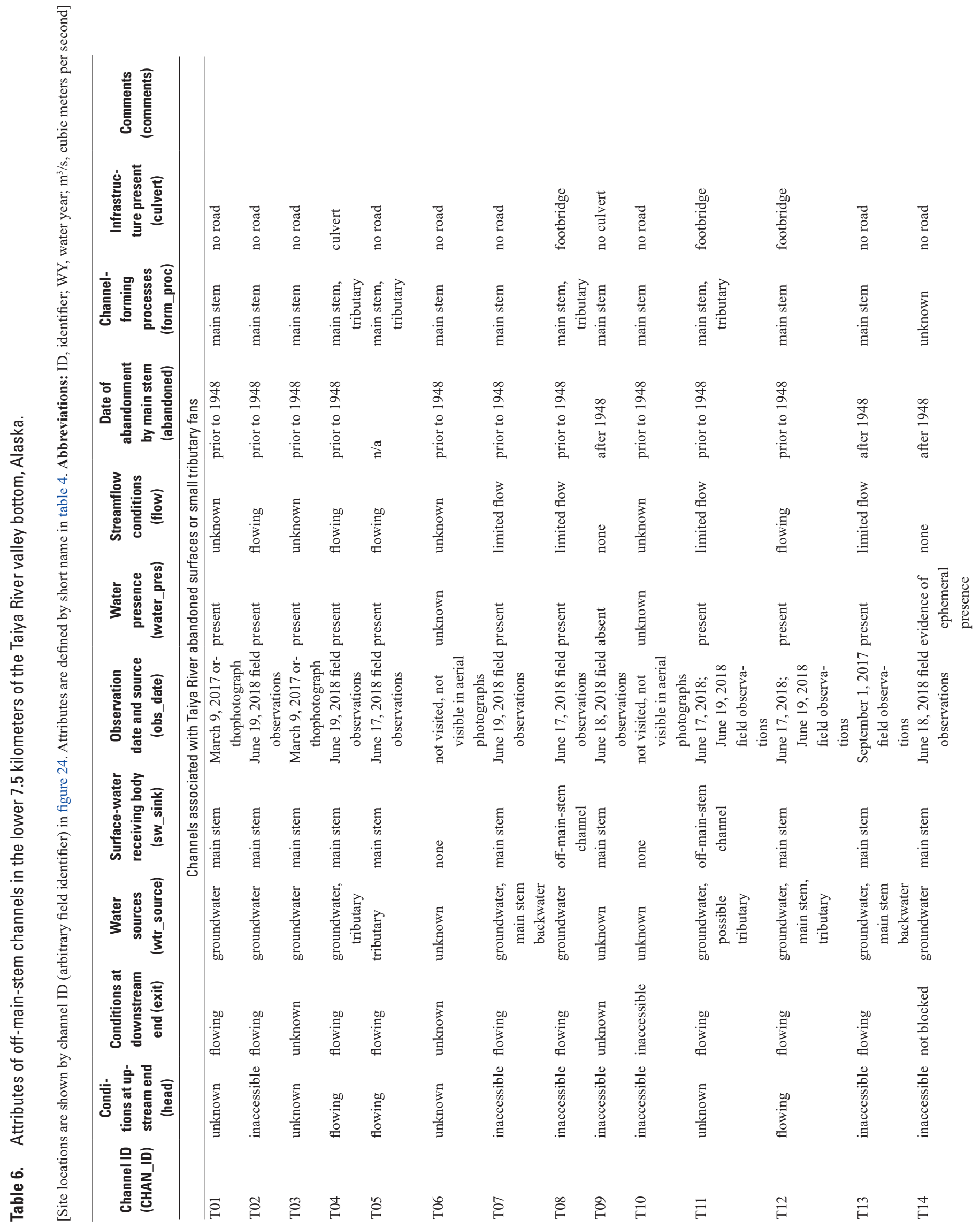




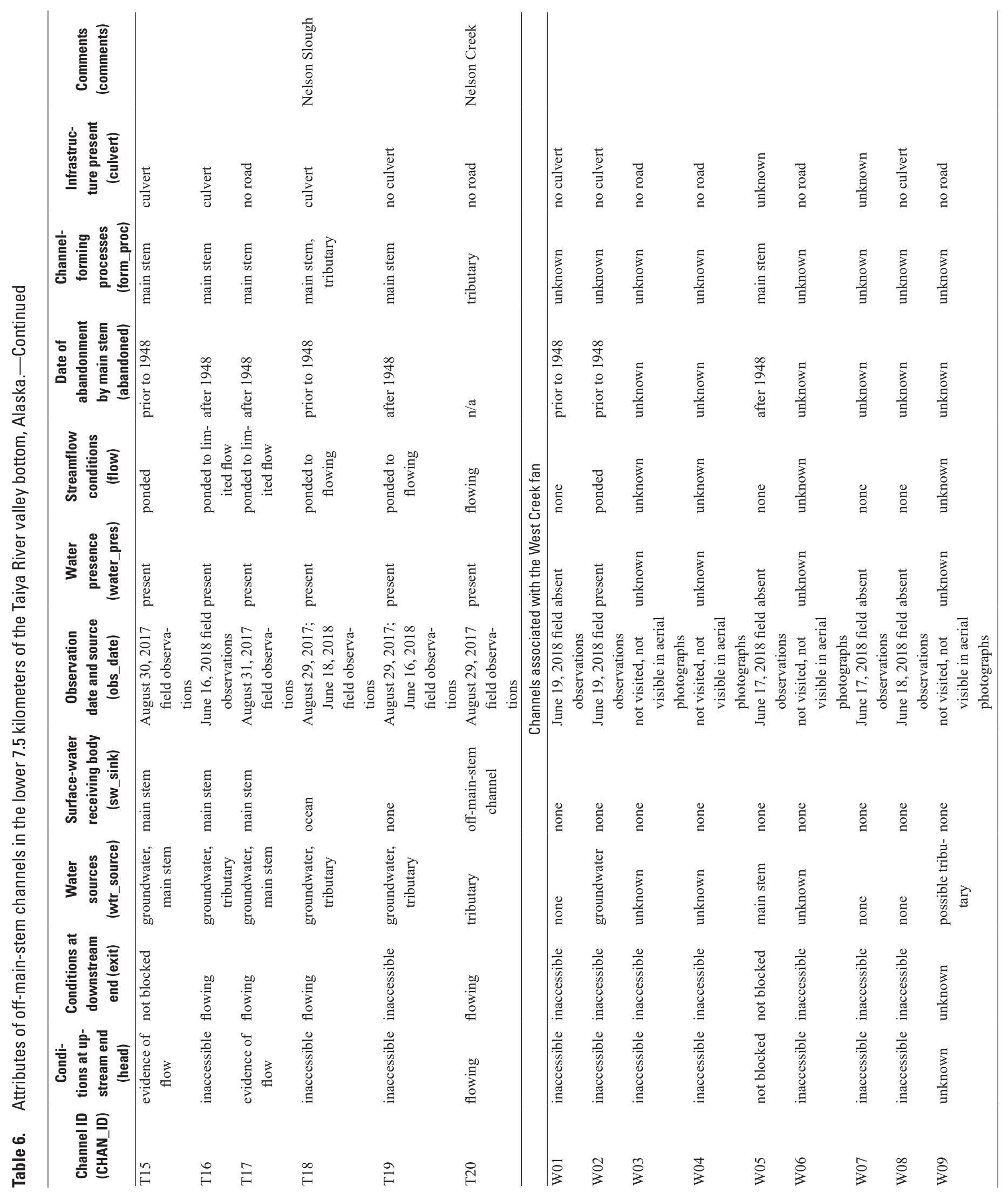


$\boldsymbol{A}$

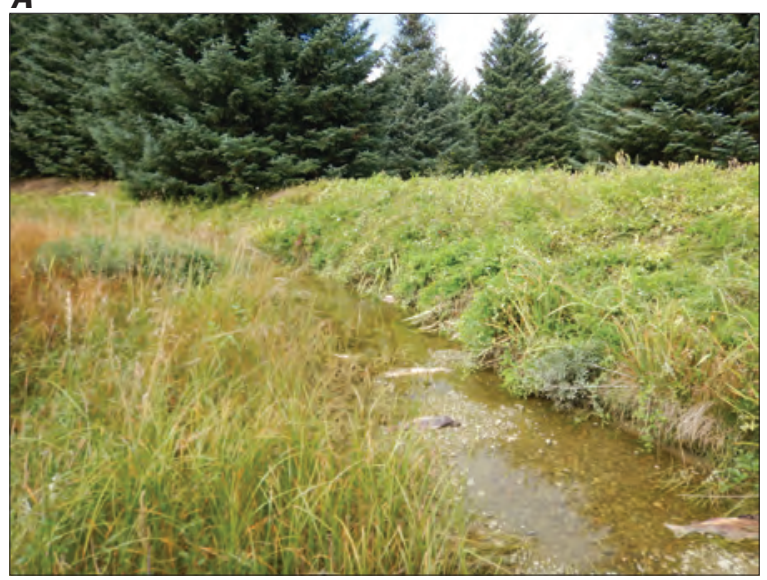

$c$

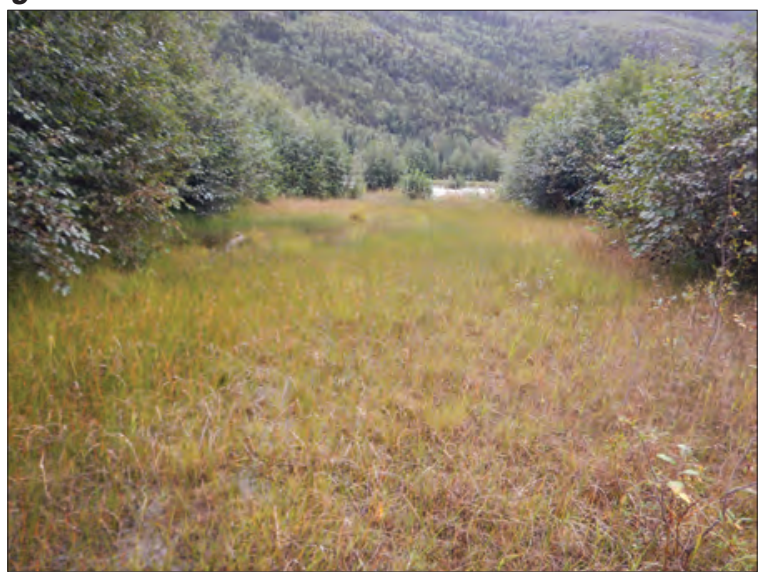

$\boldsymbol{E}$

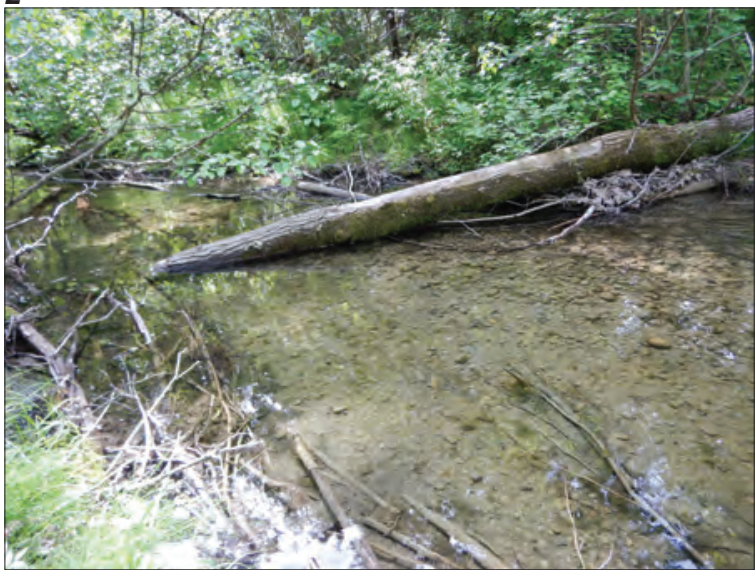

B

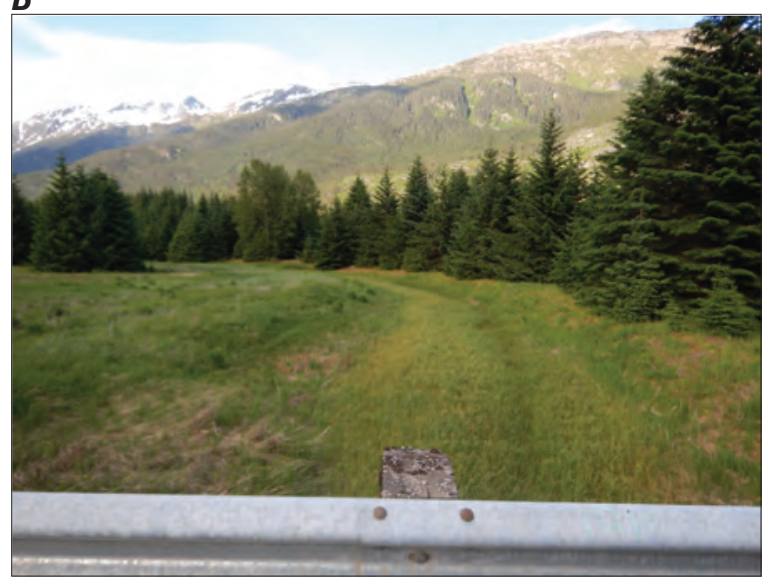

D

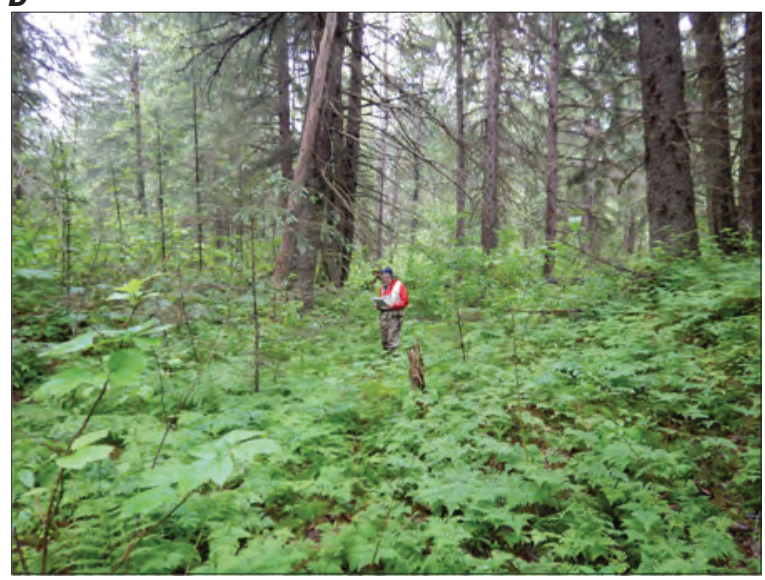

$\boldsymbol{F}$

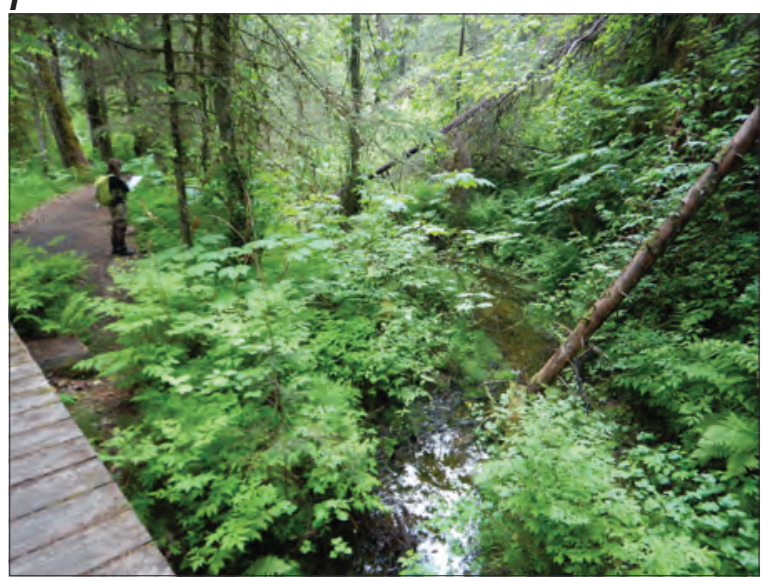

Figure 25. Photographs of examples of off-main-stem channels in the Taiya River valley bottom, Alaska. A, View upstream, post-spawning salmon carcasses in the tidally affected Nelson Slough (T18) immediately upstream of the confluence with Nelson Creek, valley kilometer (VK) 1.0, August 29, 2017. B, View downstream, wetlands in Nelson Slough (T18) at road bridge, VK 1.2, June 18, 2018. C, View downstream, shallow water in wetlands in channel T17, VK1.8, August 31, 2017. D, View upstream, author standing in center of channel W07, VK 3.3, no water present, June 17, 2018. E, View downstream, clearwater side channel in channel T02, VK 5.8, June 19, 2018. F, View upstream, Jami Belt of the National Park Service observing clearwater side channel in channel T11 upstream of Chilkoot Trail footbridge, VK 4.0, June 17, 2018. Photographs $A-C$ and $E-F$ taken by Janet H. Curran, U.S. Geological Survey; photograph $D$ taken by Jami Belt, National Park Service. 


\section{Selected Hydrogeomorphically Dependent Resources}

\section{River Recreation}

The reach of the Taiya River from a few hundred meters upstream of the West Creek confluence to the mouth of the Taiya River is road accessible and has no notable rapids. This reach is valued as a gentle float for non-motorized watercraft (fig. 18B). Abundant large woody debris in the form of relatively mobile downed trees temporarily stranded in mid-channel (fig. 26) and more persistent, partly eroded trees leaning into the river from the bank pose a riverine hazard. Hydraulics at selected river bends create challenges surmountable or avoidable by most craft at all but the highest flows. River guides suspend operation for safety reasons at a gage height of $5.2 \mathrm{~m}$, or $201 \mathrm{~m}^{3} / \mathrm{s}$. Daily discharge and annual peak discharge records, respectively, show that flows of this magnitude occur for a full day in some years but are equaled or exceeded for part of a day nearly every year. At very low flows, the river cannot float loaded rafts in selected areas such as VK 1.5-2.0, and rafters must portage over shallow reaches. Taiya River streamflow is consistently high in summer, but early spring low flows are common. Commercial rafting operators prefer to begin as soon as adequate flow is available and are thus particularly sensitive to the timing and magnitude of rising spring flows, about mid-April to mid-May.

\section{Boreal Toad Habitat}

The Anaxryus boreas boreas (boreal toad), a subspecies of the Anaxryus boreas, formerly Bufo boreas (western toad), is identified as a species of greatest conservation need in Alaska (Alaska Department of Fish and Game, 2015) and was considered for listing as endangered in other western states (U.S. Fish and Wildlife Service, 2017) owing to widespread population decline. The Alaska Wildlife Action Plan (Alaska Department of Fish and Game, 2015) categorizes the western toad as a sentinel species indicative of ecosystem health or environmental change and as culturally important. Although Alaska toad habitat preferences are less well known, toad breeding sites in other western states occupy wetland habitats ranging from open water to wet meadows, usually at elevations greater than 2,000 m (U.S. Fish and Wildlife Service, 2017). Following the first detection of a breeding site for the boreal toad within KLGO in 2002, a 2005 KLGO presence/ absence study documented breeding sites, and subsequent monitoring focused on observations at core monitoring sites where breeding had been detected (fig. 3) (Surdyk and Waldo, 2018). In 2017, the monitoring program documented evidence of breeding at 4 of the 8 core monitoring sites in KLGO, all in the West Creek or main stem Taiya River valleys (Surdyk and Waldo, 2018).

Boreal toads in KLGO (fig. 27) are known to use lowelevation wetlands as breeding sites. Six of the core KLGO monitoring sites are within the mapping area, all downstream of West Creek. An overlay of the monitoring sites with the offmain-stem channels mapped for this study (fig. 24) indicates that 5 of the 6 sites occur in channels abandoned by the main stem Taiya River since the 1940s (or slightly earlier in the case of Nelson Slough). One site, KLGO monitoring site DY19, occurs in a wetland not associated with a channel and might be fed by a small tributary entering from the valley wall. Two of the abandoned channel sites were subsequently modified by human activities, DY03 by gravel extraction activities that created ponds and DY33 by earthmoving activities associated with road construction staging and parking. Although several sites contain ponded water, and several appear to ephemerally support a small amount of streamflow, particularly at their downstream ends, none of the channels supported spatially or temporally continuous flowing water. Inundation by saltwater (in Nelson Slough) or by main stem water (at monitoring site TR01; fig. 24) episodically modifies flow conditions or water levels. Considering that the channels containing the toad breeding sites form a topographic low, and that no consistent surface-water source can be identified, shallow groundwater forms the most likely water source for the wetlands supporting the toad breeding sites.

\section{Sites Near Eroding Banks}

Many KLGO visitor amenities, including a campground and the Chilkoot Trail trailhead, and historical or archeological structures and artifacts important to NPS, such as the historic Dyea townsite, are situated near active or inactive river banks. In addition, public roadways and private properties border the Taiya River in some locations (fig. 3). The present stability of river banks is important to the security of existing features on these public and private properties, and the future stability of river banks is an important consideration in the planning process for siting future facilities, including NPS trail, road, and parking infrastructure.

Bank erosion has affected private and public properties and historical artifacts along the developed part of the Taiya River valley bottom since the early 1900s. Although channel migration rates since about the mid-1990s are small relative to those from 1948 until about the mid-1990s, bank erosion in the recent period has threatened structures and resulted in the loss of historical artifacts. Notable areas of bank erosion since the 1990s include a reach at VK 3.5 (fig. 17) and the sweeping meander bend near the Dyea townsite/NPS campground at VK 2.0 (figs.17 and 20). 


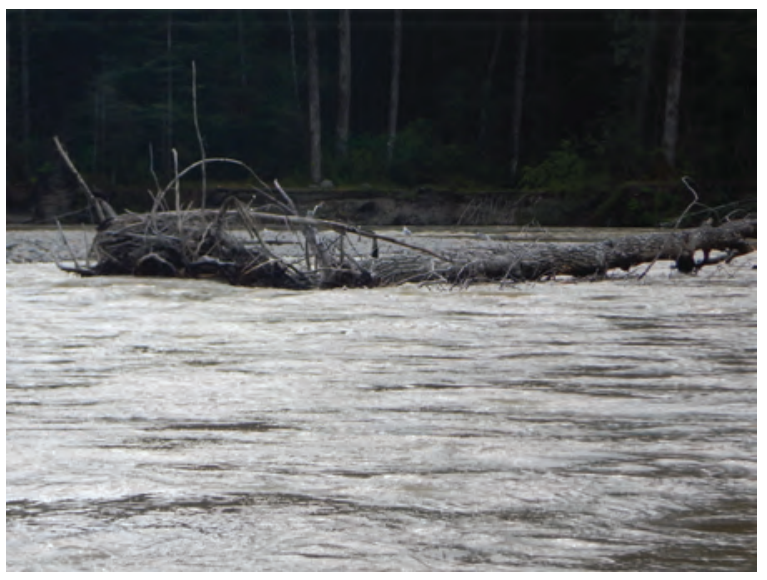

Figure 26. Large woody debris in mid-channel, Taiya River, Alaska. Photograph taken by Janet Curran, U.S. Geological Survey, August 30, 2017.

$\boldsymbol{A}$

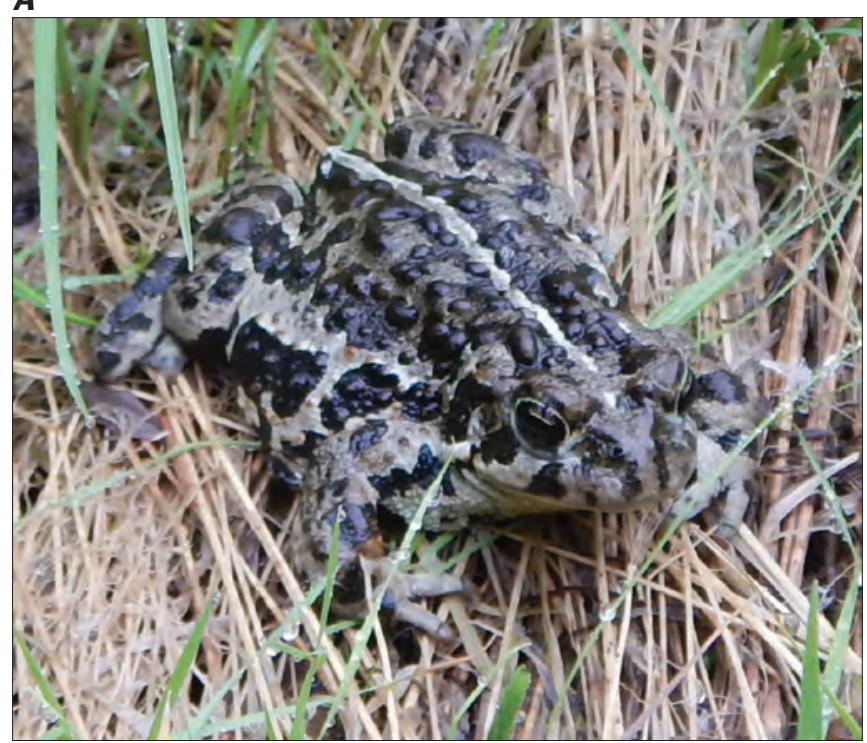

B

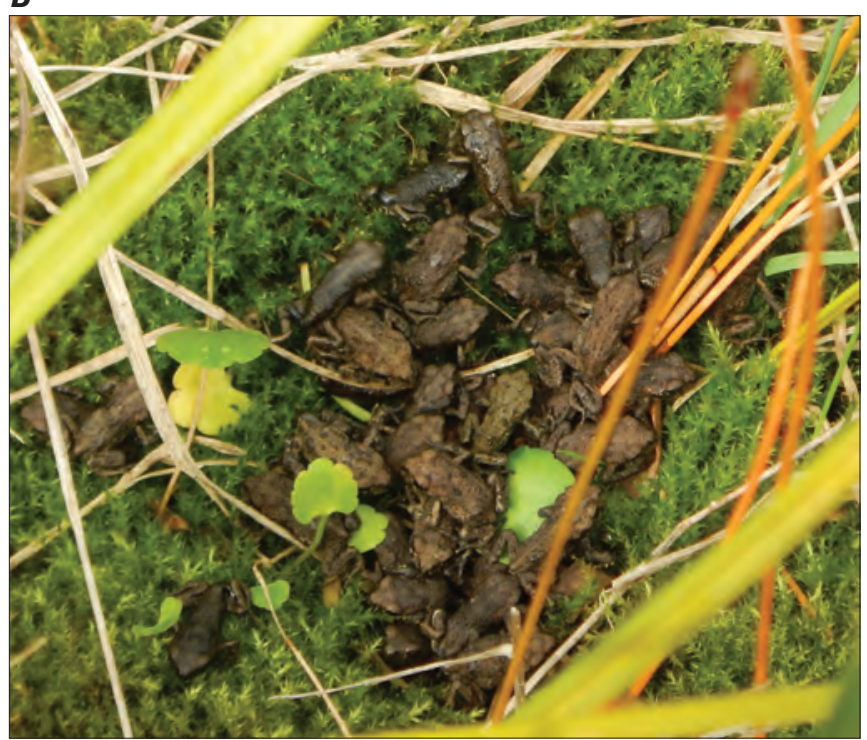

Figure 27. $A$, A boreal toad adult and, $B$, Metamorphs in wetlands formed in abandoned sloughs of the Taiya River, Alaska. Photographs by Janet Curran, U.S. Geological Survey, A, June 16, 2018, and B, August 29, 2017. 
At VK 3.5 (fig. 3 and just south of the area shown in fig. 21 ), channel change in the 1990s eroded the right bank (as viewed by an observer looking downstream) along the only developed bankside private property on the river and motivated the placement of riprap to protect the bank and large woody debris to redirect streamflow by the 2000s. Channel change at this location has involved complex reworking since at least 1948 that is likely associated with the natural reconfiguration of the West Creek confluence. Several episodes of meander migration immediately upstream (fig. 21, location B) resulted in reverse curvature of the 1948 meander and development of a new meander with an apex at VK 3.5. Erosion during 2017-18 continued to affect the left bank, as detected as by NPS monitoring (Richards and others, 2017) and seen in aerial imagery (table 2), and unprotected areas near the private property on the right bank.

River bank erosion associated with meander migration near the Dyea townsite (fig. 20) has drawn repeated attention for its incursion on this historic area, which originally contained many Gold Rush artifacts and at least two historical cemeteries. As of 2018, more than one-half of the townsite had been eroded away, including the recent loss of nearly all of the cemeteries. Two distinct areas of channel change can be identified at this site. At the downstream end of the historical Dyea townsite footprint, scalloped channel scars in the 1948 aerial photograph (fig. 20) record channel migration prior to 1948 that resulted in loss of the southeastern quadrant of the townsite and subsequent abandonment of the area, now part of a low terrace (mapped as abandoned channel in fig. 17). A second area consisting of the existing meander centered at about VK 2.0 and extending from VK 1.7-2.6 has eroded episodically since about the $1920 \mathrm{~s}$. The ongoing progression of this meander from part of a relatively straight suite of channels along the eastern side of the valley in 1917 to a pronounced meander bend can be seen in ground and aerial photographs and historical property survey maps and has been detailed by annual NPS monitoring since 1979 except for a brief period in the 1980s (Inglis and Pranger, 2002; Richards and others, 2017). A maximum of $150 \mathrm{~m}$ of erosion occurred between 1918 and 1948, followed by a roughly equivalent amount of erosion between 1948 and 2018. The current right bankline (looking downstream) is the cumulative product of lateral migration of an upstream meander active between 1948 and 1970 and a partly overlapping, slightly downstream meander active between 1970 and 1979, followed by downstream migration of the combined meander between 1979 and 1992. Between 1992 and 2016, erosion was minor to negligible. In May 2017, monitoring detected a new episode of erosion, and during 2017 as much as $14 \mathrm{~m}$ of erosion widened the curve near the apex of the meander (Richards and others, 2017). This brought the maximum lateral erosion between 2003 and 2018 to $19 \mathrm{~m}$ (seen as the recently added main stem area in fig. 17). Along the inside of the meander bend, former channel areas progressively became a point bar, which in 2019 supported NPS facilities, including a campground, and erosion has affected the campground and Dyea Road (fig. 18D).

\section{Hydrogeomorphic Implications for Taiya River Resources}

The geologic and fluvial history of a river valley provides a basis for anticipating future river conditions consistent with the context of natural processes in the basin. For the Taiya River, it is important to consider how natural processesfaulting, glacier retreat, isostatic rebound, flooding, changes in water and sediment supply - have conditioned the valley bottom and how dynamic those processes are. The general configuration of the main stem valley has been set by the geologic-scale processes of faulting and the long-term erosive and depositional power of glaciers and streams. The geomorphic history of the valley can be considered to have established the framework for channel position and planform, and the present streamflow and sediment regimes, together with large woody debris and beaver activity, can be considered responsible for maintaining or modifying the stream channel morphology and availability of water for aquatic habitats and wetlands in the future.

\section{Evolution of Valley Bottom Surfaces and Channels}

Informed management and conservation of the KLGO resources considered in this study rely on understanding the primary hydrogeomorphic controls on channel form, channel position, and channel formation. The Taiya River consolidated its channel from multiple major paths in 1894 to a single major path by 1948. Since 1948, the river has narrowed its suite of active channels and bars within this flow path. Unlike the frequent reworking of braided channels in many glacial streams, the general path of the mostly single-thread Taiya River has not changed appreciably since 1948 . The notable narrowing and stabilizing of the Taiya River from a multithread, braided planform to a mostly single-thread planform could not be readily attributed to one factor for this reconnaissance study. The river changes since prior to the Gold Rush that are recorded in abandoned channels (fig. 14) and in aerial photography occur concurrently with dynamic changes in glacier contributions to streamflow and sediment, including known and likely glacial lake outburst floods that could have temporarily widened the unvegetated corridor, particularly if recurring, but also including the loss of direct sediment contributions by the formation of proglacial lakes. Regardless of cause, the importance of an apparent progressive change in the width of the active main stem is that, at the valley scale, it indicates some permanence to the current general flow path and a reduction in the capacity of the stream to readily rework the entire valley bottom. At the multi-kilometer scale within the mapping area, the general location of the Taiya River is presently relatively laterally stable and could remain relatively stable at this scale unless future flow and sediment regimes change. 
Within the mapping area, notable channel change occurred at small spatial and temporal scales, on the order of decades over reaches on the order of $1 \mathrm{~km}$ long. From the West Creek confluence to about $1 \mathrm{~km}$ downstream, the West Creek and Taiya River channels have changed in a complex manner since 1894 (figs. 21 and 24). Continued minor change between 2003 and 2018 indicates that bank erosion and channel change will continue at this location until a more stable configuration is reached. Downstream of the Taiya River bridge, the branching river of the Gold Rush era consolidated into a single strongly meandering channel along the eastern side of the valley by 1948, a change not unlike the reduction of flow paths upstream of West Creek. Complex meander migration since the late 1800 s that cumulatively eroded one-half of the former Dyea townsite occurred episodically, such that periods of relative stability (on the order of decades) were interspersed with relatively swift channel migration (on the order of single to multiple years). The assertion by Inglis and Pranger (2002) that "the river will eventually migrate through and destroy the remaining portions of Dyea if the channel bank is not stabilized" seems an accurate reflection on a river having an abundant supply of water and sediment in an easily erodible, fluvially reworked valley bottom, although the timing of this eventuality is unknown. The size of the present single large meander bend at VK 2.0 (figs. 2 and 20), technically a composite of several former smaller bends, is unprecedented within the mapping area. Short-term erosion of the outer bank of this bend, on the scale of that seen in 2017 or even the larger amounts of several decades ago, is likely to continue until more substantial and complex channel changes reduce meander curvature and rework flow paths.

Influences on Taiya River position and channel migration since 1894 include flooding, uplift, West Creek processes and deposits, and locally, large woody debris. Large floods, whether meteorologic or outburst, have the potential to reset vegetation cycles, alter aquatic habitat characteristics, erode banks, rework channel locations, and flush or deposit sediment. The effect of flooding prior to 1948 is difficult to ascertain but was suggested by Inglis and Pranger (2002) to have initiated bank erosion in the Dyea area. The largest flood in the Taiya River since 1948, a 1967 rainfall-generated flood, damaged infrastructure (Boning, 1972), but the extent of major channel change that can be attributed to the flood is unknown. The 2002 West Creek glacial lake outburst flood appears to have widened the active stream corridor in West Creek and flooded, but not substantially altered, the West Creek fan and the Taiya River. However, bank erosion noted during 2017-18 occurred in the absence of large floods. Although large floods have affected Taiya River channels, change has not been exclusively associated with large floods, indicating that the range of flows in the past several decades are capable of modifying channel planform despite apparent reductions in channel size since 1894. Flooding also can form or mobilize collections of large woody debris, or log jams. Log jams present at the entrances to many back-bar channels and sloughs often regulate flow to these small channels, and buried relict log jams may locally control channel migration (Inglis and Pranger, 2002). Large woody debris was common as of 2018 and includes entire mature trees, indicating that channel migration is capable of harvesting trees from relatively stable surfaces.

Land-surface uplift from isostatic rebound, when coupled with river incision, can create fluvial terraces and disrupt hydrologic connectivity of sloughs, off-main-stem channels, and groundwater systems supporting off-main-stem wetlands and channels. KLGO has recognized the potential for wetland drying associated with isostatic rebound (Bernatz and others, 2011). Terraces consist of former fluvial surfaces elevated above the stream that can no longer be accessed by the stream, even at flood levels. Within the mapping area, terraces are most prominent along the right bank downstream of the West Creek fan, where bank heights commonly exceed $1 \mathrm{~m}$ (figs. 3 and 14). The currently perched head of Nelson Slough could be attributed to an uplift/incision response or to a bed elevation change from the complex channel changes there. Analysis of historical stages at the Taiya River streamgage shows an average of $7 \mathrm{~mm} / \mathrm{yr}$ of incision there since the 1960s (fig. 23). Compared to uplift rates of $16 \mathrm{~mm} / \mathrm{yr}$, the $7-\mathrm{mm} / \mathrm{yr}$ incision indicates that uplift might be partly accommodated by stream incision and partly by downstream extension of base level as uplifted estuarine deltaic deposits become fluvial and that neither process dominates the fluvial response. Bedload transport in the Taiya River has been sufficient, at least in the past, to construct an extended gently sloping delta visible at low tide; as the delta is uplifted, the river becomes longer unless incision counteracts this effect. The Taiya River longitudinal profile was not critically examined for this study but the lack of obvious abrupt changes at the scale plotted in figure 16 indicates no substantial knickpoints have been generated by river adjustment to base-level change.

As a major tributary to the Taiya River, West Creek exerts a geomorphic effect on the Taiya River by substantially increasing the active width and sediment transport capacity of the river. Major main stem planform changes since 1948 within the mapping area have all occurred downstream of West Creek, where additional streamflow from West Creek and from a major slough increases stream power. The historical West Creek fan contributes significantly to the downstream change in width of the historical Taiya River flood plain in the mapping area, which is a braid plain occupying the whole valley bottom from about $0.5 \mathrm{~km}$ upstream of West Creek and is a meander belt confined to about half the valley by the West Creek fan and fluvial or uplifted tidal terraces downstream (figs. 14 and 15).

The West Creek fan is inferred to have contributed to the century-scale persistence of the Taiya River location along the eastern side of the valley. The West Creek fan has deflected the Taiya River since at least 1894 (fig. 19A) and possibly longer despite the relatively inactive fan processes indicated by its surface features. The mostly non-wetted networks of small, short-radius channels clustered around the distal margins of the West Creek fan pre-date roads and cleared developments, 
providing a minimum age for changes to hydrologic processes on the West Creek fan. The interplay between West Creek fan construction and Taiya River fan trimming does not appear to be a geomorphically prominent process at the mouth of West Creek at the annual to decadal scale. Interactions at the West Creek confluence since 1948 instead appear more associated with channel migration. This indicates that the volume of bedload sediment from West Creek has been at least historically adequate to have affected the position of the Taiya River within the valley, but the sediment has not overwhelmed the transport capacity of the Taiya River since at least 1948. Taiya River channels are likely still sensitive to changes in the West Creek confluence angle, which is presently partly constrained by bank reinforcement.

Tributary fans often develop from deposition of coarse sediment at the slope transition between valleys because coarse sediment can no longer be carried by the lower-gradient stream, but the relative sediment size of the West Creek fan could not be determined from this study because of vegetation and lack of exposures except for sediment in the active stream. Bedload sediment presently transported across the West Creek fan does not appear substantially different from bedload sediment transported in the Taiya River. Sediment in bars at the mouth of West Creek is similar in size to sediment in Taiya River bars just upstream of West Creek. Boulders near the fan head indicate local coarseness, which could facilitate stream losses to groundwater.

In addition to the relative stability of the Taiya River stream corridor, channels within the corridor also shift infrequently. Unlike many glacier-fed streams in Alaska, where multiple channels interweave frequently across a broad gravelly plain, streams in the Taiya River Basin do not contain substantially braided reaches. This has implications for the disturbance regime of the river, which is stable relative to a braided river. Channel change since 1948 has occurred as slow, progressive change at most locations alternating with rapid, episodic change at selected meanders and infrequent, rapid complex channel avulsions in other locations.

\section{Streamflow and Sediment Timing and Seasonality}

KLGO resources dependent on the delivery of streamflow include river recreation and habitats for not only boreal toads but also important biological resources such as anadromous fish. The present effect of West Creek on the magnitude and timing of Taiya River discharge is also important as a basis for evaluating future proposals for West Creek water-resources management. The similarity of West Creek and Taiya River seasonal (fig. 9) and daily discharge patterns reflects similarity in basin characteristics and streamflow generating mechanisms between the streams. Notably, the West Creek basin contributes considerably to Taiya River discharge magnitude but produces only small variations in the timing of delivery of water, mostly as a slight shift toward more discharge in winter relative to the mean annual discharge (fig. 9). Thus, any future management of West Creek flow that reduces discharge magnitude but not timing would not necessarily alter the timing of Taiya River discharge. The decadal-scale shift toward an earlier spring rise in discharge seen between the two periods of gaging at the Taiya River streamgage (table 5, fig. 8) likely relates to an increase in spring temperatures, given the strong response of Taiya River discharge during April-June to temperature demonstrated for a short period of data available for the Taiya River streamgage (fig. 28). Drivers of change in spring temperatures can be the result of many factors beyond the scope of this study, including long-term trends in climate and decadal-scale oscillations such as the Pacific Decadal Oscillation.

Suspended sediment concentrations are an important consideration should future West Creek management include damming the stream and are presently relevant to considerations for riverine and seasonally inundated habitats. West Creek and Taiya River suspended sediment concentrations over the collective previous period of record (1963-2004) and the study period (2017-18) fell within the range of values measured in glacial streams, reaching the highest values in about June through September, concurrent with the peak of the summer high-flow season. Factors that could affect suspended sediment concentrations include possible moderating effects of small lakes in the Nourse River and West Creek valleys and temporary increases in suspended sediment supply from landslides in West Creek, although neither process was investigated for this study. The suspended sediment concentrations in West Creek and the Taiya River vary considerably with season and from year to year. As discrete samples, these measurements are more suited to seasonal characterization and miss other expected patterns, including diurnal variations, pulses, or variations between the rising and falling limbs of storm discharges. The turbidity measurements collected by SEAN (Sergeant and Johnson, 2018) provide additional temporal detail consistent with glacial streams, but additional calibration would be required to link the turbidity and suspended sediment data for quantitative assessment of continuous rather than discrete suspended sediment loads.

\section{Wetland Water Sources}

Wetlands, including off-main-stem channels, and sloughs are scarce in the mapping area but provide high-value habitat for species such as the boreal toad. In part because of this scarcity, understanding the processes that form wetlands and maintain their water levels is important. Estuarine wetlands are likely to remain at the interface between the Taiya River and Taiya Inlet, although their location will continue to migrate downvalley as land surface rises. Extensive, channelized flats exposed at low tide indicate that deltaic sediments extend offshore to support generation of new land with uplift. Off-main-stem wetlands in the mapping area are generally contained in former stream channels. Although new channels 


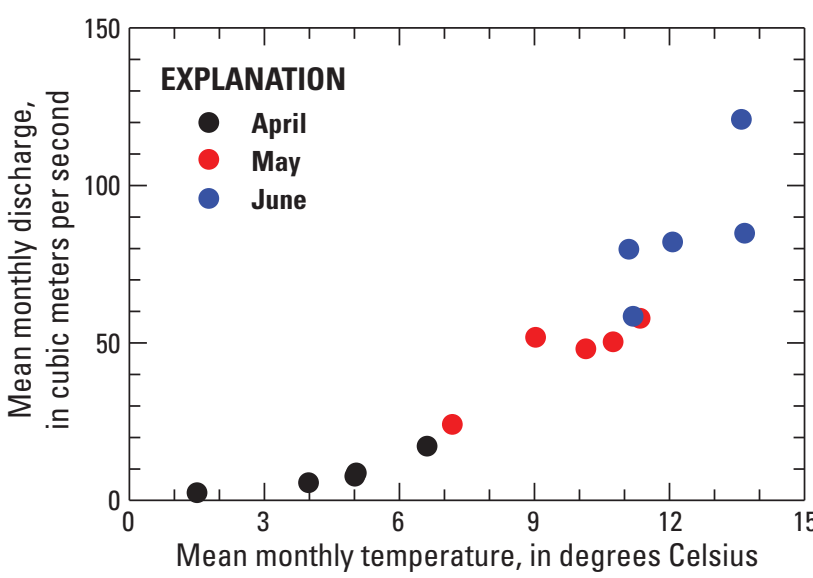

Figure 28. Mean monthly discharge during April, May, and June, 2012-16, in relation to mean monthly temperature for the Taiya River at U.S. Geological Survey streamgage 15056210, Alaska. Temperature data for the Taiya River are from the Western Regional Climate Center at https://raws.dri.edu/cgi-bin/rawMAIN. pl?akATAI.

can be created in association with main stem channel changes, the present relative stability of the Taiya River indicates that rates of new off-main-stem channel creation are low. Relic channels on the West Creek fan may presently provide wetland habitat but appear unlikely to support flow under present 2017-18 conditions. A wetland along the western valley wall at about VK 2.5 was the only wetland not clearly associated with a channel. Identification of wetland water sources is important for assessing the stability of wetlands in the face of local channel change, climate variability, and the unresolved potential for uplift to disconnecting wetlands from riverine flooding and groundwater sources.

Water sources observed or inferred for wetlands include small tributaries, which flow across abandoned fluvial surfaces before joining the main stem Taiya River or West Creek, seasonal or flood-related inundation by main stem flow, tidal effects, and groundwater discharge. By number of channels affected, the inventory of off-main-stem channels indicates that groundwater forms the primary water source for off-mainstem channels, followed by tributaries and then main stem flooding. The interpretation of flow in abandoned channels without an obvious surface-water source as groundwater-fed is supported by interpretations from Paustian and others (1994), who surmise that shallow flood-plain aquifers sustained flow in some abandoned main stem channels. The inventory of channels and water sources presented here serves to identify existing features but is a snapshot in time and can be expected to change as main stem channels move or water sources change.
In addition to precipitation and losses from the Taiya River, West Creek is a candidate for contributions to shallow valley groundwater recharge because of the steep nature of its entry to the valley and the potential coarseness of its fan deposits. Although flow losses from West Creek cannot be quantified with the available data, no gross discrepancies between West Creek and Taiya River streamflow or obvious springs were observed to indicate that West Creek is a strongly losing stream. Off-main-stem wetlands are present upstream and downstream of West Creek, also indicating no overt dominance of West Creek over groundwater recharge.

\section{Monitoring Considerations}

Existing monitoring efforts relevant to hydrologically or geomorphically dependent resources already underway at KLGO include monitoring of boreal toad breeding sites, which provides descriptive hydrologic observations such as pond drying and overtopping by main stem flow. KLGO also monitors bank erosion at selected locations. USGS monitors streamflow at the Taiya River streamgage, and SEAN monitors selected water-quality characteristics, including turbidity, at the streamgage.

Approaches to monitoring that further an understanding of the groundwater system that likely is the primary water source for many clearwater side channels and wetlands, including toad breeding sites, would facilitate the evaluation of the hydrologic effects of West Creek and the Taiya River on wetland habitats. This and other studies have attributed the presence of water in many small, non-tributary clearwater channels and other wetlands to groundwater (Paustian and others, 1994), but an understanding of the source of groundwater recharge would be required for evaluating future hydrologic conditions in these features. Because wetlands are not abundant in the Taiya River valley bottom and slowed lateral migration of the Taiya main stem indicates fewer off-main-stem channels are being created, wetlands have the potential to become individually important, such that localized processes might be relevant as well as valley-scale processes. Monitoring groundwater levels in wells or piezometers would more formally document conditions. The extent of seasonal and annual variations in groundwater levels would provide a basis for evaluating the relative effects of more regional groundwater sources and local aquifers that likely fluctuate in association with river levels. The spatial distribution of water-level monitoring could be designed to provide information on the influence of West Creek on the Taiya River valley bottom groundwater system. Other methods for determination of losses to groundwater include concurrent measurement of discharge upstream and downstream of potential loss points, such as on West Creek near the valley margin. Techniques for identification of water sources, such as isotopic fingerprinting, might also facilitate assessment of the relative contribution of West Creek. 
Although the response of the Taiya River to rapid uplift is offset to some degree by lengthening of the stream downstream as estuarine, deltaic surfaces are uplifted, emergence of new land at the tidal interface and any incision that disconnects aquatic-terrestrial processes likely would also affect vegetation. Colonization of new land and shifts from water tolerant to water intolerant species can be a marker for hydrologic change. High-resolution imagery (aerial photographs or satellite imagery) analysis can assist with detection of vegetation changes, as can repeat field observations at plots. Detection of the river response to incision could include monitoring channel change at long-term fixed locations, such as the Taiya River bridge. Repeat longitudinal surveys of water-surface elevations, preferably at low flows or at a consistent flow, could provide a more spatially distributed measure of longterm elevation change.

The existing bank erosion monitoring program captured most of the major changes to banks downstream of West Creek since at least 2003, but this can be considered a period of relative stability in that most bank erosion consisted of progressive meander migration rather than complex reworking of channels. Periodic analysis of high-resolution imagery could complement this program by capturing changes at banks not regularly monitored and would assist with detection of complex channel changes. If major changes occur, new lidar acquisition can be an effective means to delineate eroded banks over a larger area and quantify analysis of changes in elevation.

Although this study provided a preliminary framework of the relative age structure of the valley bottom fluvial surfaces and coarse categories of formative processes for those surfaces, chronological dating (such as tree ring analysis or isotopic methods), stratigraphic assessment of deposits, and more detailed evaluation of the surface expression of fluvial deposits could help refine the understanding of the relative role of glacial lake outburst floods, the stability of the West Creek fan, and other geomorphic issues. A thorough investigation of aerial and ground imagery could also help determine the effects of major floods from outside the mapping area. A more formal measurement of bed-particle size than was possible for this study would be needed to conduct hydraulic analysis for engineering or environmental purposes or in support of analysis of river incision/deposition.

\section{Summary and Conclusions}

The Taiya River drains a 481 square-kilometer $\left(\mathrm{km}^{2}\right)$ basin from glacierized mountains to Taiya Inlet at the head of Lynn Canal, a long fjord in southeastern Alaska. The upper part of the Taiya River and the Nourse River join near the head of a 14-kilometer- $(\mathrm{km})$ long main stem valley, and West Creek, a major tributary, enters the Taiya River about $4.5 \mathrm{~km}$ from Taiya Inlet. Most of the main stem Taiya River valley bottom lies in the Chilkoot Trail Unit of Klondike Gold Rush National Historical Park (KLGO), founded in part to preserve and document culturally important artifacts and history from the 1897-98 Gold Rush and in part to foster understanding of the natural processes and species of this ecologically important corridor between coastal and interior Alaska. Recurrent proposals exploring the feasibility of a hydroelectric facility in the non-park headwaters of West Creek motivated this reconnaissance of the hydrology and geomorphology of the lower $7.5 \mathrm{~km}$ of the main stem Taiya River valley bottom and important hydrologically dependent resources of KLGO. The study conducted by the U.S. Geological Survey (USGS), in cooperation with the National Park Service, relied on a range of methods and data sources, including geomorphic mapping; review of historical surveys, aerial and ground photographs, and orthophotographs; lidar data; collection of suspendedsediment data; and published USGS streamflow and sediment data.

The Taiya River valley bottom owes its form to a suite of geologic processes, including faulting that set the general orientation of the valley, Pleistocene glacier occupation and retreat, and riverine processes that reworked the glacial outwash filling the valley bottom. Coastal influences include tidal estuarine processes and emergence of tidal surfaces uplifted by notably high rates of isostatic rebound from glacier retreat. Modern processes continuing to adjust the features of the valley bottom are a dynamic mix of fluvial processes, glacially controlled delivery of water and sediment, and uplift. As of 2019, the Taiya River was mostly contained in a single main channel with mid-channel or lateral bars except where a few sloughs convey a small part of the flow. However, in the Gold Rush era, the river sustained multiple paths and long, large sloughs, including the prominent West Branch Taiya River, which is now the abandoned Nelson Slough.

Similar streamflow seasonality and daily variations are expressed in records from the USGS streamgages for West Creek and the Taiya River. The similarity in streamflow patterns can be attributed to the similarity in basin characteristics and streamflow generating mechanisms between the basins. Streamflow in both the Taiya River and West Creek is strongly controlled by the presence of glaciers over 29 percent of each basin, which contributes to a prolonged summer high-flow season from May to October that peaks in late July or August and a winter low-flow season from November to April. The correlation between daily means for the two streams for the common period of record, 1970-77, was relatively high ( $r=$ $0.97)$ in the summer period and lower $(r=0.90)$ in the winter period. The two periods of USGS discharge record (1970-77 and 2004-17) for the Taiya River provided an opportunistic comparison, although the relatively short, discontinuous record challenges interpretations. Mean annual discharge increased slightly in the more recent period, and changes in the seasonal distribution of flow include a shift toward an earlier spring freshet and an increase in spring and early summer flow magnitude associated with snowmelt in the more recent period. No floods larger than the meteorologically driven flood of 1967 have occurred within the USGS discharge record, but historical accounts indicate at least one comparably sized flood in the mapping area between the Gold Rush and the start of streamgaging. 
Suspended sediment concentrations for six concurrent samples collected at USGS streamgages in water year 201718 ranged from 13 to 162 milligrams per liter ( $\mathrm{mg} / \mathrm{L}$ ) for West Creek and 6 to $284 \mathrm{mg} / \mathrm{L}$ for the Taiya River. The suspended sediment concentrations, relative to discharge, were slightly higher than historical values and consistent with seasonal and interannual variability common to glacial streams. The potential for future dynamic changes to the sediment supply of West Creek and the Nourse River is high, particularly for bedload sediment, considering the temporary impoundment of sediment stores in both basins by pro-glacial lakes. Significant morainal and tributary valley bottom sediment sources in the dynamically deglaciating headwaters of West Creek were partially released in the failure that generated the 2002 glacial lake outburst flood but as of 2019, these sources were restricted from West Creek by a likely ephemeral pro-glacial lake.

Within the mapping area, the valley bottom is dominated by surfaces containing suites of abandoned main stem channels and the large, low-angle West Creek fan. Channels of the Taiya River have often been abandoned intact when the river moves, such that individual channels can retain their shape for many decades, providing a conduit for flowing water or a low point for ponding. A total of 29 off-main-stem channels were detected from slope derivatives of lidar elevation data and cataloged by origin. An inventory of water conditions and surface-water sources for these off-main-stem channels shows that except for the small networks of channels on the West Creek fan, water is generally present at some location within abandoned channels. Groundwater and small tributaries form important water sources for these wetland habitats. National Park Service (NPS) amphibian monitoring sites are located in wetlands fed mostly by groundwater but occasionally inundated by main stem flow. One successful toad breeding site occurs in a brackish environment that is occasionally tidally inundated.

The Taiya River is dynamically adjusting to valleyscale geomorphic processes and local controls. Within the main stem valley bottom, the Taiya River flow paths were consolidated between 1894 and 1948 to a single path little moved since 1948, and the active channel belt was narrowed within that path. Glacial lake outburst floods documented in the historical period and as recently as 2002 in West Creek form a discrete disturbance mechanism that locally affected vegetation and channel patterns but has not fully reset channel patterns since at least the Gold Rush. The effects of pre-Gold Rush glacial lake outburst floods could not be completely determined for this study, but geomorphic evidence indicates there was an association with a period of increased channel activity that left channel scars throughout the valley. At the reach scale within the mapping area, the river has responded to tributary inputs and has migrated or reworked channel patterns in several locations. Multiple channel changes at the West Creek confluence since 1894 without significant fan growth have been the primary direct influence of West Creek on Taiya River. The extent of the West Creek fan indicates a historical and modern constraint of the Taiya River position. The large contribution of West Creek streamflow to the Taiya River affects fluvial activity downstream, increasing the ability of the channel to migrate or rework channels. Smaller tributaryfed channels have locally modified their paths within larger abandoned channels and contribute flow critical to anadromous streams. Locally significant channel migration resulting in bank erosion within about $1 \mathrm{~km}$ downstream of West Creek and as much as $300 \mathrm{~m}$ of meander migration and erosion at the Dyea townsite since 1918 have occurred as episodic pulses, such that within a single season banks can migrate tens of meters, but periods of bank stability can persist for decades. Ephemeral to persistent large woody debris jams provide a local control on channel location and migration. Beaver dams have deflected flow and generated widespread flooded areas persistent at a decadal scale, including a series of ponds along the Chilkoot Trail.

Monitoring approaches that focus on identifying the relative importance of groundwater losses from West Creek and the Taiya River to wetland water sources could facilitate understanding the drivers of wetland hydrology. Further characterizing the water sources for wetland habitats, including tributaries, groundwater closely connected to main stem river cycles, and groundwater disconnected from main stem river cycles, would improve the understanding of the range of likely effects from changes to those water sources. Continued monitoring of bank erosion could be supplemented with aerial photograph analysis to track local bank change. Records from ongoing monitoring of streamflow and turbidity could be periodically examined to identify future changes associated with dynamic glacial conditions in the West Creek and Taiya River Basins.

The fluvial history of the Taiya River and the geomorphic processes and hydrology of the valley bottom provide a context and basis for approaching a range of KLGO management challenges, including constraints on and patterns of channel migration, sensitive recreational seasons, and formative processes of and water sources for off-main-stem wetland habitats. An understanding of the hydrologic dependence of park resources enables efficient park planning, monitoring, and response to natural or human-initiated changes in delivery of sediment and water. 


\section{References Cited}

Alaska Boundary Tribunal, 1904, Sheet no. 17, in Atlas of award, Twenty-five sectional maps and index map showing the line fixed by the tribunal, Government Printing Office, Washington, accessed August 22, 2018, at https://www. davidrumsey.com/luna/servlet/view/all?sort=Pub_List_No_ InitialSort\%2CPub_Date\%2CPub_List_No\%2CSeries_No.

Alaska Department of Fish and Game, 2015, 2015 Alaska Wildlife Action Plan: Alaska Department of Fish and Game, Juneau, 228 p., accessed August 15, 2018 at http://www. adfg.alaska.gov/index.cfm?adfg=species.wapview.

Alaska Department of Transportation and Public Facilities, 1988, West Creek general layout and abutment and pier: Alaska Department of Transportation and Public Facilities.

Alaska Department of Transportation and Public Facilities, 2010, Structure inventory and appraisal sheet —Bridge 0309: Alaska Department of Transportation and Public Facilities.

Alaska Department of Transportation and Public Facilities, 2012, Structure inventory and appraisal sheet—Bridge 1490: Alaska Department of Transportation and Public Facilities.

Alaska Power Company, 2014, Application for preliminary permit, West Creek Hydroelectric Project: Federal Energy Regulatory Commission Docket P-14603, Accession Number 20140317-5039, 19 p, accessed January 12, 2016, at http://elibrary.ferc.gov/idmws/file_list.asp?document_ id $=14195117$.

Anderson, S.W., and Konrad, C.P., 2019, Downstream-propagating channel responses to decadal-scale climate variability in a glaciated river basin: Journal of Geophysical Research, Earth Surface, v. 124, no. 4, p. 902-919, accessed April 15, 2019, at https://doi.org/10.1029/2018JF004734.

Arimitsu, M.L., Litzow, M.A., Piatt, J.F., Robards, M.D., Abookire, A.A., and Drew, G.S., 2003, Inventory of marine and estuarine fishes in southeast and central Alaska National Parks: U.S. Geological Survey and National Park Service, Alaska Region Inventory and Monitoring Program Final Report, 79 p., accessed September 24, 2018, at https://www. nps.gov/sitk/learn/nature/upload/Arimitsu_etal_Fish_Inventory_Final_Jun_03.pdf.

Beck, R.W., and Associates, Inc., 1982, Haines-Skagway region feasibility study: Prepared for Alaska Power Authority, Anchorage, Alaska.

Beirely, A., 1917, Andrew Beirely collection photograph DO-24-1917: National Park Service Klondike Gold Rush National Historical Park, Skagway, Alaska.
Bernatz, G.C., Robertson, A.G., and Drazkowski, B.W., 2011, Klondike Gold Rush National Historical Park Natural Resource Condition Assessment: National Park Service Natural Resource Report NPS/NRPC/WRD/NRR—2011/288, 238 p., accessed September 7, 2018, at https://irma.nps.gov/ DataStore/Reference/Profile/2167556.

Boning, C.W., 1972, Floods of September 15, in the Lynn Canal area of southeastern Alaska, in Rostvedt, J.O., and others, eds., Summary of floods in the United States during 1967: U.S. Geological Survey Water-Supply Paper 1880-C, p. 89-93, accessed September 7, 2018, at https://pubs.usgs. gov/wsp/1880c/report.pdf.

Bosworth, K., 2000, Wetlands of the Dyea area of the lower Taiya River valley: Klondike Gold Rush National Historic Park, Skagway, Alaska, National Park Service, 100 p.

Buzzell, R.G., 2004, A history of the Skagway River: Alaska Department of Natural Resources Office of History and Archaeology Report No. 99, 34 p., accessed August 9, 2018, at http://dnr.alaska.gov/mlw/nav/naar/skagwayriver/skagway_river_nav_report_pdf_revised_2012.pdf.

Carpenter, K.D., Czuba, C.R., Magirl, C.S., Marineau, M.D., Sobieszcyk, S., Czuba, J.A., and Keith, M.K., 2012, Geomorphic setting, aquatic habitat, and waterquality conditions of the Molalla River, Oregon, 2009-10: U.S. Geological Survey Scientific Investigations Report 2012-5017, 78 p. [Also available at https://doi.org/10.3133/ sir20125017.]

Capps, D.L., 2004, Geohazards of the Taiya watershed, Klondike Gold Rush National Historical Park: National Park Service, $98 \mathrm{p}$.

Curran, J.H., 2020, Geomorphic surface and channel boundaries for the lower 7.5 kilometers of the Taiya River Valley, southeast Alaska, 2018: U.S. Geological Survey data release, https://doi.org/10.5066/P9XP1SE7.

Curran, J.H., Barth, N.A., Veilleux, A.G., and Ourso, R.T., 2016, Estimating flood magnitude and frequency at gaged and ungaged sites on streams in Alaska and conterminous basins in Canada, based on data through water year 2012: U.S. Geological Survey Scientific Investigations Report 2016-5024, 47 p., accessed July 19, 2018, at https://doi. org/10.3133/sir20165024.

Denton, C., Standley, L., and Lewis, B., 2005, A field investigation of glacial lake outburst potential in the Taiya River watershed: Skagway, Alaska, Bureau of Land Management Alaska Open File Report, 12 p.

Denton, C., Lewis, B., and Fisk, G., 2009, A geophysical investigation of glacial lake outburst potential of Nourse Moraine, Taiya River Watershed, Skagway, Alaska: Bureau of Land Management Alaska Open File Report 123, 11 p. 
Edwards, T.K., and Glysson, G.D., 1999, Field methods for measurement of fluvial sediment: Techniques of WaterResources Investigations of the U.S. Geological Survey, book 3, chap. C2, accessed July 17, 2018, at https://pubs. usgs.gov/twri/twri3-c2/.

Gehrels, G.E., 2000, Reconnaissance geology and U-Pb geochronology of the western flank of the Coast Mountains between Juneau and Skagway, southeastern Alaska, in Stowell, H.H., and McClelland, W.C., eds., Tectonics of the Coast Mountains, Southeastern Alaska and British Columbia-Boulder, Colorado: Geological Society of America Special Paper 343, p. 213-233.

Gibson, W., 2009, Mean precipitation for Alaska 1971-2000: National Park Service, Alaska Regional Office, Geospatial Dataset-2170508, accessed September 11, 2018, at https:// irma.nps.gov/DataStore/Reference/Profile/2170508.

Gurcke, K., 2010, The Stone House Flood: Alaska Geographic History Talks transcript, $4 \mathrm{p}$.

Hood, E., Eckert, G., Nagorski, S., and Talus, C., 2006, Assessment of coastal water resources and watershed conditions at Klondike Gold Rush National Historical Park, Alaska: National Park Service Water Resources Division Technical Report NPS/NRWRD/NRTR-2006/349, 89 p., accessed September 11, 2018 at https://irma.nps.gov/DataStore/Reference/Profile/659925.

Inglis, R., and Pranger, H., 2002, Trip and technical reportMay 6-10, 2002, Site Visit-Erosion of historic Dyea Townsite by Taiya River-Klondike Gold Rush National Historical Park (KLGO): National Park Service Memorandum, 19 p.

Jaeger, K.L., Curran, C.A., Anderson, S.W., Morris, S.T., Moran, P.W., and Reams, K.A., 2017, Suspended sediment, turbidity, and stream water temperature in the Sauk River Basin, Washington, water years 2012-16: U.S. Geological Survey Scientific Investigations Report 2017-5113, 47 p. [Also available at https://doi.org/10.3133/sir20175113.]

James, L.A., 1991, Incision and morphologic evolution of an alluvial channel recovering from hydraulic mining sediment: Geological Society of America Bulletin, v. 103, no. 6, p. 723-736.

Jones, J.L., 2006, Side channel mapping and fish habitat suitability analysis using LIDAR topography and orthophotography: Photogrammetric Engineering and Remote Sensing, v. 71, no. 11, p. 1202-1206, accessed September 11, 2018, at https://wa.water.usgs.gov/projects/dosewallips/data/ PE_RS_highlight.pdf.

Juracek, K.E., and Fitzpatrick, F.A., 2009, Geomorphic applications of stream-gage information: River Research and Applications, v. 25, no. 3, p. 329-347, accessed April 15, 2019, at https://doi.org/10.1002/rra.1163.
Kaufman, D.S., Young, N.E., Briner, J.P., and Manley, W.F., 2011, Alaska palaeo-glacier atlas (version 2), in Ehlers, J., Gibbard, P.L., and Hughes, P.D., eds., Developments in quaternary science: Amsterdam, The Netherlands, v. 15, p. 427-445, accessed September 18, 2018, at doi:10.1016/ B978-0-444-53447-7.00033-7.

Larsen, C.F., Motyka, R.J., Freymueller, J.T., Echelmeyer, K.A., and Ivins, E.R., 2005, Rapid viscoelastic uplift in southeast Alaska caused by post-Little Ice Age glacial retreat: Earth and Planetary Science Letters, v. 237, no. 3-4, p. $548-560$.

McArthur, J.J., 1894, International Boundary Commission photographs 99 and 100: Library and Archives Canada PA-162918-19.

Municipality of Skagway, 2009, Municipality of Skagway Multi-Hazard Mitigation Plan: Municipality of Skagway, Alaska, accessed October 2, 2018, at https://www.skagway.org/sites/default/files/fileattachments/community/ page/28411/multi-hazard_mitigation_plan.pdf.

Municipality of Skagway, 2014, Municipality of Skagway West Creek master plan: Municipality of Skagway, Alaska, Skagway Ordinance No. 14-09, 50 p., 1 app.

National Park Service, 2017, Nationwide rivers inventory: National Park Service, web, accessed June 27, 2017, at https://www.nps.gov/ncrc/programs/rtca/nri/index.html.

Neal, E.G., and Host, R.H., 1999, Hydrology, geomorphology, and flood profiles of the Mendenhall River, Juneau, Alaska: U.S. Geological Survey Water Resources Investigations Report 99-4150, 35 p., accessed July 3, 2019, at https:// pubs.usgs.gov/wri/1999/4150/1999_wrir99-4150.pdf.

Olson, P.L., Legg, N.T., Abbe, T.B., Reinhart, M.A., and Radloff, J.K., 2014, A methodology for delineating planninglevel channel migration zones: Washington Department of Ecology, Publication No. 14-16-025, 71 p., accessed July 8, 2019, at https://fortress.wa.gov/ecy/publications/documents/1406025.pdf.

Paustian, S.J., Trull, S.J., Foster, R.A., Atwood, N.D., Krieckhaus, B.J., and Rickers, J.R., 1994, Ecological inventory of Klondike Gold Rush National Historical Park and adjacent National Forest lands: U.S. Department of Agriculture Forest Service, Alaska Region technical report R10-TP-48, 108 p. plus appendixes, accessed July 18, 2018, at https://irma. nps.gov/DataStore/DownloadFile/428346.

Post, A., and Mayo, L.R., 1971, Glacier dammed lakes and outburst floods in Alaska: U.S. Geological Survey Hydrologic Investigations Atlas HA-455, 10 p., 13 plates, accessed August 31, 2018, at https://pubs.usgs.gov/ha/455/ report.pdf. 
Quantum Spatial, Inc., 2017, Chilkoot Trail and White Pass Lidar Reprocessing: National Park Service, Project 2271787, accessed February 6, 2020, at https:/irma.nps. gov/DataStore/Reference/Profile/2271787.

Rantz, S.E., and others, 1982, Measurement and computation of streamflow-Volume 1. measurement of stage and discharge; Volume 2. computation of discharge: U.S. Geological Survey Water-Supply Paper 2175, 631 p.

Richards, J., Jones, S., Mog, C., and Rockwell, H., 2017, Taiya riverbank erosion monitoring project-Dyea Townsite: Skagway, Alaska, National Park Service, 28 p.

Sacramento Daily Union, 1897, The avalanche at sheep camp: Sacramento Daily Union, v. 94, no. 36, p. 1, accessed August 3, 2018, at https://cdnc.ucr.edu/cgi-bin/ cdnc? $\mathrm{a}=\mathrm{d} \& \mathrm{~d}=\mathrm{SDU} 18970926.2 .2$.

Sergeant, C.J., and Johnson, W.F., 2018, Southeast Alaska Network freshwater water quality monitoring program-2017 annual report: National Park Service Natural Resource Data Series NPS/SEAN/NRDS—2018/1144, Fort Collins, Colorado, 24 p., accessed January 18, 2018, at https://irma.nps. gov/DataStore/DownloadFile/595339.

Slater, L., Singer, M., and Kirchner, J., 2015, Hydrologic versus geomorphic drivers of trends in flood hazard: Geophysical Research Letters, v. 42, no. 2, p. 370-376, accessed April 15, 2019, at https://doi.org/10.1002/2014GL062482.

Smelser, M.G., and Schmidt, J.C., 1998, An assessment methodology for determining historical changes in mountain streams: US Department of Agriculture, Forest Service, Rocky Mountain Research Station, General Technical Report RMRS-GTR-6, 29 p., accessed April 15, 2019, at https://www.fs.fed.us/rm/pubs/rmrs_gtr006.pdf.
Streveler, G., 1995, Behavior of the Nourse River system and its influence on the Taiya valley, summary of reconnaissance as of August, 1995: National Park Service informal report, $6 \mathrm{p}$.

Surdyk, S., and Waldo, A., 2018, Amphibian surveys at Klondike Gold Rush NHP2017 Summary: National Park Service Natural Resource Report NPS/KLGO/NRR, 80 p., accessed September 24, 2018, at https://irma.nps.gov/DataStore/ DownloadFile/598369.

The Seattle Post-Intelligencer, 1897, Scene of the Sheep Camp Disaster: The Seattle Post-Intelligencer, September 27, 1987, p. 2, accessed August 3, 2018, at https://chroniclingamerica.loc.gov/lccn/sn83045604/1897-09-27/ed-1/seq-2/.

U.S. Fish and Wildlife Service, 2017, Species status assessment report for the Eastern population of the boreal toad (Anaxyrus boreas boreas): U.S. Fish and Wildlife Service, accessed September 24, 2018, at https://www.fws. gov/mountain-prairie/es/species/amphibians/borealtoad/ Boreal\%20toad\%20SSA\%20Report\%20(1).pdf.

U.S. Geological Survey, 2018, U.S. Geological Survey water data for Alaska: U.S. Geological Survey National Water Information System, accessed July 17, 2018, at https:// nwis.waterdata.usgs.gov/ak/nwis/. [Also available at http:// dx.doi.org/10.5066/F7P55KJN.]

U.S. Geological Survey and U.S. Department of Agriculture, Natural Resources Conservation Service, 2013, Federal standards and procedures for the National Watershed Boundary Dataset (WBD) (4th ed.): Techniques and Methods, book 11, chap. A3, 63 p., https://pubs.usgs.gov/tm/11/ $\mathrm{a} 3 /$.

Wilson, F.H., Hults, C.P., Mull, C.G., and Karl, S.M., comps., 2015, Geologic map of Alaska: U.S. Geological Survey Scientific Investigations Map 3340, pamphlet 196 p., 2 sheets, scale 1:1,584,000 [Also available at http://dx.doi. org $/ 10.3133 / \operatorname{sim} 3340$. 


\section{Appendix 1. Geographic Information System Digital Files}

Digital files that accompany this report are available as a data release (Curran, 2020; https://doi.org/10.5066/P9XP1SE7). These include (1) polygons of geomorphic surfaces in the mapping area, (2) polygons of off-main-stem channels in the mapping area, and (3) metadata for the respective polygon files. 

Publishing support provided by the U.S. Geological Survey Science Publishing Network, Tacoma Publishing Service Center

For more information concerning the research in this report, contact the Director, Alaska Science Center

U.S. Geological Survey

4210 University Drive

Anchorage, Alaska 99508

https://www.usgs.gov/centers/asc/ 
